\title{
An assessment of impacts of Mute Swans (Cygnus olor) on submerged aquatic vegetation (SAV) in Chesapeake Bay, Maryland
}

\author{
Ketan Shrikant Tatu \\ West Virginia University
}

Follow this and additional works at: https://researchrepository.wvu.edu/etd

\section{Recommended Citation}

Tatu, Ketan Shrikant, "An assessment of impacts of Mute Swans (Cygnus olor) on submerged aquatic vegetation (SAV) in Chesapeake Bay, Maryland" (2006). Graduate Theses, Dissertations, and Problem Reports. 2490.

https://researchrepository.wvu.edu/etd/2490

This Dissertation is protected by copyright and/or related rights. It has been brought to you by the The Research Repository @ WVU with permission from the rights-holder(s). You are free to use this Dissertation in any way that is permitted by the copyright and related rights legislation that applies to your use. For other uses you must obtain permission from the rights-holder(s) directly, unless additional rights are indicated by a Creative Commons license in the record and/ or on the work itself. This Dissertation has been accepted for inclusion in WVU Graduate Theses, Dissertations, and Problem Reports collection by an authorized administrator of The Research Repository @ WVU.

For more information, please contact researchrepository@mail.wvu.edu. 


\title{
An Assessment of Impacts of Mute Swans (Cygnus olor) on Submerged Aquatic Vegetation (SAV) in Chesapeake Bay, Maryland
}

\author{
Ketan Shrikant Tatu
}

Dissertation submitted to the Davis College of Agriculture, Forestry and Consumer Sciences at West Virginia University in partial fulfillment of the requirements for the degree of

\author{
Doctor of Philosophy \\ in
}

Forest Resources Science

\author{
James T. Anderson, Ph.D., Chair \\ Larry J. Hindman, M.S. \\ Hillar Klandorf, Ph.D. \\ James S. Rentch, Ph.D. \\ Petra Bohall Wood, Ph.D.
}

Division of Forestry and Natural Resources

\author{
Morgantown, West Virginia \\ 2006
}

Keywords: Chesapeake Bay, Cygnus olor, exclosure study, exotic species, feeding, focal sample, invasions, Mute Swan, Ruppia maritima, Submerged Aquatic Vegetation, SAV, time-activity budget, widgeon grass 


\title{
Abstract \\ An Assessment of Impacts of Mute Swan (Cygnus olor) on Submerged Aquatic Vegetation (SAV) In Chesapeake Bay, Maryland
}

\author{
Ketan S. Tatu
}

Mute Swans (Cygnus olor) contribute to the localized decline in Submerged Aquatic Vegetation (SAV) through foraging in the Chesapeake Bay, Maryland. I assessed intensity of feeding activity of 868 Mute Swans in non-breeding flocks and breeding pairs through focal sampling during 2003 and 2004. I also assessed SAV reduction due to Mute Swan herbivory by measuring difference in percent cover, shoot density, and canopy height among 2 year controls $(n=54), 2$ year exclosures $(n=54)$, and 1 year exclosures $(n=54)$ at 18 sites on the eastern shore during the same time period. Analyses of the time-activity budgets showed that feeding was the most predominant activity of Mute Swans. Mute Swans in flocks spent more time feeding than those in pairs and swans in larger flocks spent more time feeding than those in smaller flocks. Analyses also showed that Mute Swan herbivory caused reduction in percent cover, shoot density, and canopy height of SAV. At the end of the study, mean percent cover, shoot density, and canopy height in the controls were lower by $79 \%, 76 \%$, and $40 \%$ respectively as compared to those in 2-year exclosures. Percent cover, shoot density, and canopy height increased by $26 \%, 15 \%$, and $22 \%$ respectively between early and late seasons of SAV growth in exclosures, but decreased by $36 \%, 41 \%$, and $18 \%$ in the controls. Non-breeding flocks that mainly occupied shallow water caused considerable (i.e., $75 \%$ to $100 \%$ ) SAV reduction. On the contrary, breeding pairs mainly occupied moderate depth sites and caused less (i.e., $32 \%$ to $75 \%$ ) SAV reduction.

I developed set of statistical models and selected the best one using Akaike's Information Criterion and spatial models using Geographical Information Systems to predict the Bay-wide SAV decline under the influence of Mute Swan herbivory. The spatial models indicated that $43 \%$ of the total SAV area had beds of widgeon grass (Ruppia maritima) or eelgrass (Zostera marina) (or both) with higher (i.e., 40-100\%) cover and such area potentially faces intense grazing pressure by Mute Swans. Statistical modeling suggested that although Mute Swan herbivory is not the most important factor influencing bay-wide SAV decline, it certainly contributes to SAV in the Bay. Therefore Mute Swan impacts should be incorporated into a larger framework of SAV protection in the Chesapeake Bay.

As flocks (especially larger ones) are more detrimental to SAV as compared to paired Mute Swans, I recommend that emphasis primarily be placed on removing adult Mute Swans in flocks, and secondarily on pairs. Considering the goal of the Atlantic Flyway Council to reduce Mute Swan Population in the Atlantic Flyway from about 14,000 birds in 2002 to 3,000 birds by 2013, I suggest that population of Mute Swans in the Chesapeake Bay, Maryland should be reduced from 3,600 individuals in 2002 to 342 individuals by 2013 . 


\section{ACKNOWLEDGEMENTS}

I acknowledge the contribution of several persons whom made it possible for me to complete this dissertation. First of all, I extend sincere thanks to my major advisor and committee member, Dr. James T. Anderson for providing me an opportunity to work on this project as a graduate research assistant and work with him despite the fact that I belong to a country that is thousands of miles away from the US and has considerable cultural, academic, and professional difference. Under his patient, friendly, and expert supervision, I learned a lot despite the fact that I had earned one Ph.D. from my home country, India. I also thank encouraging members of my doctoral committee: Dr. Petra Wood, Dr. Hillar Klandorf, Dr. Jim Rentch, and Larry Hindman. I specifically acknowledge the help rendered by Larry Hindman, Waterfowl Project Manager, Maryland DNR and his colleagues, particularly Brent Evans, at Maryland DNR (Wildlife and Heritage Service), Cambridge, Maryland in conducting fieldwork and providing copies of important documents and secondary data despite their busy schedule. Funding for this work was provided by Federal Aid in Wildlife Restoration, grant-W-61-R to Maryland DNR and Maryland Migratory Game Bird Stamp Funds. Thanks to U.S. Fish and Wildlife Service and Maryland DNR for funding and resources.

I am greatly indebted to Dr. George Seidel, who persistently provided statistical inputs and guidance. Without his timely help in data analyses, from the beginning to the end of my work, I could not complete important chapters of my dissertation.

I wish to emphasize all the vital help that was provided by Joseph Osbourne for my daunting fieldwork in waters of the Bay. He accompanied and helped me zealously in the Chesapeake Bay, sometimes in chilly winds of early winter and sometimes in the 
scorching heat of late summer. I also thank my interns Jonathan Chandler, Troy Osborne, and Andrew Isner for their assistance in varied tasks of my field work.

I am also thankful to Ann Anderson and colleague graduate students, especially Jason Love and Jennifer Edalgo for their ever-friendly interactions. They made me feel less 'exotic' while working thousands of miles away from my home country.

Thanks to Dr. Michael Strager for his timely help at a critical stage of GIS modeling and to Mike Henderson and WV GIS Technical Center for the GIS related technical assistance. Thanks to faculty and staff of the Division of Forestry and Natural Resources, West Virginia University. I am also grateful to David Wilcox (Virginia Institute of Marine Sciences) and Betsy Gardner (National Oceanic and Atmospheric Administration) for providing GIS data pertaining to the Chesapeake Bay.

I have no words to thank my wife Dr. Amita who came here from our home country during the critical period of dissertation writing. She not only provided moral and emotional support in consistently writing and revising chapters of my dissertation, but also contributed through ecological discussions and helping me in revising manuscripts. My son Avichal was a loving inspiration for me during this past year's work. I also thank my relatives here in the US for their help and support whenever required, and my father back in India to encourage my work despite his old age.

Thanks to my spiritual friend and mentor Arthur Coucouvitis at New York for providing moral and spiritual support.

How can I forget to thank Almighty God, Who I guess, was behind the success of this work despite my limitations! 


\section{TABLE OF CONTENTS}

CHAPTER I. LIST OF TABLES .......................................................ii

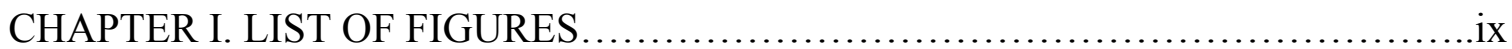

CHAPTER II. LIST OF TABLES......................................................

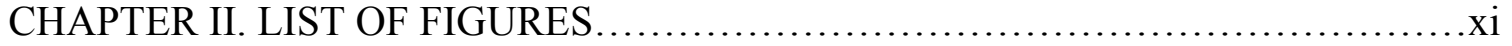

CHAPTER III. LIST OF TABLES .....................................................

CHAPTER III. LIST OF FIGURES..................................................

CHAPTER IV. LIST OF TABLES...............................................

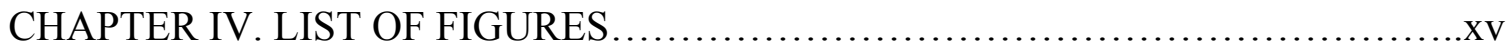

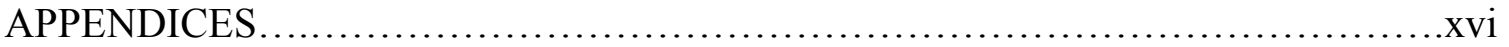

\section{CHAPTER I}

AN INTRODUCTION AND LITERATURE REVIEW OF MUTE SWANS AND SUBMERGED AQUATIC VEGETATION (SAV) IN

THE CHESAPEAKE BAY, MARYLAND........................................1

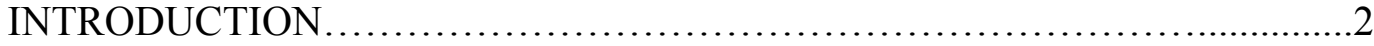

LITERATURE REVIEW...............................................

Ecological Impact of Mute Swans on SAV ...........................

Ecological Impact of Mute Swans on Native Waterfowl...................6

Mute Swan Control - A Controversial Issue............................. 8

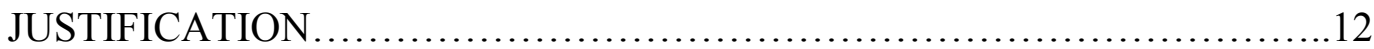

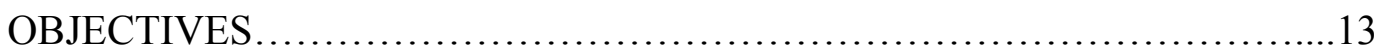

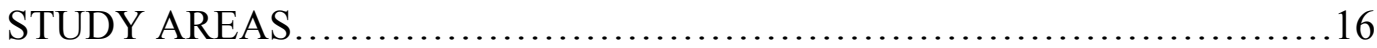

STUDY ORGANIZATION................................................... 18

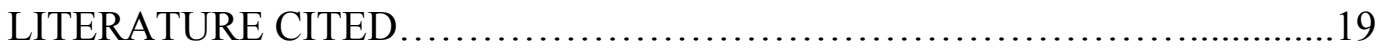

\section{CHAPTER II}

ASSESSMENT OF INTENSITY OF FEEDING ACTIVITY OF MUTE SWANS IN CHESAPEAKE BAY, MARYLAND USING TIME-

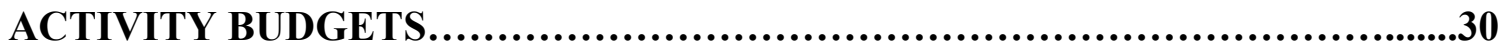

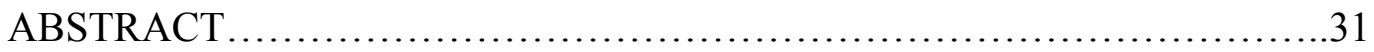

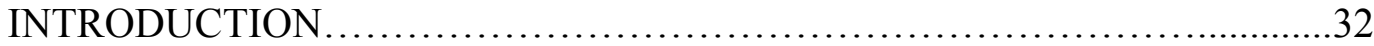

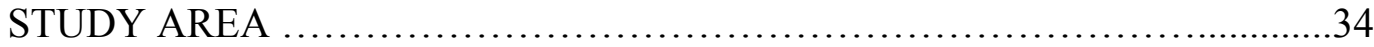

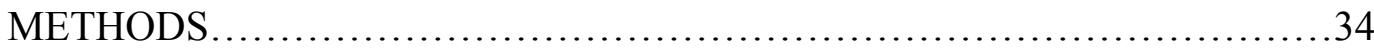

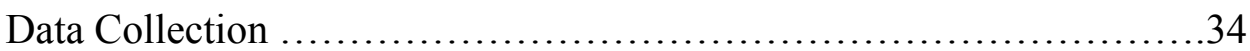

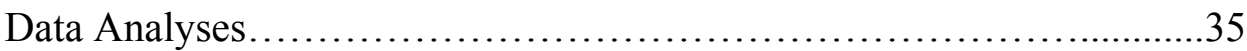

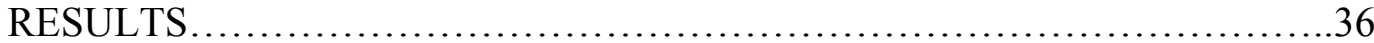

Overall Time Budget and Predominance of Feeding Activity..............37

Foraging Strategies................................................ 37

Agonistic Behavior while Feeding..................................... 38 


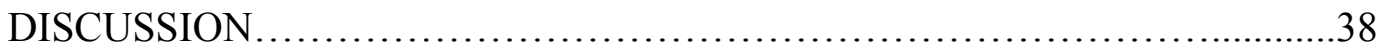

Overall Time Budget and Predominance of Feeding Activity...............38

Influence of Time Variations and Social Status............................40

Foraging Time of Pairs, Small Flocks, and Large Flocks.................42

Feeding Strategies...............................................43

Agonistic Activities..............................................45

MANAGEMENT IMPLICATIONS .......................................... 46

ACKNOWLEDGEMENTS ...................................................

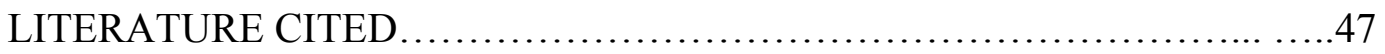

\section{CHAPTER III}

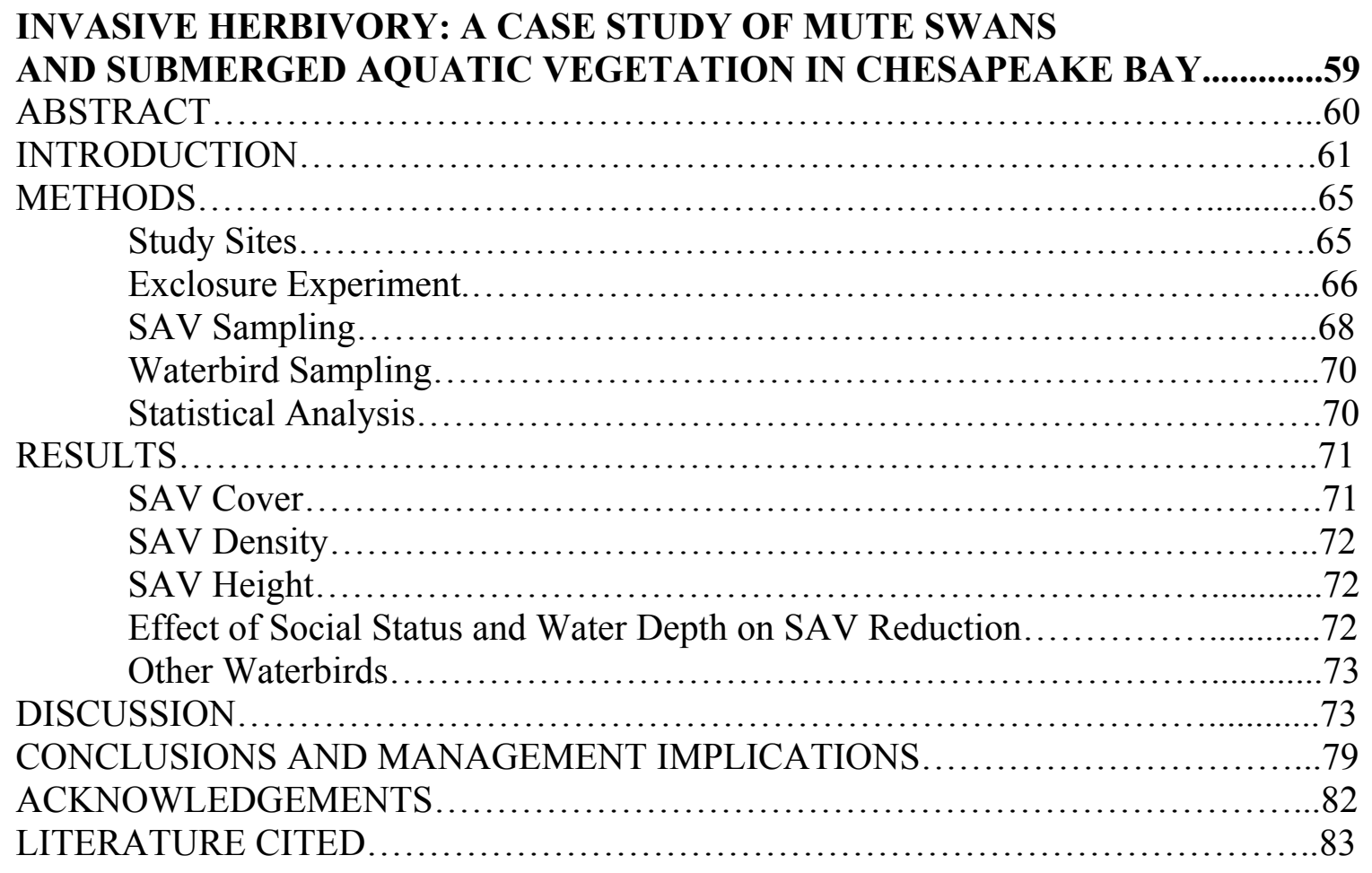

\section{CHAPTER IV}

\section{PREDICTIVE MODELING FOR SUBMERGED AQUATIC VEGETATION (SAV) DECLINE DUE TO MUTE SWANS IN}

THE CHESAPEAKE BAY ........................................................104

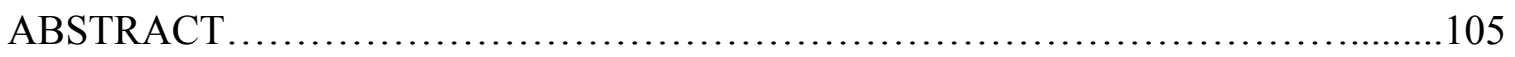

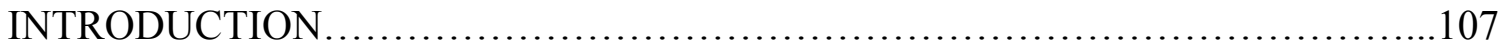

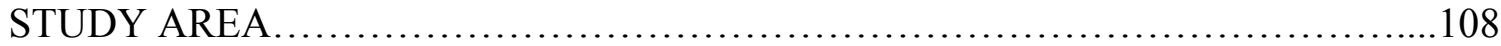

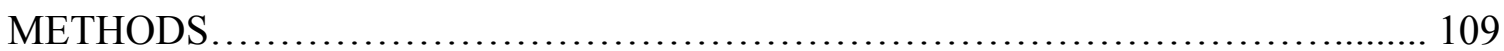

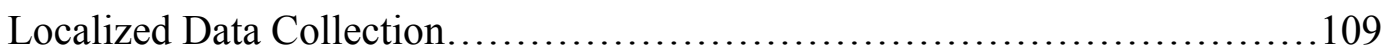

Statistical Model Development......................................... 110

Spatial Model Development...........................................111 


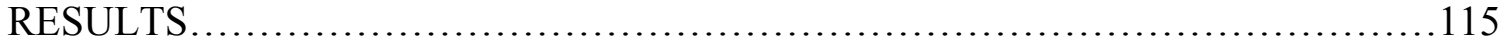

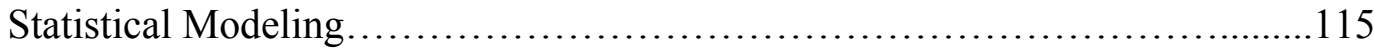

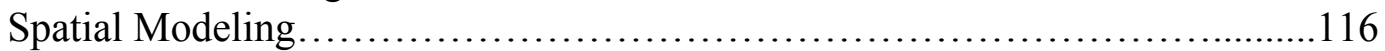

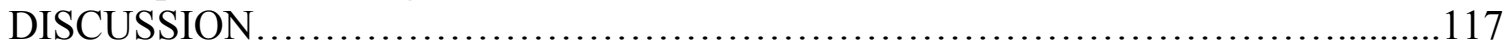

Statistical Modeling ................................................... 117

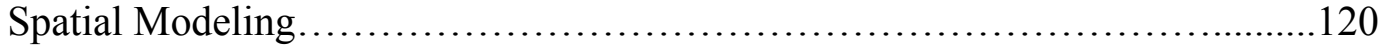

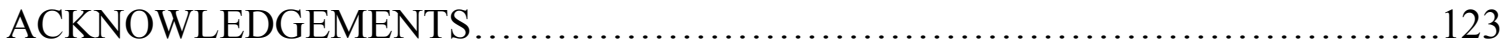

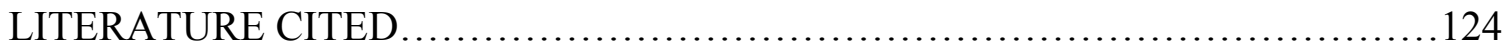

CHAPTER V

MANAGEMENT IMPLICATIONS AND FUTURE RESEARCH .................143

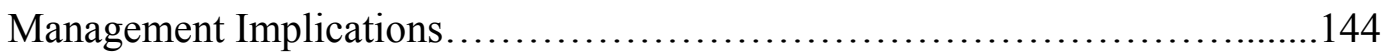

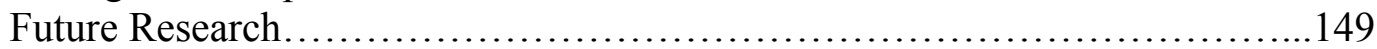

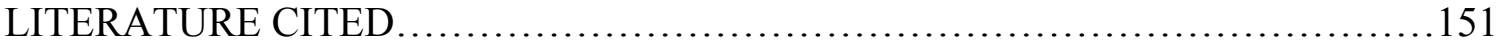

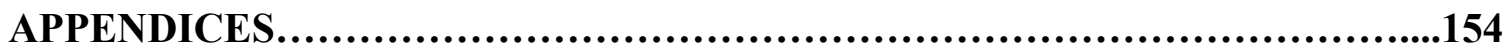




\section{CHAPTER I. LIST OF TABLES}

Table 1. County-wise population of Mute Swan in 2002 (Maryland DNR 2002)........25 


\section{CHAPTER I. LIST OF FIGURES}

Figure 1. Number of Mute Swans in Maryland, 1962-2002 (Maryland DNR

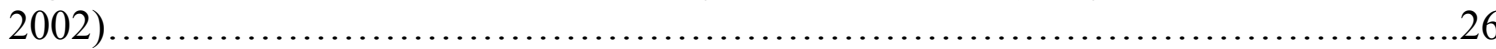

Figure 2. The distribution of Mute Swans in August-September 2002 (The

largest circle represents 472 swans)....

Figure 3. Location of Submerged Aquatic Vegetation (SAV) beds in the Chesapeake Bay in 2004, Virginia Institute of Marine Sciences (2004)....

Figure 4. Submerged Aquatic Vegetation (SAV) in the Chesapeake Bay, Maryland.

Figure 5. Widgeon grass (Ruppia maritima); the most abundant submerged aquatic plant species in the study area. 


\section{CHAPTER II. LIST OF TABLES}

Table 1. List of activities recorded for Mute Swan time-activity budgets at

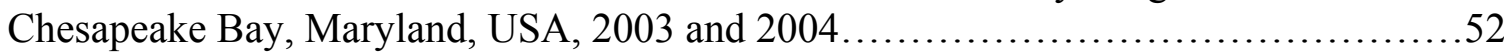

Table 2. Mean proportions and standard errors of diurnal time budgets by overall social status (i.e., pair and flock) for Mute Swans at Chesapeake Bay,

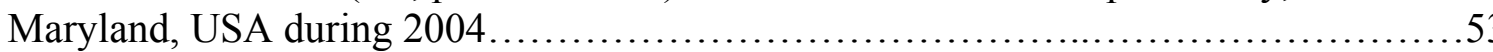




\section{CHAPTER II. LIST OF FIGURES}

Figure 1. Portions of Talbot and Dorchester Counties (marked) on eastern shore of Chesapeake Bay, Maryland, USA comprised study area for Mute Swan observations 2003 and 2004.

Figure 2. Comparative account of proportion of time spent in feeding and non-foraging activities of Mute Swans in Chesapeake Bay, Maryland, USA during $2003(\mathrm{~N}=50)$ and $2004(\mathrm{~N}=818)$ (Other = agonistic and disturbancerelated activities).

Figure 3. Proportion of time spent by Mute Swans in different feeding strategies at Chesapeake Bay, Maryland, USA during 2004. Time proportions with the same capital letter were not significantly different within feeding strategy type

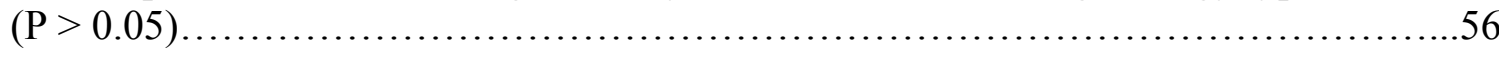

Figure 4. Feeding strategies of Mute Swans in the Chesapeake Bay...................57

Figure 5. Social affinities of Mute Swans while feeding in the Chesapeake Bay............58 


\section{CHAPTER III. LIST OF TABLES}

Table 1. The Daubenmire cover classes used to assess extent of substrate

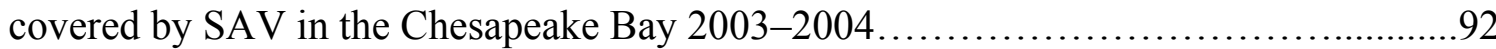

Table 2. Mean ( $\pm 1 \mathrm{SE})$ values of submerged aquatic vegetation characteristics in the sampling plots at study sites $(n=18)$ in Chesapeake Bay, Maryland at the end of the study (May 2003 - August 2004)...

Table 3. Water depth (m) classes, Mute Swan social status categories, and percent cover reduction of submerged aquatic vegetation (SAV) due to herbivory at study sites $(n=18)$, Chesapeake Bay, Maryland, May 2003 August 2004...

Table 4. Summary of waterbird species sharing study sites $(n=18)$ with Mute Swans during exclosure study on the Chesapeake Bay, Maryland, May 2003 August 2004. 


\section{CHAPTER III. LIST OF FIGURES}

Figure 1. Portions of Talbot and Dorchester Counties, Maryland (marked

with ovals) on the eastern shore of Chesapeake Bay wherein the sites $(n=18)$

for the submerged aquatic vegetation exclosures were located, 2003 and

2004

Figure 2. Lay out of sampling sub-plots $(1 \times 1 \mathrm{~m})$ in a sampling plot $(5 \times 5 \mathrm{~m})$

with core sub-plots marked with numbers ranging from 1 through 9 and diagonally located sub-plots $(3,5,7)$ used for submerged aquatic vegetation measurement marked in bold fonts, 2003 and 2004.

Figure 3. Mean percent cover, mean shoot density, and mean canopy height of submerged aquatic vegetation in the control and treatment plots in the Chesapeake Bay, Maryland, 2003 and 2004

Figure 4. Submerged aquatic vegetation percent cover (a), shoot density (b), and height (c) in the sampling plots from early to late growing season (2004) in the Chesapeake Bay, Maryland.

Figure 5. Mute Swan exclosure (under construction) in the Chesapeake Bay, Maryland.

Figure 6. Open plot (marked by a pole) at a study site in the Chesapeake Bay, Maryland.

Figure 7. Frames used for measuring submerged aquatic vegetation (SAV) in the Chesapeake Bay, Maryland...

Figure 8. Underwater measurement of submerged aquatic vegetation (SAV) at a study site in the Chesapeake Bay, Maryland 


\section{CHAPTER IV. LIST OF TABLES}

Table 1. Ranking of 15 a priori candidate models relating Submerged Aquatic Vegetation cover decline to predictor variables (water depth [WD], light penetration [LP], salinity [S], and Mute Swan population [SP]) for Chesapeake Bay, Maryland, 2003-04. Models were ranked using Akaike's Information

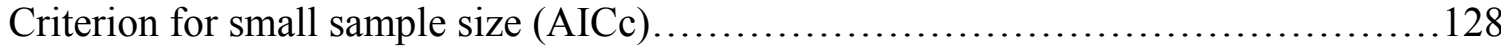

Table 2. Data layers used for spatial model development using ArcGIS 9...........130

Table 3. Localized data on Mute Swan population and other environmental variables used to predict the best approximating model for Submerged Aquatic Vegetation decline using information theoretic approach (Burnham and Anderson 1998) on the Chesapeake Bay, Maryland, 2003-04 


\section{CHAPTER IV. LIST OF FIGURES}

Figure 1. We conducted the Mute Swan-Submerged Aquatic Vegetation study on

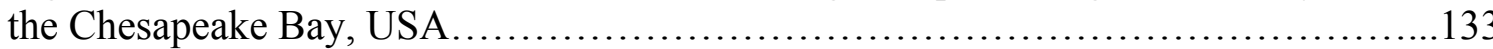

Figure 2. Portions of Talbot and Dorchester Counties, Maryland (marked) on the eastern shore of the Chesapeake Bay where 18 sites for data collections were located, 2003-04.

Figure 3. The data layer of Submerged Aquatic Vegetation (SAV) bed in the Chesapeake Bay that formed the basis for the GIS based modeling was down-loaded from the link (ftp://ftp.vims.edu/incoming/dwilcox/sav03 04.zip) provided by Virginia Institute of Marine Sciences (VIMS)

Figure 4. Bathymetry shape file of the Chesapeake Bay that was used to identify and depict 0 and $1 \mathrm{~m}$ contours was downloaded from the link (ftp://spo.nos.noaa.gov/public/wright/m130 grid.zip) provided by National Oceanic and Atmospheric Administration (NOAA) ..........................................136

Figure 5. A portion of northern Chesapeake Bay depicting proximity of $0 \mathrm{~m}$ and $1 \mathrm{~m}$ depth contours to Submerged Aquatic Vegetation (SAV) beds with the species that are potentially least consumed by Mute Swans

Figure 6. A portion of central Chesapeake Bay depicting proximity of $0 \mathrm{~m}$ and $1 \mathrm{~m}$ depth contours to Submerged Aquatic Vegetation (SAV) beds (with the species that are potentially most consumed by Mute Swans)

Figure 7. A portion of southern Chesapeake Bay depicting proximity of $0 \mathrm{~m}$ and $1 \mathrm{~m}$ depth contours to Submerged Aquatic Vegetation (SAV) beds (with the species that are potentially most consumed by Mute Swans).

Figure 8 . Beds with $40-100 \%$ cover of widgeon grass and eelgrass that potentially have highest threat from Mute Swan herbivory

Figure 9. Locations of large flocks of adult Mute Swans in the Chesapeake Bay (based on the survey conducted by Maryland DNR in September 2005)

Figure 10. 'Urgent protection SAV areas' (identified based on presence of large flocks of adult Mute Swans during the latest Mute Swan survey in September 2005) 


\section{LIST OF APPENDICES}

Appendix I. Mean ( \pm 1 SE) values of Submerged Aquatic Vegetation characteristics in the sampling plots at study sites in Chesapeake Bay,

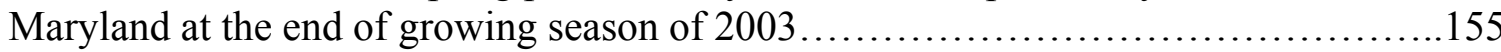

Appendix II. Percent cover of Submerged Aquatic Vegetation species at study sites $(n=18)$, Chesapeake Bay, Maryland, USA at the end of the study (May 2003-August 2004)....

Appendix III. Procedures in ArcGIS 9.0 that were carried out for spatial modeling.

Appendix IV. Determination of target population of Mute Swans in the Chesapeake Bay, Maryland by 2013..... 


\section{CHAPTER I}

AN INTRODUCTION AND LITERATURE REVIEW OF MUTE SWANS AND SUBMERGED AQUATIC VEGETATION (SAV) IN THE CHESAPEAKE BAY, MARYLAND

KETAN S. TATU

ktatu@mix.wvu.edu

West Virginia University

Division of Forestry

P. O. Box 6125

Morgantown, WV 26506-6125 


\section{INTRODUCTION}

Chesapeake Bay, the largest estuary $\left(11,500 \mathrm{~km}^{2}\right)$ of the conterminous United States, located in Delaware, Maryland, and Virginia is a major coastal habitat for native waterfowl of North America (Hindman and Stotts 1989). The Bay formed by over 150 rivers and streams and tidal waters of the Atlantic Ocean is one of the primary waterfowl wintering areas in the Atlantic Flyway that supports $40 \%$ of the wintering waterfowl in the Flyway (Hindman and Stotts 1989, Meyers et al. 1995). Different species of dabbling ducks like Mallard (Anas platyrhinchos) and American Black Duck (A. rubripes), diving ducks like Canvasback (Aythya valisneria) and Lesser Scaup (A. affinis), Tundra Swan (Cygnus columbianus), mergansers, sea-ducks and Canada Geese (Branta canadensis) use the Bay for wintering or as migratory stopover sites (Hindman and Stotts 1989).

Though Chesapeake Bay traditionally has played a vital role in providing habitat to wintering native waterfowl, it is inhabited by thousands of individuals of a resident exotic waterfowl species since the 1990s. Mute Swans (Cygnus olor), which are exotic to the United States and exist in the Atlantic Flyway since 1910 (Atlantic Flyway Council 2003) have undergone phenomenal population growth in the Chesapeake Bay, especially in the portion of the Bay located in Maryland (Ciaranca et al. 1997, Perry et al. 2004, Hindman and Harvey 2004). Mute Swans in this area are attributed to 5 swans that escaped captivity in 1962 (Reese 1980). Their numbers have increased from 5 individuals in 1962 to 3,624 individuals in 2002 (Hindman and Harvey 2004). Though their population grew slowly for two decades after accidental introduction in 1962 (Reese 1975), the swan population underwent dramatic growth after the mid-1980s (Hindman and Harvey 2004). The problem of a dramatic population rise of Mute Swans is aggravated by their strong preference for Submerged Aquatic Vegetation (SAV) which 
leads to overgrazing (Allin 1981, Ciaranca et al. 1997, Perry et al. 2004, Hindman and Harvey 2004). Moreover, some pairs are aggressive towards native waterbirds. Their aggressiveness had resulted in the abandonment of nesting colonies of Black Skimmers (Rynchops niger) and Least Terns (Sterna antilarum), and Common Terns (Sterna hereundo) at Barren Islands in the early 1990s (Therres and Brinker 2004). They also compete with native, wintering Tundra Swans, especially for shelter (Hindman and Harvey 2004). Such problems created by Mute Swans in the Chesapeake Bay have raised serious concern to a point where Maryland Department of Natural Resources (Maryland DNR) planned to reduce Mute Swan population to less than 500 birds that existed during the early 1980s (Hindman and Harvey 2004).

This study will assess types and magnitude of impacts of Mute Swans on SAV in different localities of the Chesapeake Bay (Maryland), and based on these findings, it will attempt to infer the Bay-wide impacts of Mute Swans. The assessment mainly will be done through evaluation of species richness, percent cover, height, and density of the submerged aquatic plants in fenced and open plots, and through determining time activity budget of breeding and molting Mute Swans. In addition, this study also will evaluate the impact of Mute Swans on native waterfowl occurring in the Chesapeake Bay. The research should provide valuable insight into the magnitude of Mute Swans' impacts on $\mathrm{SAV}$, and in turn, help in restoration and management of SAV in the Chesapeake Bay.

\section{LITERATURE REVIEW}

The most recent research on Mute Swans in the Chesapeake Bay has focused on seasonal movements and habitat associations of Mute Swans in the Bay and their aggression towards Tundra Swans (Sousa 2005). However, published literature regarding 
Mute Swans in the Chesapeake Bay (Maryland) is meager (Mike Naylor, Maryland DNR, personal communication). The only comprehensive paper regarding Mute Swans in Maryland portion of the Bay is one by Hindman and Harvey (2004) in the proceedings of the symposium "Mute Swans and their Chesapeake Bay Habitats" (Perry 2004). As per the proceedings, population of Mute Swans increased at an annual rate of 23\% from 1986 to 1992 , and from 1993 to 1999 it increased at an annual rate of about 10\% (Hindman and Harvey 2004). The Bay population of Mute Swans increased by 1200\% from 1986 to 1999 and now represents 30\% of the total Atlantic Flyway Mute Swan population (Perry et al. 2004). During an aerial survey conducted by the Maryland DNR and the U.S. Fish \& Wildlife Service in 2002, 3,624 Mute Swans were counted (Table 1). As per the latest survey conducted in September 2005 (Larry Hindman, Maryland DNR, personal communication), a total of 2,224 Mute Swans (1,929 adults and 295 cygnets) were recorded in the Maryland portion of the Bay. The present day population of this exotic waterfowl is incompatible with native aquatic floral and faunal species. It also was anticipated that if not controlled effectively, the Mute Swan population may range from 13,500 to 38,000 individuals in 2010 (Hindman and Harvey 2004). If this projection becomes the reality, irreversible ecological damage may occur in the Bay in general, and to the SAV and native waterfowl in particular. Fortunately after many years of controversy and limited control (e.g. primarily egg oiling), Mute Swan control is again being implemented and it may play important role in preventing such damage.

\section{Ecological impact of Mute Swans on SAV}

Submerged aquatic vegetation refers to those vascular plants that live and grow completely underwater or just up to the water surface (Hurley 1990). It is a key 
component of the Chesapeake Bay ecosystem, which performs a number of valuable ecological roles in the Bay, such as: (1) constituting a major food source for native waterfowl; (2) providing habitat and shelter to a variety of fish, crabs, shellfish, and many small invertebrates; (3) contributing to chemical processes, such as nutrient absorption and oxygenation of water column; (4) baffling wave energy and slowing water currents; helping to maintain water clarity by reducing the amount of sediments suspended in water; and (5) preventing shoreline erosion; and absorbing nutrients such as phosphorus and nitrogen (Martin and Uhler 1951, Adams 1976, Orth and Heck 1980, Munro and Perry 1982, Hurley 1991). Such an important biotic component of the Bay had been under severe pressure since 1960, and well over half of the SAV had disappeared from the Bay by the 1980s (U.S. Fish and Wildlife Service 2003). Once thousands of hectares of SAV beds filled the Bay, but by 1984, they covered only about 15,385 ha (Blankenship 2003). Declining water quality, disturbance of SAV beds, and alteration of shallow water habitats have contributed to the SAV decline (Hurley 1990).

Though Mute Swans are probably not the principal factor affecting the SAV in the Bay, they are believed to contribute to the SAV decline and hamper SAV restoration activities (Hindman and Harvey 2004). This is because the submerged aquatic plants are the mainstay of their diet (Bellrose 1980, Perry et al. 2004). In 80 fecal samples collected between June 1977 and March 1979, the great majority of food identified (81.8\%) was submerged vascular vegetation (Fenwick 1983). Analysis of the gullet (esophagus and proventriculous) and gizzard of Mute Swans from the Chesapeake Bay has indicated that the species is primarily herbivorous during all seasons of the year and primarily feeds on SAV (Perry et al. 2004). Food volume in the gullets of swans averaged $84 \mathrm{ml}$ with a maximum of $130 \mathrm{ml}$ (Perry et al. 2004). An adult Mute Swan can reach SAV under 
water up to the depth of $1.07 \mathrm{~m}$ and can consume about $1.8 \mathrm{~kg}$ to $3.6 \mathrm{~kg}$ of plant material each day (Owen and Cadbury 1975, Fenwick 1983). Considering the total population of swans, it is estimated that the swans annually eat about 4.7 million $\mathrm{kg}$ of bay grasses (Hindman 2003).

In the Chesapeake Bay, widgeon grass (Ruppia maritima) constitutes $66 \%$ of the foods eaten at Eastern Bay, whereas Eelgrass (Zostera marina) forms $2 \%$ of the food eaten (Perry et al. 2004). In the Chesapeake Bay, Mute Swans also feed on sago pondweed (Stuckenia pectinata), horned pondweed (Zannichellia palustris) and Eurasian water-milfoil (Myrophyllum spicatum) (Hindman 1982, Fenwick 1983). Invertebrates (including bryozoans, shrimp, and amphipods) form a much smaller proportion of the food consumed (Perry et al. 2004). Mute Swans not only consume great quantities of the SAV, but in high concentrations, Mute Swans also can overgraze an area, especially, when water is shallow (Hindman and Harvey 2004). In extreme cases, the bottom substrate is left barren and cratered in appearance (New York Department of Environmental Conservation 1993).

\section{Ecological impacts of Mute Swans on native waterfowl}

The accidental and intentional introduction of the exotic waterfowl can have negative ecological impacts on native species and their habitats (Weller 1969). Mute Swans are no exception to this phenomenon. Breeding pairs are extremely aggressive and occupy and defend large territories (up to 6 ha) of wetland habitats during nesting, brood rearing, and foraging (Birkhead and Perrins 1986). Mute Swans are often aggressive while interacting with other native waterfowl, especially during the breeding season, when paired swans are highly territorial. Attacking, injuring, or killing other 
birds also has been reported (Reese 1975, Hindman and Harvey 2004, Therres and Brinker 2004). Molting swans have displaced native species from their breeding and feeding habitats. In the1990s, a molting flock of about 600-1,000 non-breeding Mute Swans excluded Black Skimmers, Least Terns, and Common Terns from using the oyster shell bars and beaches in the Tar Bay area (Dorchester County) for nesting sites (Hindman and Harvey 2004). Mute Swan pairs have been observed exhibiting aggression toward wintering Tundra Swans in Maryland, driving them from foraging areas and protected coves used for winter shelter (Hindman and Harvey 2004, Sousa 2005).

Apart from directly posing adverse effect on native waterfowl through aggression, Mute Swans also indirectly affect native birds by heavily grazing on SAV and uprooting submerged plant important as a food source for native waterfowl. Mute Swans graze at the surface of the water, but can upend in water up to $1.07 \mathrm{~m}$ deep to feed on SAV (Owen and Cadbury 1975). Moreover, adult Mute Swans tend to paddle and rake the substrate to dislodge SAV and invertebrates for them and their cygnets; thus, more SAV is destroyed and uprooted than is eaten (Petrie and Francis 2003). Overgrazing by Mute Swans adversely affects plant-based food availability for other native waterfowl that are either fully or partly herbivorous. Mute Swans increase their feeding rate during spring and summer, because more food is required before feather molt and egg-laying, which probably influences the availability of SAV to fall migrant waterfowl (Wilmore 1974, Petrie and Francis 2003). Significant reduction of SAV has been observed in small ponds used by breeding Mute Swan pairs (Chasko 1986). Heavy grazing of SAV by waterfowl during its growth and reproduction can reduce the reproductive success of these plants (Sondergaard et al. 1996, Bortolus et al. 1998) and reduces those macroinvertebrates that 
are dependent on these plants for food and shelter (Krull 1970, Voigts 1976, Whitman 1976, Engel 1990). Thus, it is likely that overgrazing by Mute Swans also can adversely affect waterfowl feeding on macroinvertebrates.

\section{Mute Swan control - a controversial issue}

During the 1990s, certain Maryland residents began voicing concerns about an increase in conflicts with Mute Swans due to their aggressive behavior. Citizens also began providing anecdotal complaints to the Maryland DNR that Mute Swans were overgrazing SAV in the Chesapeake Bay (Hindman and Harvey 2004, Markarian and Lovvorn 2004). They also reported that Mute Swans drive away wintering tundra swans from feeding areas and sheltered coves (Hindman and Harvey 2004). Based on the past studies conducted in the US and Europe on Mute Swans' diet and behavior (Wilmore 1974, Bellrose 1980, Fenwick 1983, Birkhead and Perrins 1986, Sondergaard et al. 1996, Bortolus et al. 1998) and their personal observations, some biologists in the United States also expressed their concern about the potential adverse impact of Mute Swans on the Chesapeake Bay ecosystem (Reese 1975, Hindman 1982, Fenwick 1983, Hindman 2002, Perry et al. 2004).

Concerned about the potential impact of Mute Swan herbivory in the Chesapeake Bay, in 2000, Maryland's Secretary of Natural Resources, Dr. Sarah Taylor Rogers, appointed a committee to review the species status and its ecological impacts and conflicts with humans, and develop management recommendations for the Mute Swans in early 2000s (Hindman 2003). Later, in 2001, the Maryland General Assembly directed

the Maryland DNR to establish a program to control the population of Mute Swans and to consider a regulated hunter harvest as a control method (Hindman and Harvey 2004). 
Further, Maryland DNR proposed a program to reduce the Mute Swan population in Maryland, to mid-1980s level (i.e., $<500$ swans) (Atlantic Flyway Council 2003) and aid in the restoration of SAV beds (Markarian and Lovvorn 2004). Until late 2001, Maryland DNR had the authority to allow the taking of swans (as wetland game birds) under the statutory definition of Wetland Game Birds (Hindman and Harvey 2004). State law also authorized the Maryland DNR to regulate possession, sale, trade, exportation, and importation of Mute Swans in Maryland (Hindman and Harvey 2004). This authority to regulate the take and possession of Mute Swans existed as the birds were not Federally protected by the U.S. Fish and Wildlife Service (USFWS) under the Migratory Bird Treaty Act (MBTA) owing to their exotic and nonmigratory status. However, on December 28, 2001 the U.S. Court of Appeals for the District of Columbia Circuit Court ruled that, as swans are members of the waterfowl family Anatidae, Mute Swans were protected by the MBTA. Thereafter, the Maryland General Assembly urged the USFWS to act with expediency to develop a regulatory process that would allow Maryland to establish a method of controlling the Mute Swan population and to mitigate the Mute Swan population's impact permanently (Hindman and Harvey 2004).

In March 2003, the Maryland DNR obtained a federal depredation permit from the USFWS to addle eggs in up to 350 nests and to euthanize 1,500 adult and sub-adult Mute Swans. However, like many exotic species, Mute Swans have a constituency that values them aesthetically and seeks to prevent harm to them (Delach et al. 2001). The constituency mainly comprised some residents of Maryland's Eastern Shore and The Fund for Animals, Friends of Animals, and the Humane Society of the United States. They opposed governmental and non-governmental organizations (i.e., USFWS, Maryland DNR, National Audubon Society, Chesapeake Bay Foundation, American Bird 
Conservancy, and The Nature Conservancy) that promoted or supported Mute Swan population control through a combination of lethal and non-lethal means. They and the residents suggested alternatives to lethal control of Mute Swans, but Maryland DNR insisted that only lethal control measures of Mute Swans would be sufficient for effective control.

This led the Fund for Animals and a group called "Save our Swans" (that was constituted of several residents of Maryland's Eastern Shore) to file a lawsuit in U.S. District Court for the District of Washington in May 2003 (Markarian and Lovvorn 2004). The case challenged a decision by the USFWS to issue a depredation permit under the MBTA to authorize the Maryland DNR to eliminate up to 1,500 Mute Swans in the state regardless of whether the conditions at any particular location actually meet the strict requirements for depredation under the international Conventions, the MBTA, and the USFWS's implementing regulations. The lawsuit also alleged that, by effectively issuing a permit to the Maryland DNR to euthanize up to 1,500 swans without preparing either an Environmental Impact Statement (EIS) or an Environmental Assessment (EA), the USFWS also violated the National Environmental Policy Act (NEPA), the Council of Environmental Quality's (CEQ) implementing regulations for NEPA, and the Administrative Procedure Act (APA). Three days after The Fund for Animals' suit was filed in May 2003, the Maryland DNR voluntarily surrendered its USFWS permit, and the USFWS announced that it would prepare an EA on its issuance of depredation permits for Mute Swans. In June 2003, the USFWS published a Draft Environmental Assessment for Managing Mute Swans in the Atlantic Flyway, proposing to allow states to reduce the Mute Swan population in the Atlantic Flyway and to maintain the population at lower levels. The EA determined that the reduction of the swan population 
would not have a significant environmental impact. Thus, the USFWS proposed to allow the States to initiate their proposed population reduction activities. In July 2003, the USFWS issued a new permit to the Maryland DNR authorizing the agency to euthanize up to 525 Mute Swans (Markarian and Lovvorn 2004). The Fund for Animals and other plaintiffs filed a second suit in August 2003, challenging the new EA and the USFWS's decision to immediately authorize states to conduct Mute Swan population control activities. The plaintiffs claimed that a full Environmental Impact Statement (EIS) was required and sought a preliminary injunction to preserve the status quo until such time as the court could resolve the merits of their claims. On September 9, 2003, U.S. District Judge Emmet G. Sullivan granted the preliminary injunction requested by The Fund for Animals halted all Mute Swan population control in the U.S. Judge Sullivan gave his decision that the Court will essentially speak for the Mute Swans. Consequently, the USFWS decided to cancel all permits to kill Mute Swans that it had issued, not just in Maryland, but throughout the U.S. More than 50 permits to state and local agencies were ultimately withdrawn. This occurred because the USFWS was unable to issue depredation permits without first complying with NEPA, the MBTA, and Judge Sullivan's order (Markarian and Lovvorn 2004).

In December 2003, U.S. Congressman Wayne Gilchrest (R-MD), Chairman of the House Subcommittee on Fisheries Conservation, Wildlife and Oceans, held an "Oversight Field Hearing on Exotic Bird Species and the MBTA." The hearing was held in Annapolis and was attended primarily by representatives of the USFWS, DNR, and a few environmental organizations (Markarian and Lovvorn 2004). In April 2004, he introduced the Migratory Bird Treaty Reform Act of 2004 into the House of Representatives. The purpose of the Act was to clarify that the provisions of the 
Migratory Bird Treaty Act (MBTA) of 1918 do not regulate human-introduced, nonnative birds. The MBTA is the domestic implementation legislation for four Migratory Bird Treaties (Canada, Mexico, Russia, and Japan) and provides protection for migratory birds in North America. The Migratory Bird Treaty Reform Act of 2004 passed and was signed by President Bush. Subsequently, the USFWS published a list of nonnative bird species that no longer are afforded Federal protection by MBTA. The Mute Swan is now regulated by state wildlife agencies (Maryland DNR 2005).

In Maryland, Mute Swan control resumed during the spring of 2005. DNR staff oiled more than 380 Mute Swan nests to reduce annual production (Larry Hindman, Maryland DNR, personal communication). Removal of adult Mute Swans by humane methods has resumed (Hindman et al. 2005).

\section{JUSTIFICATION}

Risks to the Chesapeake Bay (Maryland), due to the population explosion of exotic Mute Swans and the resulting impacts on SAV and native waterfowl are wellpublicized in Maryland. However, a comprehensive and quantitative ecological assessment has not been carried out to determine the cumulative effects of grazing Mute Swans on SAV in the Bay. Consequently, quantitative data on the reduction of SAV by Mute Swans in the Bay is limited (Hindman and Harvey 2004) and compels one to rely on observations from other areas of the world, which suggest that impacts of SAV decline can be serious and detrimental (Hindman and Harvey 2004, Perry et al. 2004). For example, in Europe Mute Swans have been known to completely remove individual plant species from some wetlands, eliminating this food source for other waterfowl that feed on the same SAV species (Gillham 1956, Jennings et al. 1961, Mathiasson 1973, 
Chairman 1977, Neirheus and Van Ireland 1978, Scott and Birkhead 1983). This study would facilitate such a comprehensive assessment. Moreover, it is inferred that when viewed from the Bay-wide perspective, the amount of SAV currently being consumed by the Mute Swan population in the Bay may be negligible. However, anecdotal reports and complaints received by the Maryland DNR suggest that Mute Swans reduce the quantity of SAV on a local level (Hindman and Harvey 2004). Despite this, quantitative data to support this inference are non-existent. This study will attempt to fill this important information gap regarding local level impacts of Mute Swans on the SAV. The database generated and insight developed by this study would form the base for determining and minimizing problems created by exotic Mute Swan in the Chesapeake Bay (Maryland). It is the consensus of the Chesapeake Bay Program SAV Task Group that continued expansion of the Mute Swan population runs counter to the Vital Habitat Protection and Restoration goal of the Chesapeake 2000 Agreement, in particular, the goal to "Preserve, protect, and restore those habitats and natural areas vital to the survival and diversity of the living resources of the Bay and its rivers (Maryland DNR 2002). The present study will help determine the impact of Mute Swans in relation to the habitat protection and restoration goals.

\section{OBJECTIVES}

The main purpose of this study is to assess impacts of Mute Swans on SAV, by evaluating the magnitude of SAV feeding by the swans and evaluating response of SAV to Mute Swan herbivory in different localities of the Chesapeake Bay (Maryland). This study will address the localized impacts of Mute Swans on SAV through in situ SAV measurements and determination of the time-activity budget of the swans in different 
localities of the Bay. The local-level findings will then be used to infer the characteristics/pattern and magnitude of impacts at the bay-wide level. This study also will attempt to assess the impact of the swans on native waterfowl in the Chesapeake Bay.

The specific objectives are:

1. To determine SAV species at different localities of the Bay where non-breeding flocks and breeding pairs of Mute Swans feed regularly;

2. To determine the impact of territorial pairs and non-breeding flocks of Mute Swans on abundance of SAV in different localities by determining percent cover and density in plots with and without Mute Swan foraging;

3. To determine the impact of territorial pairs and non-breeding flocks of Mute Swans on the canopy height of SAV (preferably species-wise) in different localities;

4. To infer bay-wide impact of Mute Swan based on localized findings using predictive modeling (statistical and spatial); and

5. To determine the time-activity budget of adult Mute Swans in nonbreeding flocks and those in breeding pairs through focal sampling.

I anticipate that Mute Swans, owing to their predominantly herbivorous diet, cause significant reduction in SAV. I hypothesize that at sites inhabited by Mute Swans, $\%$ cover, density, and canopy height of SAV will be comparatively more in the areas free from Mute Swan herbivory (e.g., in exclosed or fenced plots), than in the areas exposed to the herbivory (e.g., open or non-fenced plots). I also predict that SAV beds at the sites supporting flocks of Mute Swans are affected more than those supporting only pairs of swans. This is because, non-breeding flocks, being nomadic in their SAV 
utilization strategy, over-exploit SAV in a shorter time period at any site, whereas a breeding pair, after occupying a territory, being sure of long-term SAV availability and having only 2 adult individuals (with or without juveniles) consume SAV in a comparatively sustainable manner.

I anticipate that on average, the proportion of time spent foraging (determined from time-activity budget) by a swan in a breeding pair would be less than the proportion of time spent foraging by a swan in a non-breeding flock. This is because, a swan in a breeding pair has a 'secured' territory and in turn, secured food resources, not requiring its quick exploitation; whereas a swan in a flock does not have such food security, requiring rapid exploitation. Based on this premise, I hypothesize that on average, a Mute Swan in a breeding pair spends less time per day for feeding compared to an individual in a flock.

I also predict that the adverse effect of Mute Swan herbivory on SAV would be comparatively more at the sites with shallower waters than at those having deeper waters. This is because SAV in shallower water can be reached by Mute Swans with greater ease and in turn, can be accessed and consumed more easily by Mute Swans. In turn, SAV in shallower water would be consumed at a faster rate and/or to a greater extent by Mute Swans.

As such, the following null hypotheses will be tested:

1. At sites inhabited by Mute Swans in the Bay, percent cover, density, and canopy height of SAV are equal in the fenced plots (fenced for 1 or 2 growing season) and open (or non-fenced) plots;

2. Sites supporting non-breeding flocks and those supporting primarily breeding pairs have equal $\%$ cover and density of SAV; 
3. For feeding activity, proportion of total activity time spent (determined from time-activity budget) by an average swan in a breeding pair and an average swan in a non-breeding flock is equal; and

4. Depth of water does not affect the SAV-Mute Swan interaction.

\section{STUDY AREA}

The study area is located on the eastern shore of the Chesapeake Bay, Maryland. The Chesapeake Bay is a $288 \mathrm{~km}$ long and $8-48 \mathrm{~km}$ wide estuary, that runs in a northsouth direction, roughly parallel to the Atlantic seacoast (Lippson 1973, Lippson and Lippson 1984). The Bay lies within a temperate geographic zone with seasonal changes in water temperature of moderate extent. Seasonal temperature cycles influence the activity rhythm of the biota inhabiting it (Lippson 1973).

The Chesapeake Bay is a highly branched, vast water body, with 19 principal rivers and 400 lesser creeks and streams functioning as its tributaries. The western shore rivers are generally larger than those on the eastern shore, but the eastern shore rivers are important for waterfowl as they are characterized by large expanses of marshlands that support great numbers of migratory waterfowl during autumn and winter (Lippson and Lippson 1984). The Bay is a comparatively shallow water body, generally low-lying and marshy in many areas, with the depth varying from a few spots $40-52 \mathrm{~m}$ deep to the tidal marshes exposed to low tide and located up the estuary. The tidal range is greatest $(0.76$ $\mathrm{m}$ ) at the mouth of the Bay and is about $0.61 \mathrm{~m}$ at the head of the Bay, with much of Maryland having a tidal range of $0.3-0.6 \mathrm{~m}$. The Bay currents are usually moderate and average well below $0.9 \mathrm{~km} / \mathrm{hr}$ (Lippson 1973). 
Sediments are continually added to the Bay from washing of soil into the tributaries. Homogeneous and gray/ black mud forms the floor of the main channel of Chesapeake Bay. Channel mud is composed mainly of silt-size particles with varying clay content. The majority of the Bay has clay-silt sediments. Fine-grained to mediumgrained sand is restricted to the edges/shores. The Bay in Maryland rarely has salinity greater than 20 parts per thousands (ppt; Lippson 1973). Salinity varies spatially and seasonally. Salinity increases as one goes from north to south. The salinity increases gradually downstream with $15 \mathrm{ppt}$ midway down the Bay. Salinity also varies from the surface to the bottom. Seasonal variation in salinity indicates that maximum salinity occurs in autumn and minimum salinity occurs in spring (Lippson 1973, Lippson and Lippson 1984).

More than 2,000 plants and animals have been identified from the Chesapeake Bay region, many of which are rare and/or localized (Lippson 1973). However, the overall health and diversity of the Bay has experienced a serious decline because of increased urban and industrial pollution (Hurley 1990).

As per the aerial survey carried out by the Maryland DNR in 2002, the population of Mute Swans (including molting flocks and breeding pairs) was highest (total 3,286 birds) along the eastern shore of the Chesapeake Bay. Unlike the eastern shore, the western shore had supported negligible numbers of Mute Swans. Therefore, the sites along the eastern shore of the Chesapeake Bay constitute the Study Area. The portions of the eastern shore of the Bay located in Dorchester County (1,638 swans), and Talbot County (1,023 swans) had supported a high number of Mute Swans at the time of aerial surveys in 2002 (Table 1, Fig. 2). Therefore, they form Study Area 1 and Study Area 2, and around 15 to 20 sites with breeding pairs and molting flocks of Mute Swans and SAV 
beds will be selected as study sites in these study areas after verification through reconnaissance in 2003 (18 sites were ultimately chosen and used as study sites).

\section{STUDY ORGANIZATION}

The research findings presented here are divided into 5 chapters. In Chapter 2, I present analyses and results regarding intensity of feeding activity of Mute Swans using time-activity budgets and suggest management implications. In chapter 3, I present analyses, results, and management implications regarding the impact of Mute Swan herbivory on percent cover, shoot density, and canopy height of SAV. In Chapter 4, I have conducted predictive modeling for SAV decline due to Mute Swans in the Chesapeake Bay. Chapter 5 is a summary of management implications and a list of additional research needs concerning Mute Swans in the Chesapeake Bay. 


\section{LITERATURE CITED}

Adams, S. 1976. The ecology of eelgrass, Zostera marina (L). Journal of Experimental Marine Biology and Ecology 22:269-291.

Allin, C. C. 1981. Mute Swans in the Atlantic Flyway. Proceedings of the International Waterfowl Symposium 4:149-154.

Atlantic Flyway Council 2003. Atlantic Flyway Mute Swan Management Plan 20032013. Atlantic Flyway Council, Laurel, MD, USA.

Bellrose, F. C. 1980. Ducks, geese and swans of North America. Stackpole Books, Harrisburg, Pennsylvania, USA.

Birkhead, M. E., and C. M. Perrins. 1986. The Mute Swan. Croom Helm, London, UK.

Blankenship, K. 2003. A sunnier future-goal would more than double Chesapeake's grass beds by 2010. Bay Journal 13:1.

Bortolus, A., O. Iribarne, and M. Marinez. 1998. Relationship between waterfowl and the sea grass Ruppia maritima in southwestern Atlantic coastal lagoon. Estuaries 221:710-717.

Chairman, K. 1977. The grazing of Zostera by waterfowl in Britain. Aquaculture $12: 229-233$.

Chasko, G. 1986. The impact of Mute Swans on waterfowl and waterfowl habitat. Wildlife Investigation: Waterfowl Research and Surveys, W-49-R-10, Final Report, Hartford, Connecticut, USA.

Ciaranca, M. A., C. C. Allin, and G. S. Jones. 1997. Mute Swan (Cygnus olor). Pages 1-26 in A. Poole and F. Gill (Eds). The Birds of North America, No. 273. The Academy of Natural Sciences, Philadelphia, Pennsylvania, and The American Ornithologists' Union, Washington, D.C., USA. 
Delach, A., R. Blaustein, and C. Muffett. 2001. Assessment and management of alien species that threaten ecosystems, habitats and species. Abstracts of poster presented at the sixth meeting of the Subsidiary Body on Scientific, Technical and Technological Advice Montreal, Canada (Unpublished).

Engel, S. 1990. Ecosystem responses to growth and control of submerged macrophytes. A literature review. Wisconsin Department of Natural Resources. Technical Bulletin 170. Madison, Wisconsin, USA.

Fenwick, G. H. 1983. Feeding behavior of waterfowl in relation to changing food resources in Chesapeake Bay. Dissertation, Johns Hopkins University, Baltimore, Maryland, USA.

Gillham, M. E. 1956. Feeding habits and seasonal movements of Mute Swan on two Devon estuaries. Bird Study 3:205-212.

Hindman, L. J. 1982. Feral Mute Swan population status and problems in the Atlantic Flyway with special reference to Maryland's population. Trumpeter Swan Society Conference 8:4-7.

Hindman, L. J. and V. D. Stotts. 1989. Chesapeake Bay and North Carolina Sounds. Pages 27-55 in L. M. Smith, R. L. Pederson, and R. M. Kaminski (Eds.). Habitat Management for migrating and wintering waterfowl in North America. Texas Tech University Press, Lubbock, Texas, USA.

Hindman, L. J. 2002. Invasive species in the Chesapeake watershed-Mute Swan (Cygnus olor). $<$ http://www.mdsg.umd.edu/exotics/workshops/mute_swan.html $>$.

Hindman, L. J. 2003. Mute Swans- Beautiful and Controversial Birds. $<$ http:// www.dnr.state.md.us/wildlife/muteswans.html> 
Hindman, L. J. 2003. Mute Swan impact on Chesapeake Bay grass. Microwave Telemetry Inc., Columbia, Maryland, USA. $<$ http://www.microwavetelemetry.com/newsletter_pdf/spring_03page8.pdf $>$

Hindman, L. J., and W. F. Harvey. 2004. Status and Management of Mute Swans in Maryland. Pages 11-17 in M.C. Perry (Ed.). Mute Swans and their Chesapeake Bay Habitats: Proceedings of a Symposium: U. S. Geological Survey, Biological Resources Discipline Information and Technology Report USGS/BRD/ITR2004-0005.

Hindman, L., B. Harvey, and D. Webster. 2005. Migratory Game Birds 2004-2005. Annual Report, Maryland DNR (Wildlife and Heritage Service), Annapolis, Maryland, USA. <http://www.dnr.state.md.us/wildlife/gpar/gpmgb.asp>

Hurley, L. M. 1990. Field guide to the submerged aquatic vegetation of Chesapeake Bay, U. S. Fish and Wildlife Service, Washington, D.C., USA.

Hurley, L. M. 1991. Submerged aquatic vegetation. Pages 12-19 in S.L. Funderburk, S. J. Jordan, J. A. Mihursky, and D. Riley (Eds.). Habitat requirements for Chesapeake bay- living resources. Maryland Department of Natural Resources, Annapolis, Maryland, USA.

Jennings, A. R., E. J. L. Soulsby, and C. B. Wainwright. 1961. An outbreak of disease in Mute Swans at an Essex reservoir. Bird Study 2:19-24.

Krull, J. N. 1970. Aquatic plant-macro invertebrate association and waterfowl. Journal of Wildlife Management 34:707-718.

Lippson, A. J. 1973. The Chesapeake Bay in Maryland: an atlas of natural resources. Johns Hopkins University Press, Baltimore, Maryland, USA. 
Lippson, A. J., and R. L. Lippson. 1984. Life in the Chesapeake Bay. Johns Hopkins University Press, Baltimore, Maryland, USA.

Markarian, M., and J. R. Lovvorn. 2004. Swan Song? Giving a voice to Mute Swans in the Chesapeake Bay. University of Baltimore School of Law, Baltimore. $<$ http://www.animallaw.info/articles/arus11ubaltjenvtl1115.htm>

Martin, A. C., and F. M. Uhler. 1951. Food of Game Ducks in the United States and Canada. Research Report 30 (USDA Tech. Bull. 634-1939), U. S. Fish and Wildlife Service, U. S. Department of the Interior, Washington, D. C., USA.

Maryland Department of Natural Resources. 2002. Mute Swan population survey shows decline, Unpublished report.

Mathiasson, S. 1973. A molting population of non-breeding Mute Swans with special reference to flight-feather molt, feeding ecology and habitat selection. Wildfowl 24:43-53.

Meyers, E., R. Fischman, and A. Marsh. 1995. Maryland Chesapeake Bay critical areas program: wetland protection and future growth. Pages 189-201 in D. R. Porter and D. A. Salvesen (Eds.). Collaborative planning for wetlands and wildlifeissues and examples. Island Press, Washington D. C., USA.

Munro, R. E., and M. C. Perry. 1982. Distribution and abundance of waterfowl and submerged aquatic vegetation in Chesapeake Bay. U. S. Environment Protection Agency, EPA 60013-82-092 NTIS PB82-266156, Washington, D. C.

Neirheus, P. H., and E. T. Van Ireland. 1978. Consumption of eelgrass, Zostera marina by birds and inveretebrates during the growing season in Lake Grevelington, Netherlands. Journal of Sea Research 12:180-194.

New York Department of Environmental Conservation. 1993. Policy on management of 
Mute Swan in New York. Albany, New York, USA.

Orth, R. J., and K.L. Heck, Jr. 1980. Structural components of eelgrass Zostera marina meadows in the lower Chesapeake Bay. Estuaries 3:278-288.

Owen, M., and C. J. Cadbury. 1975. The ecology and mortality of Mute Swans at the Ouses Washes, England. Wildfowl 25:31-42.

Perry, M. C. (Ed.). 2004. Mute Swans and their Chesapeake Bay habitats: Proceedings of a Symposium: U. S. Geological Survey, Biological Resources Discipline Information and Technology Report USGS/BRD/ITR-2004-0005.

Perry, M. C., P. C. Osenton, and E. J. R. Lohnes. 2004. Food habits of Mute Swans in Chesapeake Bay. Pages 31-36 in M. C. Perry, editor. Mute Swans and their Chesapeake Bay Habitats: Proceedings of a Symposium: U. S. Geological Survey, Biological Resources Discipline Information and Technology Report USGS/BRD/ITR- 2004-0005.

Petrie, S.A., and C. M. Francis. 2003. Rapid increase in the lower Great Lakes population of feral Mute Swans: a review and a recommendation. Wildlife Society Bulletin 31:407-416.

Reese, J. G. 1975. Productivity and management of feral Mute Swans in Chesapeake Bay. Journal of Wildlife Management 39:280-286.

Reese, J. G. 1980. Demography of European Mute Swans in Chesapeake Bay. Auk 97:449-464.

Scott, D. K., and M. E. Birkhead. 1983. Resources and reproductive performance in mute swans (Cygnus olor). Journal of Zoology 4:539-547.

Sondergaard, M., L. Bruun, T. Lauridsen, E. Jeppesen, and T. Vindbaek Madsen. 1996. 
The impact of grazing waterfowl on submerged macrophytes: in situ experiments in a shallow eutrophic lake. Aquatic Botany 53:73-84.

Sousa, C. M. 2005. Assessing the impact of Mute Swans in the Chesapeake Bay area of Maryland. Thesis, Cornell University, New York, USA.

Therres, G., and D. Brinker. 2004. Mute Swan interaction with other birds in Chesapeake Bay. Pages 43-46 in M. C. Perry (Ed.). Mute Swans and their Chesapeake Bay Habitats: Proceedings of a Symposium: U. S. Geological Survey, Biological Resources Discipline Information and Technology Report USGS/BRD/ITR- 2004-0005.

U.S. Fish and Wildlife Service. 2003. Submerged Aquatic Vegetation -Where have all the grasses gone? $<$ http://www.fws.gov/r5cbfo/CBSAV.HTM $>$

Voigts, D. K. 1976. Aquatic invertebrate abundance in relation to changing marsh vegetation. American Midland Naturalist 95:313-322.

Weller, M. W. 1969. Potential dangers of exotic waterfowl introductions. Wildfowl 20:55-58.

Whitman, W. R. 1976. Impoundments for waterfowl. Canadian Wildlife Service Occasional Paper 22. Ottawa, Cananda.

Wilmore, S. B. 1974. Swans of the world. Taplinger Publishing Company, New York, New York, USA. 
Table 1. County-wise population of Mute Swan in 2002 (Maryland DNR 2002).

\begin{tabular}{|c|c|c|c|c|c|c|}
\hline County & $\begin{array}{c}\text { Total } \\
\text { swans }\end{array}$ & $\begin{array}{r}\text { Pairs } \\
\text { with } \\
\text { cygnets }\end{array}$ & $\begin{array}{r}\text { Pairs } \\
\text { w/o } \\
\text { cygnets }\end{array}$ & $\begin{array}{l}\text { Single } \\
\text { swans }\end{array}$ & $\begin{array}{l}\text { Swans } \\
\text { in } \\
\text { groups }\end{array}$ & Cygnets \\
\hline Cecil & 10 & 1 & 3 & 1 & 0 & 1 \\
\hline Kent & 30 & 4 & 6 & 1 & 0 & 9 \\
\hline Queen Anne's & 511 & 25 & 19 & 11 & 339 & 73 \\
\hline Talbot & 1023 & 32 & 44 & 13 & 745 & 112 \\
\hline Dorchester & 1638 & 26 & 44 & 4 & 1393 & 101 \\
\hline Wicomico & 0 & 0 & 0 & 0 & 0 & 0 \\
\hline Somerset & 74 & 5 & 3 & 3 & 41 & 14 \\
\hline Eastern shore total & 3286 & 93 & 119 & 33 & 2518 & 310 \\
\hline Harford & 129 & 1 & 0 & 0 & 127 & 0 \\
\hline Baltimore & 38 & 5 & 5 & 0 & 9 & 9 \\
\hline Anne Arundel & 33 & 3 & 6 & 2 & 3 & 10 \\
\hline Patuxent River & 94 & 9 & 17 & 5 & 13 & 24 \\
\hline Western Bay shore & 26 & 2 & 3 & 3 & 0 & 13 \\
\hline Potomac River & 18 & 3 & 1 & 2 & 0 & 8 \\
\hline Western shore total & 338 & 23 & 32 & 12 & 152 & 216 \\
\hline Grand Total & 3624 & 116 & 151 & 45 & 2670 & 374 \\
\hline
\end{tabular}




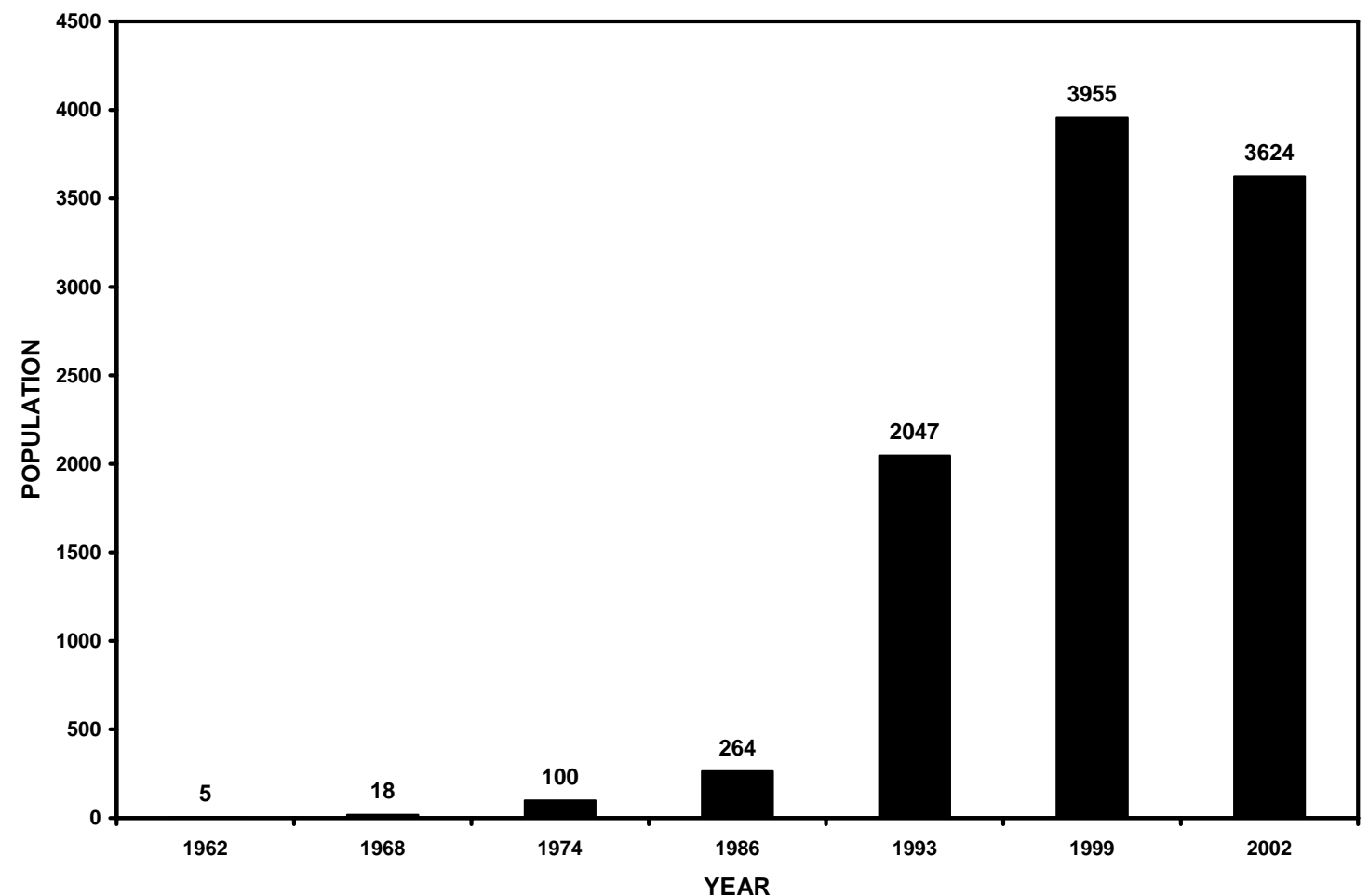

Figure 1. Number of Mute Swans in Maryland, 1962-2002 (Maryland DNR 2002). 


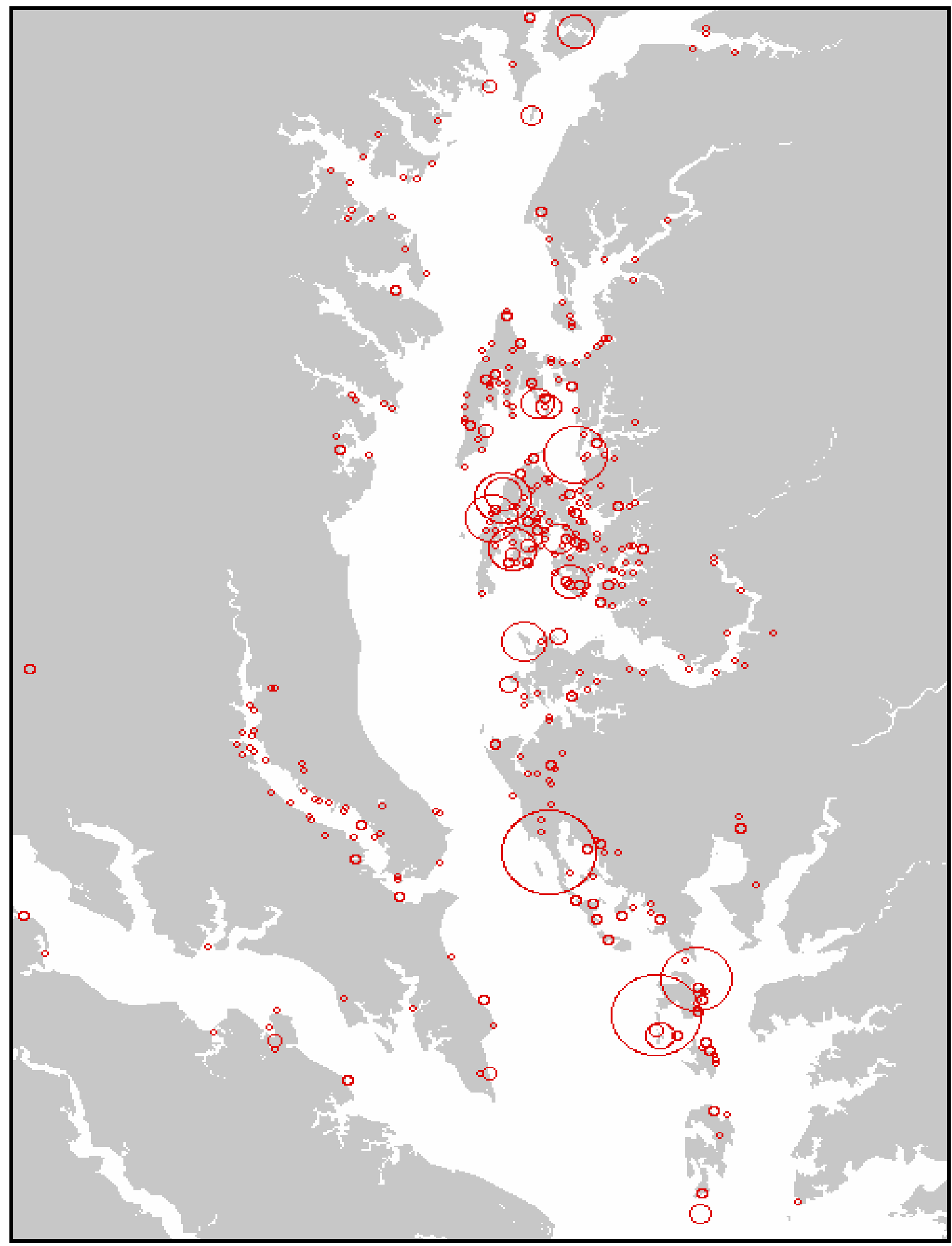

Figure 2. The distribution of Mute Swans in August-September 2002 (The largest circle represents 472 swans) (Source: Maryland DNR). 


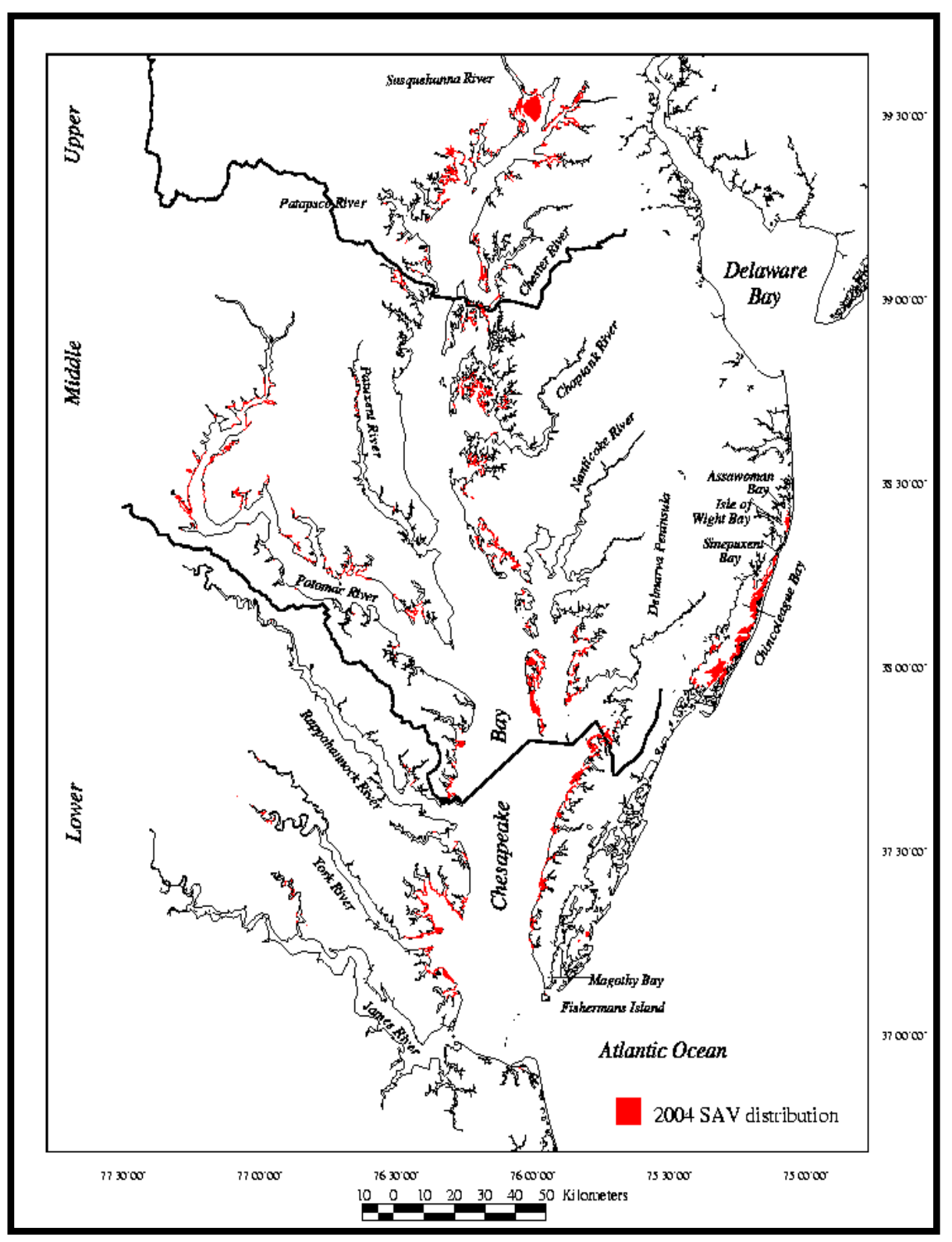

Figure 3. Location of Submerged Aquatic Vegetation (SAV) beds in the Chesapeake Bay in 2004, Virginia Institute of Marine Sciences (2004). 


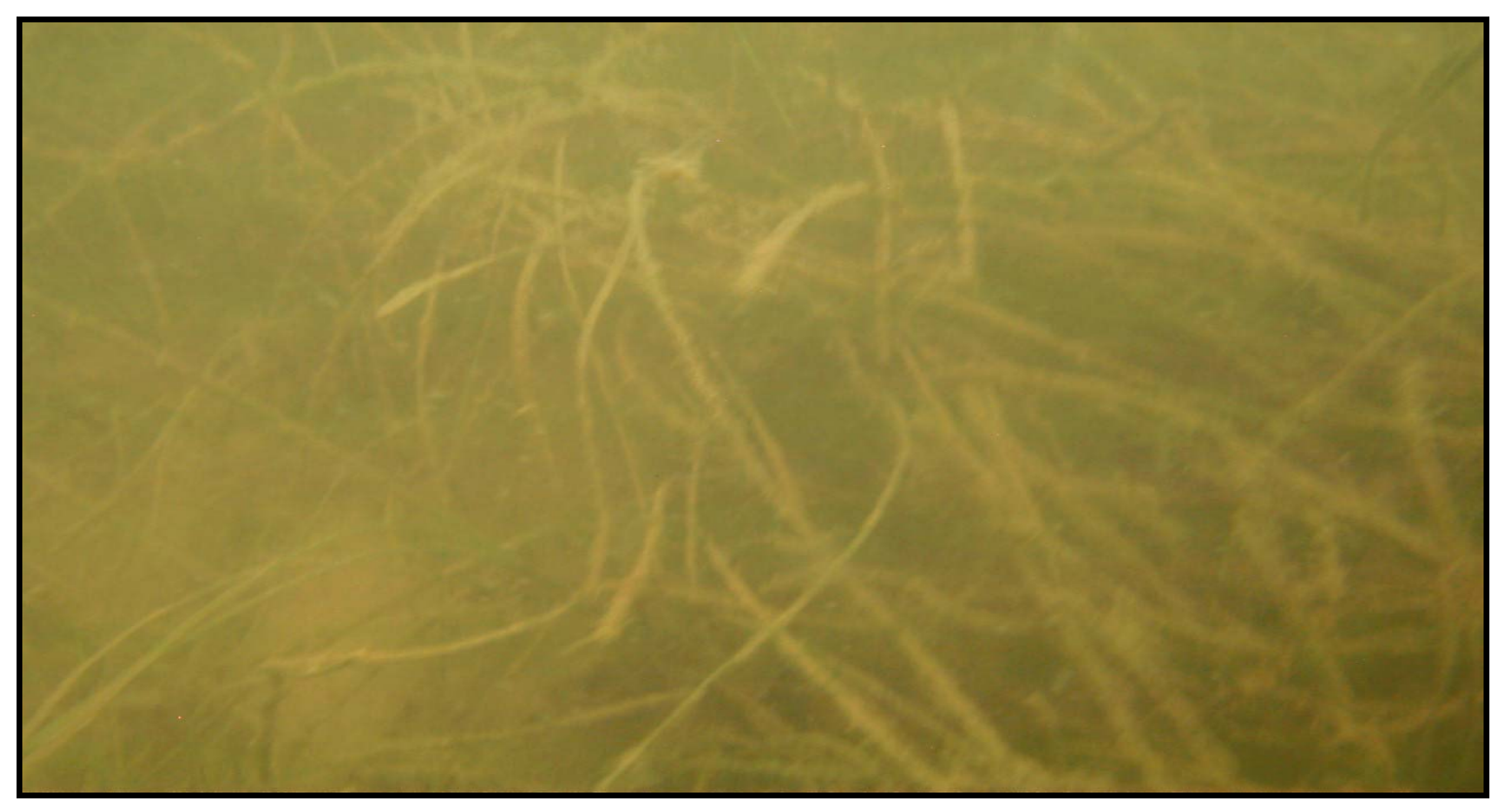

Figure 4. Submerged Aquatic Vegetation (SAV) in the Chesapeake Bay, Maryland.

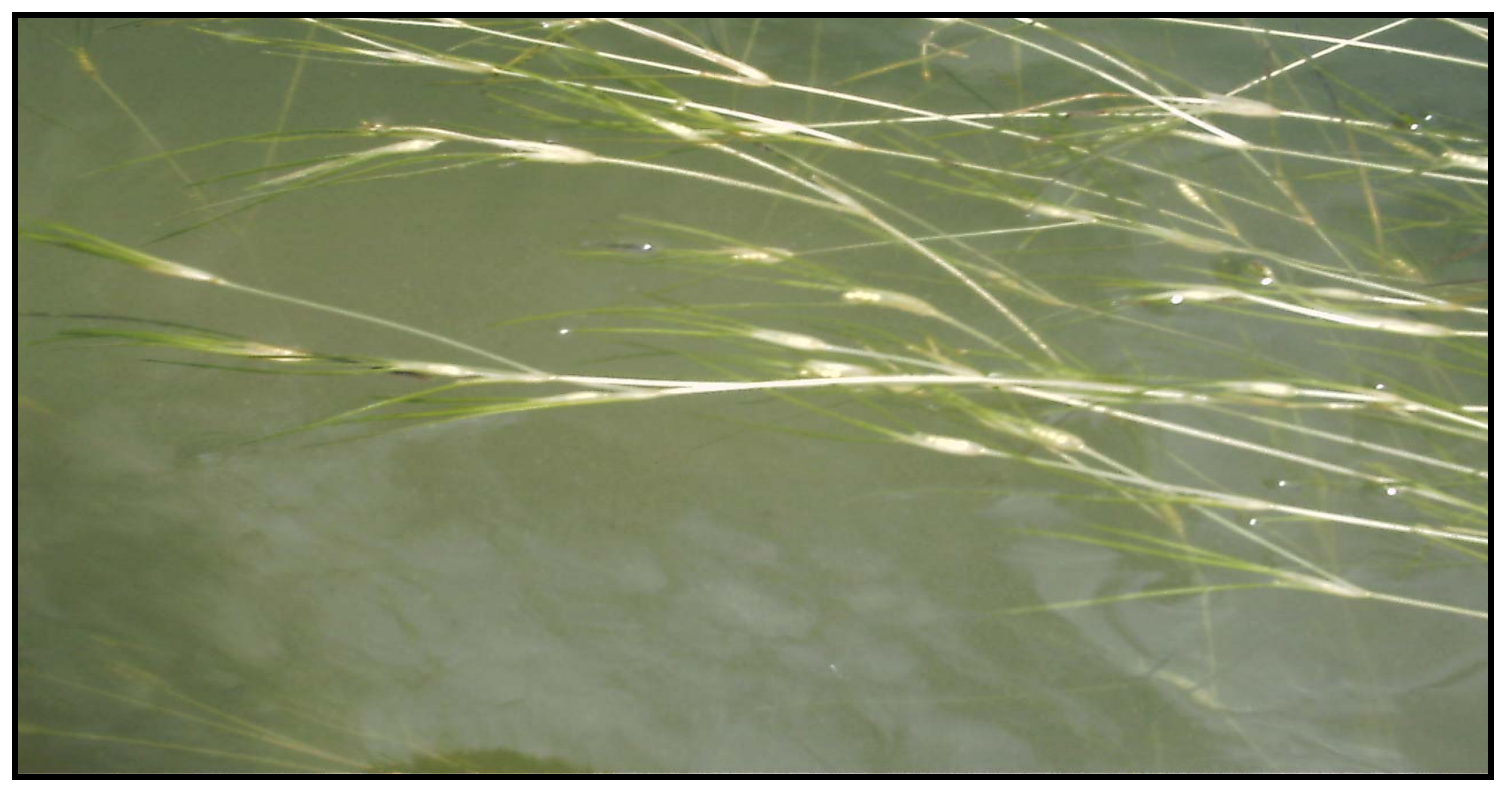

Figure 5. Widgeon grass (Ruppia maritima); the most abundant submerged aquatic plant species in the study area. 


\title{
CHAPTER II
}

2 April 2006

James T. Anderson

West Virginia University

Division of Forestry

PO Box 6125

Morgantown, WV 26506-6125

Phone: (304) 293-2941 x 2445

Fax: (304) 293-2441

E-mail: jander25@wvu.edu

RH: Mute Swan Activity Budgets

\section{ASSESSING FEEDING ACTIVITY OF MUTE SWANS IN CHESAPEAKE BAY, MARYLAND USING TIME-ACTIVITY BUDGETS}

\author{
KETAN S. TATU ${ }^{1}$, JAMES T. ANDERSON ${ }^{1}$, LARRY J. HINDMAN ${ }^{2}$ \\ AND GEORGE SEIDEL ${ }^{3}$
}

\footnotetext{
${ }^{1}$ Division of Forestry and Natural Resources, West Virginia University, P.O. Box 6125, Morgantown, WV 26506, USA Internet: jander25@wvu.edu

${ }^{2}$ Maryland Department of Natural Resources, 828BAirpax Road, Wildlife and Heritage Service, Cambridge, MD 21613, USA

${ }^{3}$ Department of Statistics, West Virginia University, P.O. Box 6330, Morgantown, WV 26506, USA
} 
Abstract.-We determined time-activity budgets of Mute Swans (Cygnus olor) at Chesapeake Bay, Maryland, USA with the principal aim of determining intensity of their feeding activity. Although Mute Swan herbivory is believed to contribute to declines in Submerged Aquatic Vegetation (SAV) in the Bay, there is a lack of comprehensive quantitative data indicating the magnitude of feeding activity by Mute Swans. We collected time-activity budgets from May through August $2003(\mathrm{~N}=50)$ and from March through August $2004(\mathrm{~N}=818)$ by spending about 10 hours each day. The proportion of time spent feeding (38.4\%) by Mute Swans was greater than time spent by them in nonforaging activities including swimming (21.8\%), resting (18.4\%), self-maintenance (18.6\%), agonistic activity (1.7\%), and disturbance-induced activities $(1.2 \%)(\mathrm{P}<0.001)$. Feeding activity of Mute Swans was not influenced by seasons (spring and summer). Mute Swans spent more time feeding than in non-foraging activities during the morning ( $\mathrm{P}=0.009)$ and midday $(\mathrm{P}=0.009)$. Mute Swans in flocks $(\geq 3$ individuals $)$ spent more time feeding than those in pairs $(\mathrm{P}=0.002)$. Moreover, Mute Swans in large flocks $(\mathrm{N}>$ 50 individuals) spent more time feeding than those in small flocks ( $\mathrm{N} \leq 10$ individuals) ( $\mathrm{P}$ $=0.004)$. Thus, swans in flocks pose a greater risk to the SAV in the Bay as compared to those in pairs and that swans in larger flocks likely pose a greater threat to SAV than those in the smaller flocks. This is because more time spent feeding by swans in flocks than those in pairs may lead to more SAV consumption as SAV is the mainstay of the diet of adult Mute Swans. Thus, the control of Mute Swan flocks (especially large ones) should be emphasized in the Bay.

Key words.- Chesapeake Bay, Cygnus olor, exotic species, feeding, focal sample, Mute Swans SAV, time-activity budget.

This chapter is written in the style of Waterbirds. 


\section{INTRODUCTION}

Mute Swans (Cygnus olor) are exotic in the United States and have inhabited the Atlantic Flyway since 1910 (Atlantic Flyway Council 2003). They have undergone phenomenal population growth in the Chesapeake Bay, especially in the portion of the Bay located in Maryland (Ciaranca et al. 1997, Maryland Department of Natural Resources [DNR] 2001, Hindman and Harvey 2004, Perry et al. 2004). Their numbers increased from 5 individuals in 1962 to about 4,000 individuals in 1999 in the Maryland portion of the Bay (Hindman and Harvey 2004). The problem of a dramatic population rise of Mute Swans is aggravated by their strong preference for Submerged Aquatic Vegetation (SAV) as a food resource which may lead to overgrazing (Ciaranca et al. 1997, Perry et al. 2004, Allin 1981, Maryland Department of Natural Resources 2001). Although there is anecdotal information to conclude that Mute Swans impact SAV in the Bay, the quantitative data on reduction of SAV by Mute Swans is limited (Hindman and Harvey 2004).

Determining the amount of time spent foraging is one of the basic requirements for assessing the impact of Mute Swans on SAV. However, comprehensive quantitative data evaluating feeding activity of Mute Swans in the Chesapeake Bay are lacking. Such data can be obtained by collecting time-and-activity budgets, because the budgets would facilitate determination of the proportion of feeding time with respect to total time spent in all the activities (Rave and Baldassarre 1989, Baldassarre and Bolen 1994). Moreover, time-and-activity budgets also can be used to determine consistency and predominance of feeding activity through different seasons and different time blocks in a day. Despite its usefulness, there is relatively little information published on activity patterns of Mute Swans (Holm 2002) and those in the Chesapeake Bay are no exception. Hitherto, time- 
and-activity budgeting has not been carried out for Mute Swans inhabiting the Chesapeake Bay. Data on time budgets for Mute Swans are, in fact, unavailable for the entire United States, except for Connecticut during the winter (Chasko 1986, Ciaranca et al. 1997).

We predicted that foraging would be the predominant activity of Mute Swans at the Chesapeake Bay. We hypothesized that the proportion of time spent foraging by Mute Swans in pairs would be less than the proportion of time spent foraging by swans in flocks. This is because an individual in a pair would have a well-established territory guarded from conspecifics other than its mate, and therefore sufficient food would be easier to obtain resulting in less time required for foraging (Maxon and Pace 1992). An individual in a flock may have to compete for food and contend with decreased food availability due to disturbance and interruption by other flock members (Goss-Custard 1970, 1976, 1977; Fleischer 1983), compelling it to spend more time in obtaining food in an opportunistic manner. We also anticipated that Mute Swans in bigger flocks would spend more time foraging than those in smaller flocks. We hypothesized that in a bigger flock, there would be greater intraspecific competition for obtaining food (SAV), which would stimulate each swan in a flock to spend more time obtaining SAV.

The objectives of our study were to determine consistency of feeding activity during different time periods of a day and seasons and to determine the difference in feeding intensity between breeding and non-breeding swans and among flock sizes. A secondary objective was to determine the type (i.e., intraspecific/interspecific) and intensity of aggression. 


\section{STUDY AREA}

We conducted this study on the eastern shore of Chesapeake Bay, Maryland, USA (Fig. 1). Chesapeake Bay is a $288 \mathrm{~km}$ long and 8-48 km wide shallow estuary, that lies in a north-south direction, roughly parallel to the Atlantic seacoast. The majority of the Bay is clay-silt sediments, but near the shore of the Bay fine-grained to medium-grained sand occurs. Salinity varies spatially and seasonally, but rarely exceeds 20 parts per thousand (ppt) (Lippson 1973, Lippson and Lippson 1984). The study area was primarily mesohaline (5-18 ppt) (Lippson 1973, Hurley 1990, Maryland DNR 2005). The population of Mute Swans (including non-breeding flocks and breeding pairs) was highest (total 3,286 individuals) along the eastern shore of the Chesapeake Bay. Moreover, the portions of the eastern shore located in Dorchester (1,638 swans) and Talbot (1,023 swans) Counties supported high number of Mute Swans at the time of aerial surveys in 2002 (Hindman and Harvey 2004). During 2003 and early spring of 2004, activity patterns were studied wherever pairs or flocks of Mute Swans were encountered in the study area. However, during late spring and summer (May to August 2004), the study was restricted to 18 sites (8 in Talbot County and 10 in Dorchester County) located between $38^{\circ} 35^{\prime} \mathrm{N}$ and $38^{\circ} 50^{\prime} \mathrm{N}$ latitudes and $76^{\circ} 05^{\prime} \mathrm{E}$ and $76^{\circ} 20^{\prime}$ longitudes.

\section{METHODS}

\section{Data Collection}

We used focal sampling techniques (Altman 1974, Rave and Baldassarre 1989) to record behaviors of Mute Swans from May through August 2003, and March through August 2004. We stratified observations by time of day: morning (0630 to 1130), mid- 
day (1200 to 1600$)$, and evening (1730 to 1930) and season: early spring (15 March to 30 April), late spring (1 May to 20 June), and summer (21 June to 15 August). We observed randomly selected Mute Swans using 8 x 40 binoculars from the shore and stayed far enough away (i.e., $>200 \mathrm{~m}$ ) to avoid influencing their behavior. We observed each selected swan for 10 minutes and recorded its activities at 10-second intervals using a micro-cassette recorder. Usually, an observer carried two micro-cassette recorders; one for playing back pre-recorded 10-second intervals (for total 10 minutes) and another one for recording instantaneous behavior at 10 -second intervals in response to the time interval played back. We recorded 16 types of activities, that were pooled into 6 general categories (i.e., feeding, self-maintenance, resting, swimming, agonistic, and disturbance-related) (Table 1).

We classified Mute Swans social status as being in pairs or flocks. We defined a pair as two swans defending a territory for breeding and/or feeding and having the potential to breed. Paired swans often occurred with their young at 3 sites in Talbot County and 1 site in Dorchester County during summer. We defined a flock as a congregation of unpaired swans that did not indulge in territorial defense while carrying out foraging and non-foraging activities together. Flocks included non-breeding individuals (e.g., unmated birds, molting individuals, and young from previous years). We further characterized flock size as small $(3 \leq \mathrm{N} \leq 10)$, medium $(11 \leq \mathrm{N} \leq 50)$, or large $(51 \leq \mathrm{N} \leq 150)$

\section{Data Analyses}

We considered each 10-minute swan observation as an independent sampling unit. We calculated time budgets as the percentage of time spent performing specific 
activities. They were calculated using least square means of activity proportions.

Residual examination indicated that, although the data were expressed as percentages, a square root transformation was effective in satisfying assumptions of normality and homogeneity of variances. We used Analysis of Variance (ANOVA) procedures using Generalized Linear Models (GLM) in SAS version 8 (SAS Institute 2001) to assess the effects of season, time of day, and social status (i.e., pair, small flock, large flock) on time-activity budgets of Mute Swans. An ANOVA model including season, time of day, social status, and behavior category was used. We used contrast statements to compare means for pairs to means from flocks; means among flock size categories, and means among activities for each social status class.

We also used ANOVA procedures to detect whether or not Mute Swans used all foraging strategies equally (i.e., submersing head and neck in water, submersing head only, feeding from the surface without submersing head or neck, and up-ending). Differences among means were identified using $t$ - tests to perform pair-wise multiple comparisons among different activity types.

Significance for all statistical inferences was $\mathrm{P} \leq 0.05$. Data from 2004 were used in analyses. Data from 2003 are presented for comparative purpose, but due to the much smaller sample size was not used to compare years.

\section{RESULTS}

We calculated time-activity budgets for 50 Mute Swans in 2003 and 818 individuals in 2004. A total of 123 pairs and 189 flocks was observed. The average size of large flocks was 75 individuals $(\mathrm{SE}=25)$, whereas that of small flocks was 7 individuals $(\mathrm{SE}=3)$. We made 360 10-minute observations during morning, 293 
observations during mid-day and 165 observations during evening. A total of 390 observations was made during spring (early spring: $30 \%$, late spring: $70 \%$ ), whereas a total of 428 observations was made during summer.

Overall Time Budget and Predominance of Feeding Activity

Mute Swans spent the most time foraging though they also spent a considerable amount of time in swimming, self-maintenance, and resting activities (Table 2, Fig. 2). Mute Swan foraging was not influenced by season $\left(\mathrm{F}_{2,57}=1.10 ; \mathrm{P}=0.341\right)$. Of the three time-blocks of swan observations, Mute Swans spent more time feeding than in nonforaging activities during morning $\left(\mathrm{t}_{17}=2.94, \mathrm{P}<0.009\right)$ and mid-day $\left(\mathrm{t}_{24}=2.85, \mathrm{P}<\right.$ $0.009)$ time blocks. There was no season by time block interaction for foraging $\left(\mathrm{F}_{4,57}=\right.$ $0.33 ; \mathrm{P}=0.857$ ). However, the social status (i.e., pair, small/large flock) of Mute Swans influenced the amount of time spent foraging $\left(\mathrm{F}_{3,691}=17.11, \mathrm{P}<0.001\right)$. Mute Swans in flocks spent more time feeding than those in pairs $\left(\mathrm{F}_{1,691}=9.59, \mathrm{P}<0.002\right)$ (Table 2). Moreover, Mute Swans in large flocks spent more time feeding than those in small flocks $\left(\mathrm{F}_{1,691}=8.57, \mathrm{P}<0.004\right)($ Table 2$)$.

\section{Foraging Strategies}

Mute Swans did not use all foraging strategies equally $\left(\mathrm{F}_{3,3032}=137.41, \mathrm{P}<\right.$ 0.001) (Fig. 3). They spent most of their feeding time using the dipping with head-andneck submersed strategy, followed by dipping with head-only submersed. The strategy of feeding from the water surface was used to a lesser extent and upending was the least used strategy (P<0.001) (Fig. 3). 
Agonistic Behavior While Feeding

Feeding activity of Mute Swans, especially of those in pairs, was found to be occasionally interrupted due to their territorial behavior. Of the total events of agonistic activity $(\mathrm{N}=854)$ recorded during spring and summer seasons of $2004,99.5 \%$ were intraspecific, whereas only $0.5 \%$ were interspecific. Interspecific encounters were recorded for Great Blue Heron (Ardea herodias) $(\mathrm{N}=1)$ and humans $(\mathrm{N}=3)$.

\section{DISCUSSION}

Overall Time Budget and Predominance of Foraging Activity

We calculated a comprehensive time budget for exotic Mute Swans on the Chesapeake Bay, Maryland based on 136 hours of observations and determined that foraging was the primary diurnal activity (2003: $43 \%$ of the time, $2004: 38 \%$ of the time). Such work has not previously been carried out for Mute Swans in the Bay. A time budget for Mute Swans was calculated in Connecticut during the winter, based on 63 hours of observations of 200-300 Mute Swans (Chasko 1986). Although data of this study are from a different place and season in the United States, it also revealed that feeding was the most common activity ( $44 \%$ of the diurnal time). Thus, proportion of time spent feeding by Mute Swans at two different places and during two different seasons in the United States was considerably similar. The proportion of feeding time of Mute Swans in the Chesapeake Bay was similar to those wintering at a tidally influenced man-made brackish water lagoon Harboør Fjord in Denmark. Thus, at Harboør Fjord, swans spent $41 \%$ (i.e., $0.41 \pm 0.22$ ) of diurnal time feeding between September 1999 and January 2000 (Holm 2002). 
However, Mute Swans in the Chesapeake Bay spent more time feeding than they do in Scotland, because a non-breeding population (e.g. flocks) of Mute Swans spent only $32 \%$ of their time feeding ( $25 \%$ in water, $7 \%$ grazing on land) (Black and Rees 1984 ). The time budget for the Chesapeake Bay population of Mute Swans represents feeding in water only. Thus, it is evident that the Chesapeake Bay population fed 13-19\% longer in water compared to Scotland population. Therefore, it is likely that the Mute Swan population in the United States is more dependent on water for feeding and in turn, more detrimental to the aquatic vegetation. In the study in Scotland, Mute Swans may have a more assured food supply from land use/cover in urban and rural areas, probably making them less dependent on (and therefore less detrimental to) aquatic vegetation.

In England, unlike in the United States, urban flocks of Mute Swans represent a sizeable proportion of the national population (Owen and Kear 1972). These urban flocks have successfully survived and proliferated by consuming bread and other foods provided by the public (Owen and Kear 1972, Birkhead and Perrins 1986). In parts of Scotland, it is normal to find flocks of wintering swans feeding on the refuse from fishing fleets, and on wastes from sewers (Owen and Kear 1972). Large flocks, sometimes numbering several hundred birds, are attracted by the waste grain from mills, maltings, and distilleries (Owen and Kear 1972). Such heavy dependence on agricultural food sources has not been recorded in North America with some exceptions like artificial feeding in British Columbia, Canada and Traverse City, Michigan, USA (Ciaranca et al. 1997). Moreover, the population of Mute Swans in England and Scotland can feed on agricultural crops in fields and can also wander in grasslands in winter and spring, when aquatic vegetation dies back (Birkhead and Perrins 1986, Chisholm and Spray 2002). Mute Swans in the United States do not typically feed on agricultural crops. At the 
Chesapeake Bay in particular, they forage almost exclusively on SAV (Perry et al. 2004). In Maryland, small numbers of pairs have been observed feeding on turf grass and winter wheat (Larry Hindman, Maryland DNR, personal communication).

Comparison of other activities in the Connecticut study and those in our study showed that the proportion of self-maintenance activities (16\% vs. $18 \%$ ), that of resting activity ( $12 \%$ vs. $18 \%)$, and interspecies interaction $(<1 \%$ in both studies) were similar. However, there was a substantial difference in proportion of swimming time (12\% vs. $21 \%$ ), which may be due to the difference in season covered by the two studies. The study in Connecticut was conducted in winter, when swan movements are likely to be restricted by ice and breeding territory formation/guarding (Ciaranca et al. 1997). As our study was conducted during the spring and summer seasons, the proportion of time spent swimming for food acquisition, locomotion, and disturbance may have been greater due to a lack of ice. In fact, swimming was the second-most common (i.e., 21\%) activity of Mute Swans in the Bay. Mute Swans can make substantial movements in the Bay. Monitoring of 6 swans during 2002 using radio telemetry showed that they move up to 3 $\mathrm{km}$ in an hour (Christine Sousa, Cornell University, personal communication). It also was found that radio-collared swans in flocks traveled up to $32 \mathrm{~km}$ from their banding location, despite the tendency of radio-collared swans to remain near the banding sites due to the possible influence of transmitters or backpack harness (Sousa 2005).

\section{Influence of Time Variations and Social Status}

Variation in time spent by Mute Swans in feeding in the Bay from early spring through summer and across different diurnal time blocks was insignificant. Feeding was consistently a major activity of Mute Swans throughout the day during spring and 
summer. Lengthy diurnal feeding periods are characteristic of waterfowl that do not feed on the seeds of agricultural plants, but rather graze or prefer leafy aquatic vegetation (Baldassarre and Bolen 1994) owing to the relatively low digestible energy density of leafy vegetation (Sedinger 1997). Our study shows that Mute Swans are no exception to this observation. This is because leaves of SAV predominates Mute Swans' food at several localities in the Chesapeake Bay (Perry et al. 2004). In England too, proportion of leaves of aquatic plants (i.e., 57\%) was larger than the proportion of roots and tubers (i.e., 43\%) in diet of Mute Swans (Owen and Cadbury 1975). Similar responses have been recorded for other waterfowl consuming leafy vegetation (Paulus 1984, Quinlan and Baldassarre 1987, Turnbull and Baldassarre 1987, McKnight 1998, LaMontagne et al. 2001).

Our study did not include nocturnal observations. In general, nocturnal use of wetlands by waterfowl can be substantial (Anderson and Smith 1999). However, the importance of nocturnal observation of Mute Swans in Chesapeake Bay cannot be decided clearly because the European population of Mute Swans is known to feed predominantly during the day (Keane and O' Halloran 1992) and Trumpeter Swans in Wyoming and Idaho, USA, mostly fed by day after the cygnets hatched (Henson and Cooper 1994). On the other hand, nocturnal feeding was as predominant as diurnal feeding in Trumpeter Swans (Cygnus buccinator) during the prelaying period in Wyoming and Idaho (Henson and Cooper 1994). We emphasize that inference from our results on Mute Swans in the Chesapeake Bay is restricted to the diurnal period of spring and summer only. 
Foraging Time of Pairs, Small Flocks, and Large Flocks

Paired Mute Swans spent less time foraging than those in flocks. The potential reason is that a pair, due to its dominance over unpaired birds in a flock, may defend better quality feeding area in the form of a well-established territory. Thus, its occupants would have a relatively assured source of food (SAV) and they would have a greater familiarity with sources of food in it (Anderson and Titman 1992). This in turn, would result in less time spent in search of food. Moreover, the better quality feeding habitat in the form of territories would be guarded by one or both individual(s) in a territorial pair from other unpaired conspecifics (Baldassarre and Bolen 1994). This may lead to a relatively shorter feeding time spent by the pair as one or both individual(s) in the pair may carry out relatively uninterrupted feeding activity. For example, paired males of Northern Shovelers (Anas clypeata) in Manitoba, Canada maintained isolation for their mates through territorial defense (Afton 1979). Consequently, foraging activity of females was rarely interrupted after territory establishment which facilitated efficient feeding (Afton 1979).

Unlike paired Mute Swans, unpaired individuals in flocks may not control good feeding grounds in the form of territories and in turn, forage in poorer quality habitats, wherein they may have no/less familiarity with the food resources. This may result in longer foraging time. In Alabama, unpaired Gadwalls foraged faster (i.e., traveled farther per unit time) than paired individuals, which indicated that they foraged in poorer quality microhabitats than did paired birds (McKnight 1998). Moreover, feeding activity of Mute Swans in flocks can be interrupted by conspecifics competing for the common food resource. Thus, they would spend a longer time foraging. During our study, Mute Swans in the Chesapeake Bay in large flocks spent more time feeding than those in small flocks. 
More time spent feeding by individuals in large flocks may be due to reduced foraging success with the increase in flock size (Petit and Bildstein 1987). It is likely that food depletion, fighting over food, and decreased food availability due to disturbance or interruption by other flock members would increase with the increase in flock size (GossCustard 1969, 1970, 1976; Horwood and Goss-Custard 1977; Fleischer 1983) leading to longer time spent in feeding activity by the individuals in large flocks.

\section{Feeding Strategies}

Our study indicated that Mute Swans employed dipping ('head-and-neck' and headonly') strategy in open tidal water up to $94 \%$ of the feeding time ( $70 \%$ of feeding time in head-and-neck dipping and $24 \%$ in head-only dipping). Thus head-and-neck dipping was the predominant foraging strategy of Mute Swans in the Chesapeake Bay. It also was the predominant strategy of the wintering Mute Swans between early October 1999 and late January 2000 in the man-made brackish water lagoon Harboør Fjord in Denmark (Holm 2002). Mute Swans in non-tidal waters in England used dipping up to $79 \%$ of the time and generally used it in water $20-45 \mathrm{~cm}$ deep (in the Thames River area), but also up to $79 \mathrm{~cm}$ deep (in Ouses Washes)(Owen and Cadbury 1975, Sears 1989). Mute Swans in Chesapeake Bay used upending only $2 \%$ compared to $21 \%$ of the time in Upper Thames, England (Sears 1989) and up to about 50\% of the time during January 2000 in the manmade brackish water lagoon at Harboør Fjord, Denmark (Holm 2002). The average depth of upending in the localities of the Bay covered during our study was $125 \mathrm{~cm}$, which was more than the depth of upending by Mute Swans recorded in England (i.e., 45$103 \mathrm{~cm})($ Owen and Cadbury 1975). It is likely that SAV occurred at greater depth in the Bay as compared to that in England resulting into greater upending depth in the Bay. 
Mute Swans also obtain food from the water surface (Ciaranca et al. 1997). In Chesapeake Bay they spent only $4 \%$ of their feeding time in obtaining food from the water surface. Usually, Mute Swans employ a surface feeding strategy for obtaining food from the water surface, in which they keep their bills horizontal along the surface of water to skim/sieve food items (Gelston and Wood 1982). But, they seldom employed surface feeding in its strictest sense in the Bay. Rather, they commonly used the strategy of dipping the beak only, with head/neck remaining above the water surface (and not parallel to and in touch with the water surface as in surface feeding). In the Thames River area in England, a surface feeding strategy was used $51-60 \%$ of the time (Sears 1989). One of the potential reasons for the lesser use of surface feeding strategy by Mute Swans in the Bay as compared to those in England is the possibility of more disturbed water surface in the tidal habitat of the Bay. It is likely that food collection from the disturbed water surface of a tidal water habitat would be more difficult as compared to food harnessing in non-tidal habitats in England. Another potential reason may be the difference between food available in Chesapeake Bay and that in England. In Chesapeake Bay, Maryland Mute Swans rely heavily on widgeon grass (Hindman 1982), that remains under the water surface except when in reproductive stage. On other hand, Mute Swans in non-tidal waters in England not only feed on submerged macrophytes like common waterweed (Elodea Canadensis) and water starwort (Callitriche sp.), but also feed on many species of emergent plants and filamentous green algae (Wilmore 1974, Owen and Cadburry 1975) that can occur at water surface. 
Agonistic Activities

Intraspecific agonistic activity was usually carried out through 'busking' display (i.e., a type of display comprising several wing and neck postures [Ciaranca et al. 1997]), which compelled a displaying swan to stop feeding for a few minutes in a single bout while attempting to drive away the intruding swan. We did not observe any physical contact between swans. Intraspecific agonistic activity was more common than interspecific agonistic activity and thus conspecific individuals were more responsible for causing interruption in feeding activity. Most aggressive interactions in waterfowl are intraspecific and occur while one or both of the participating parties are feeding (Baldassarre and Bolen 1994).

Interspecific agonistic activity was carried out only by paired Mute Swans. A feeding individual in a pair rushed aggressively towards a Great Blue Heron (Ardea herodias) when the heron waiting for its prey occurred in the proximity of the swan which was swimming slowly while feeding. The heron was compelled to fly away due to the aggressive behavior which took place twice during a single event. Loud hissing was directed towards humans when, people closely approached paired swans with and without young. We speculate that more agonistic behavior probably occurred during mating and nesting (Anderson and Titman 1992) which occurs between late February and early March (Ciaranca et al. 1997). Mute Swans on the Chesapeake Bay have been aggressive towards other native birds like Tundra Swans (Cygnus columbianus) (Hindman and Harvey 2004). They also have killed Canada Goose goslings and Mallard (Anas platyrhynchos) duckling in Maryland (Larry Hindman, Maryland DNR, personal communication). 


\section{Management Implications}

Our study has demonstrated that feeding is indeed dominant activity of Mute Swans at Chesapeake Bay, Maryland irrespective of seasonal and diurnal time periods. As SAV is known to be the main diet item of these exotic swans (Perry et al. 2004), high feeding intensity is indeed a matter of concern. Mute Swans in flocks spend more time feeding than those in breeding pairs and swans in larger flocks spend more time feeding than those in smaller flocks. Flocks, especially larger ones, are more detrimental to SAV in the Bay as compared to pairs (Cobb and Harlin 1980). Pair bonds may be formed in flocks (Birkhead and Perrins 1986) and thus flocks also are the origin of future population growth. Therefore, management efforts to protect and restore SAV should emphasize controlling Mute Swans, especially those in larger flocks, rather than concentrating solely on addling eggs. Oiling/addling eggs slows population growth and targets the life stage with the highest natural mortality. We recommend implementing the combination of egg addling and removal of adult Mute Swans to reduce impact of Mute Swans on SAV.

\section{ACKNOWLEDGEMENTS}

Funding for this work was provided by Federal Aid in Wildlife Restoration, grantW-61-R to Maryland DNR and Maryland Migratory Game Bird Stamp Funds. We thank Andrew Isner, Jon Chandler, Troy Osborne, Joseph Osbourne, Seth Lemley, Dave Helon, and Collin Balcombe of West Virginia University, and Brent Evans of Maryland DNR for field assistance and property owners for allowing access to the Bay. This is scientific article number XXXX of the West Virginia University Agricultural and Forestry Experiment Station. 


\section{LITERATURE CITED}

Afton, A. D. 1979. Time budget of breeding Northern Shovelers. Wilson Bulletin 91: 42-49.

Allin, C. C. 1981. Mute Swans in the Atlantic Flyway. Proceedings of the International Waterfowl Symposium 4: 49-154.

Altman, J. 1974. Observational study of behavior: sampling methods. Behavior 49: 227-267.

Anderson, J. T. and L. M. Smith. 1999. Carrying capacity and diel use of managed playa wetlands by nonbreeding waterbirds. Wildlife Society Bulletin 27: 281-291.

Anderson, M. G. and R. D. Titman. 1992. Spacing patterns. Pages 251-289 in B. D. J. Batt, A. D. Afton, M. G. Anderson, C. D. Ankney, D. H. Johnson, J. A. Kadlec and G. L. Krapu (Eds.). Ecology and management of breeding Waterfowl. University of Minnesota Press, Minneapolis, Minnesota.

Atlantic Flyway Council 2003. Atlantic Flyway Mute Swan Management Plan 20032013. Atlantic Flyway Council, Laurel, Maryland, USA.

Baldassarre, G. A. and E. G. Bolen. 1994. Waterfowl ecology and management. John Wiley \& Sons, New York, New York.

Birkhead, M. and C. Perrins. 1986. The Mute Swan. Croom-Helm, London.

Black, J. M. and E. C. Rees. 1984. The structure and behavior of the Whooper Swan population wintering at Caerlaverock, Dumfries, and Galloway, Scotland: an introductory study. Wildfowl 35: 21-36.

Chasko, G. 1986. The impact of Mute Swans on waterfowl and waterfowl habitat. Wildlife Investigation: Waterfowl Research and Surveys, CT. W-49-R-10, Final Report, Hartford. 
Chisholm, H. and C. Spray. 2002. Habitat usage and field choice by Mute and Whooper Swans in the Tweed Valley, Scotland. Pages 177-182 in E. C. Rees, S. L. Earnst, and J.Coulson (Eds.). Proceedings of the Fourth International Swan Symposium, 2001. Waterbirds 25, Special Publication 1.

Ciaranca, M. A., C. C. Allin and G. S. Jones. 1997. Mute Swan (Cygnus olor). Pages 126 in A. Poole and F. Gill (Eds.). The Birds of North America, No. 273. The Academy of Natural Sciences, Philadelphia, Pennsylvania.

Cobb, J. S. and M. M. Harlin. 1980. Mute Swan feeding and territoriality affects diversity and density of rooted aquatic vegetation. American Zoologist 20: 882.

Fleischer, R. C. 1983. Relationships between tidal oscillations and Ruddy Turnstone flocking, foraging, and vigilance behavior. Condor 85: 22-29.

Gelston, W. L. and R. D. Wood. 1982. The Mute Swan in Northern Michigan. Myers Printing Service. Grand Traverse Swans, Inc. Traverse City, Miami.

Goss-Custard, J. D. 1969. The winter feeding ecology of the Redshank Tringu totanus. Ibis 111: 338-356.

Goss-Custard, J. D. 1970. The responses of Redshank (Tringu totanus [L.]) to spatial variations in the density of their prey. Journal of Animal Ecology 39: 91-113.

Goss-Custard, J. D. 1976. Variation in the dispersion of Redshank Tringu totanus, on their winter feeding grounds. Ibis 118: 257-263.

Goss-Custard, J. D. 1977. Density-related behaviour and the possible effects of a loss of feeding grounds on wading birds (Charadrii). Journal of Applied Ecology 14: 721-739.

Henson, P. and J. A. Cooper. 1994. Nocturnal behavior of breeding Trumpeter Swans. The Auk 111: 1013-1018. 
Hindman, L. J. 1982. Feral Mute Swan population status and problems in the Atlantic Flyway with special reference to Maryland's population. Trumpeter Swan Society Conference 8: 4-7.

Hindman, L. J. and W. F. Harvey. 2004. Status and Management of Mute Swans in Maryland. Pages 11-17 in M.C. Perry (Ed.). Mute Swans and their Chesapeake Bay Habitats: Proceedings of a Symposium: U. S. Geological Survey, Biological Resources Discipline Information and Technology Report USGS/BRD/ITR2004-0005, Reston.

Holm, T. E. 2002. Habitat use and activity patterns of Mute Swans at a molting and wintering sites in Denmark. Pages 183-191 in E. C. Rees, S. L. Earnst, and J. Coulson (Eds.). Proceedings of the Fourth International Swan Symposium, 2001. Waterbirds 25, Special Publication 1.

Horwood, J. and J. D. Goss-Custard. 1977. Predation by the oystercatcher Huematopus ostrulegus (L.), in relation to the cockle, Cerustodermu edule (L.), fishery in the Burry Inlet, South Wales. Journal of Applied Ecology 14: 139-158.

Hurley, L. M. 1990. Field guide to the submerged aquatic vegetation of Chesapeake Bay. U. S. Fish and Wildlife Service, Annapolis, Maryland.

Keane, E. M. and J. O' Halloran. 1992. The behavior of a wintering flock of a wintering flock of Mute Swans Cygnus olor in southern Ireland. Wildfowl 43: 12-19.

LaMontagne, J. M., R. M. R. Barclay and L. J. Jackson. 2001. Trumpeter Swan behavior at spring-migration stopover areas in southern Alberta. Canadian Journal of Zoology 79: 2036-2042.

Lippson, A. J. 1973. The Chesapeake Bay in Maryland: an atlas of natural resources. 
Johns Hopkins University Press, Baltimore, Maryland.

Lippson, A. J. and R. L. Lippson. 1984. Life in the Chesapeake Bay. Johns Hopkins University Press, Baltimore, Maryland.

Maryland Department of Natural Resources. 2001. Mute Swans-population status, impacts on native wildlife and people, and management needs in Maryland. Mute Swan Task Force 2001. A summary of information prepared by the Maryland Department of Natural Resources, Annapolis, Maryland.

Maryland Department of Natural Resources. 2005. Recent water and habitat conditions in Maryland's Chesapeake Bay and Coastal Bays (online). available http://mddnr.chesapeakebay.net/eyesonthebay/index.cfm, January 1, 2005.

Maxon, S. J. and R. M. Pace. 1992. Diurnal time-activity budgets and habitat use of Ring-necked Duck ducklings in north central Minnesota. Wilson Bulletin 104: $472-484$.

McKnight, S. K. 1998. Effects of food abundance and environmental parameters on foraging behavior of Gadwalls and American Coots in winter. Canadian Journal of Zoology 76: 1993-1998.

Owen, M. and C. J. Cadbury. 1975. The ecology and mortality of Mute Swans at the Ouses Washes, England. Wildfowl 25: 31-42.

Owen, M. and J. Kear. 1972. Food and feeding habits. Pages 58-77 in P. Scott (Ed.). The Swans. Houghton Mifflin Co., Boston, Massachusetts.

Paulus, S. L. 1984. Activity budgets of non-breeding Gadwalls in Louisiana. Journal of Wildlife Management 46: 71-79.

Perry, M. C., P. C. Osenton and E. J. R. Lohnes. 2004. Food habits of Mute Swans in Chesapeake Bay. Pages 31-36 in M. C. Perry (Ed.). Mute Swans and their 
Chesapeake Bay Habitats: Proceedings of a Symposium: U. S. Geological Survey, Biological Resources Discipline Information and Technology Report USGS/BRD/ITR - 2004-0005, Reston.

Petit, D. and K. Bildstein. 1987. Effect of group size and location within the group on the foraging behavior of White Ibises. Condor 89: 602-609.

Quinlan, E. E. and G. A. Baldassarre. 1984. Activity budgets of nonbreeding Greenwinged Teal on playa lakes in Texas. Journal of Wildlife Management 48: 838845.

Rave, D. P. and G. A. Baldassarre. 1989. Activity budget of Green-winged Teal wintering in coastal wetlands of Louisiana. Journal of Wildlife Management 53: 753-759.

Reese, J. G. 1975. Productivity and management of feral Mute Swans in Chesapeake Bay. Journal of Wildlife Management 39: 280-286.

SAS Institute, Inc. 2001. SAS/STAT software. Cary, North Carolina.

Sears, J. 1989. Feeding activity and body condition of Mute Swans Cygnus olor in rural and urban areas of lowland river system. Wildfowl 40: 88-98.

Sedinger, J. S. 1997. Adaptations to and consequences of an herbivorous diet in grouse and waterfowl. Condor 99: 314-326.

Sousa, C. 2005. Assessing the impact of Mute Swans in the Chesapeake Bay area of Maryland. Thesis, Cornell University, New York, USA.

Turnbull, R. E. and G. A. Baldassarre. 1987. Activity budgets of Mallards and American Wigeon wintering in east-central Alabama. Wilson Bulletin 99: 457464.

Wilmore, S. B. 1974. Swans of the world. Taplinger Publishing Co., New York, USA. 
Table 1. List of activities recorded for Mute Swan time-activity budgets at Chesapeake Bay, Maryland, USA, 2003 and 2004.

General categories of activities

Detailed types of activities

Foraging/Feeding

Dipping with head-neck submersed

Dipping with head-only submersed

Feeding from the water surface

Up-ending (tipping-up/ tilting)

Resting

Standing/sitting on land

Floating on water surface (loafing/

sleeping)

Swimming

Transport/ Locomotion

Self-maintenance

Preening

Neck/ Wing stretching

Wing-flapping

Bathing

Agonistic

Intraspecific (busking/ threat

display)

Interspecific (hissing, flushing away)

Disturbance induced

Becoming alert/ watchful

Treading

Flying 
Table 2. Mean proportions and standard errors of diurnal time budgets by overall social status (i.e., pair and flock) for Mute Swans in the Chesapeake Bay, Maryland, USA during 2004.

\begin{tabular}{|c|c|c|c|c|c|c|c|c|c|c|c|c|}
\hline \multirow{3}{*}{$\begin{array}{l}\text { Social } \\
\text { status }\end{array}$} & \multicolumn{10}{|c|}{ Non- foraging activities ${ }^{1,2}$} & & \\
\hline & \multicolumn{2}{|l|}{ Feeding } & \multicolumn{2}{|c|}{$\begin{array}{l}\text { Swimm- } \\
\text { ing }\end{array}$} & \multicolumn{2}{|c|}{$\begin{array}{l}\text { Self- } \\
\text { maintaining }\end{array}$} & \multicolumn{2}{|l|}{ Resting } & \multicolumn{2}{|c|}{ Aggression } & \multicolumn{2}{|c|}{ Disturbance } \\
\hline & Mean & $\mathrm{SE}$ & Mean & $\mathrm{SE}$ & Mean & $\mathrm{SE}$ & Mean & $\mathrm{SE}$ & Mean & $\mathrm{SE}$ & Mean & $\mathrm{SE}$ \\
\hline Pair & $34.2 \mathrm{Aa}$ & 2.5 & $27.4 \mathrm{Ab}$ & 2.6 & 15.1Ac & 2.6 & 18.9Ac & 2.6 & $2.0 \mathrm{Ad}$ & 2.6 & $2.3 \mathrm{Ad}$ & 2.6 \\
\hline Flock & $45.4 \mathrm{Ba}$ & 1.5 & 21.9Bb & 1.5 & $13.4 \mathrm{Ab}$ & 1.5 & $16.6 \mathrm{Ab}$ & 1.5 & $1.4 \mathrm{Ac}$ & 1.5 & $1.1 \mathrm{Ac}$ & 1.5 \\
\hline Small flock & $42.2 \mathrm{Aa}$ & 3.3 & $21.1 \mathrm{Ab}$ & 3.3 & $10.5 \mathrm{Ac}$ & 3.3 & $23.1 \mathrm{Ab}$ & 3.3 & $2.2 \mathrm{Ac}$ & 3.3 & 0.9Ad & 3.3 \\
\hline Large flock & $60.1 \mathrm{Ba}$ & 3.6 & $13.7 \mathrm{Bb}$ & 3.6 & $12.7 \mathrm{Ab}$ & 3.6 & $12.7 \mathrm{Bb}$ & 3.6 & $0.4 \mathrm{Ac}$ & 3.6 & $0.3 \mathrm{Ac}$ & 3.6 \\
\hline
\end{tabular}




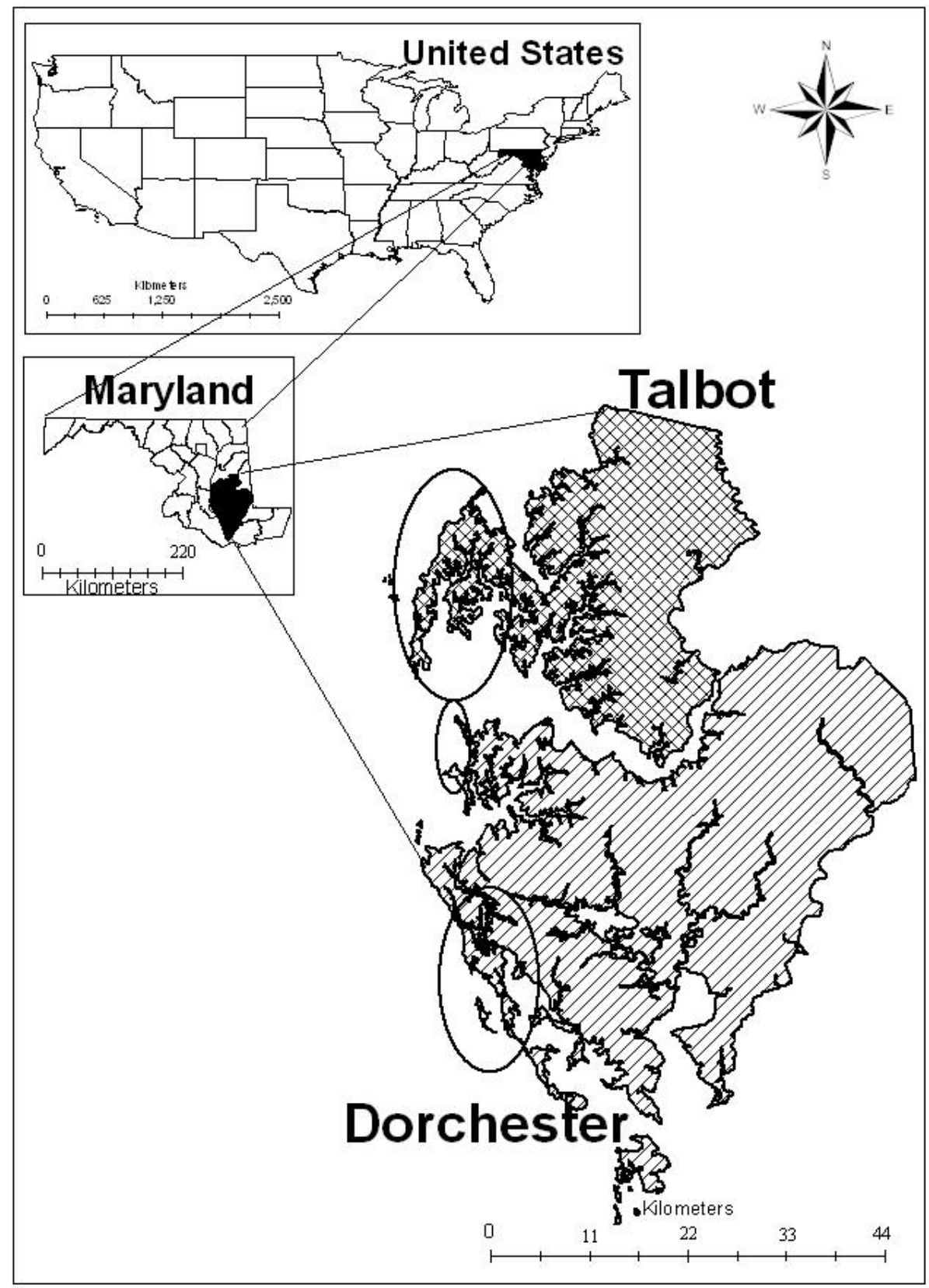

Figure 1. Portions of Talbot and Dorchester Counties (marked) on eastern shore of Chesapeake Bay, Maryland, USA comprised study area for Mute Swan observations 2003 and 2004. 


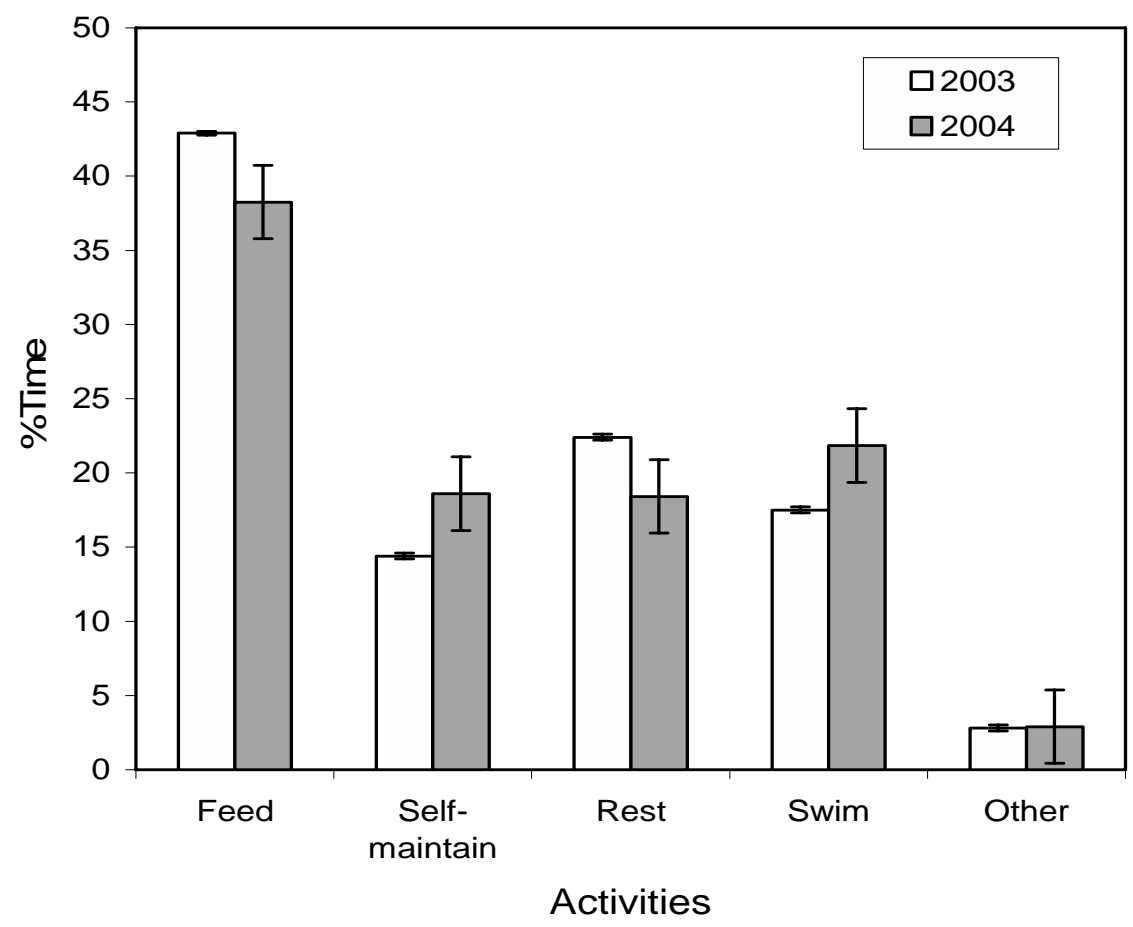

Figure 2. Comparative account of proportion of time spent in feeding and non-foraging activities of Mute Swans in Chesapeake Bay, Maryland, USA during $2003(\mathrm{~N}=50)$ and $2004(\mathrm{~N}=818)$ (Other = agonistic and disturbancerelated activities). 


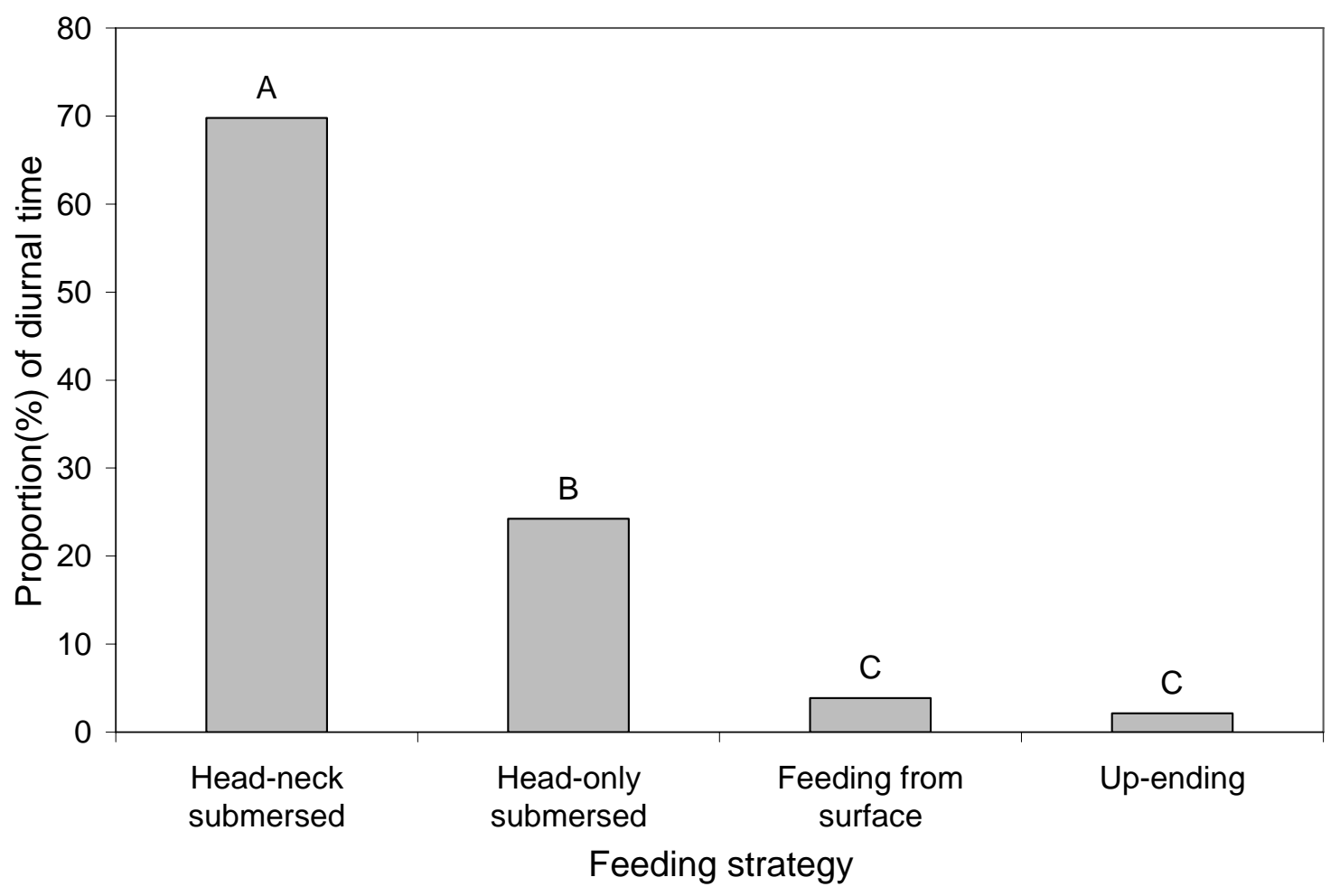

Figure 3. Proportion of time spent by Mute Swans in different feeding strategies at Chesapeake Bay, Maryland, USA during 2004. Time proportions with the same capital letter were not significantly different within feeding strategy type $(\mathrm{P}<0.05)$. 

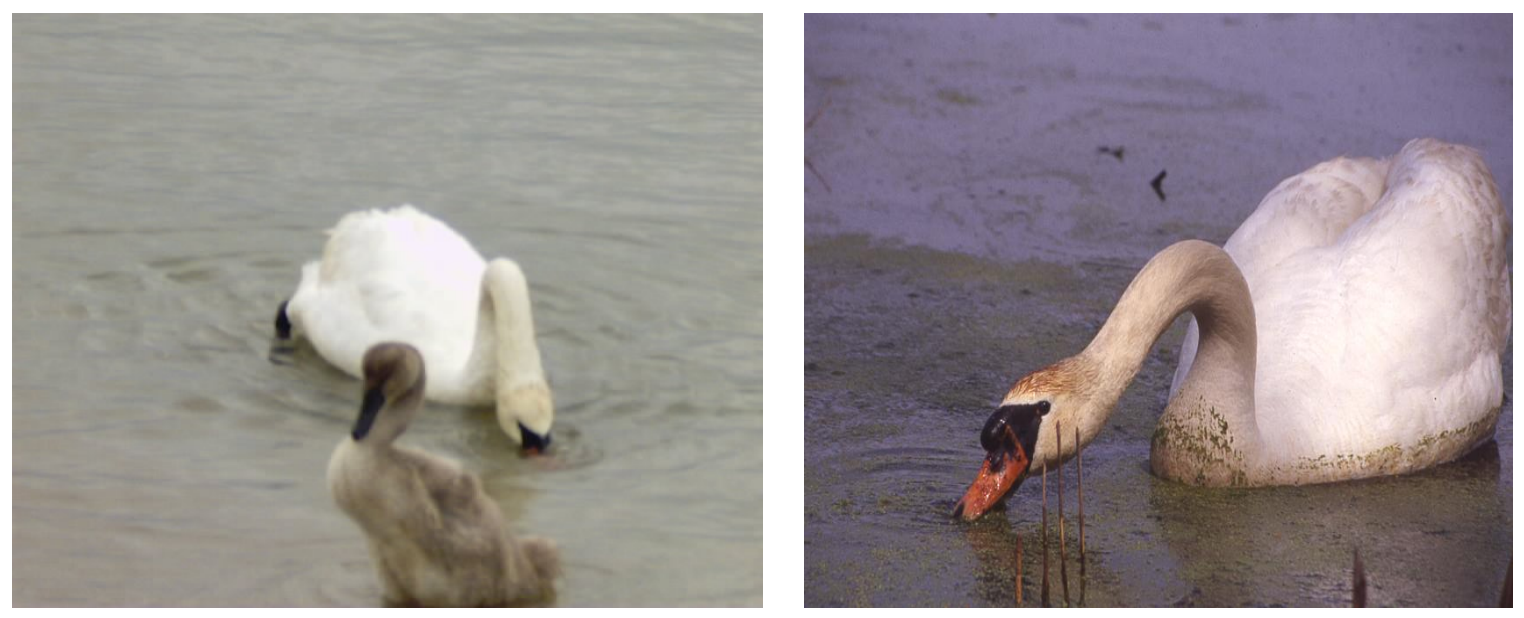

a) Feeding from water surface (adult)
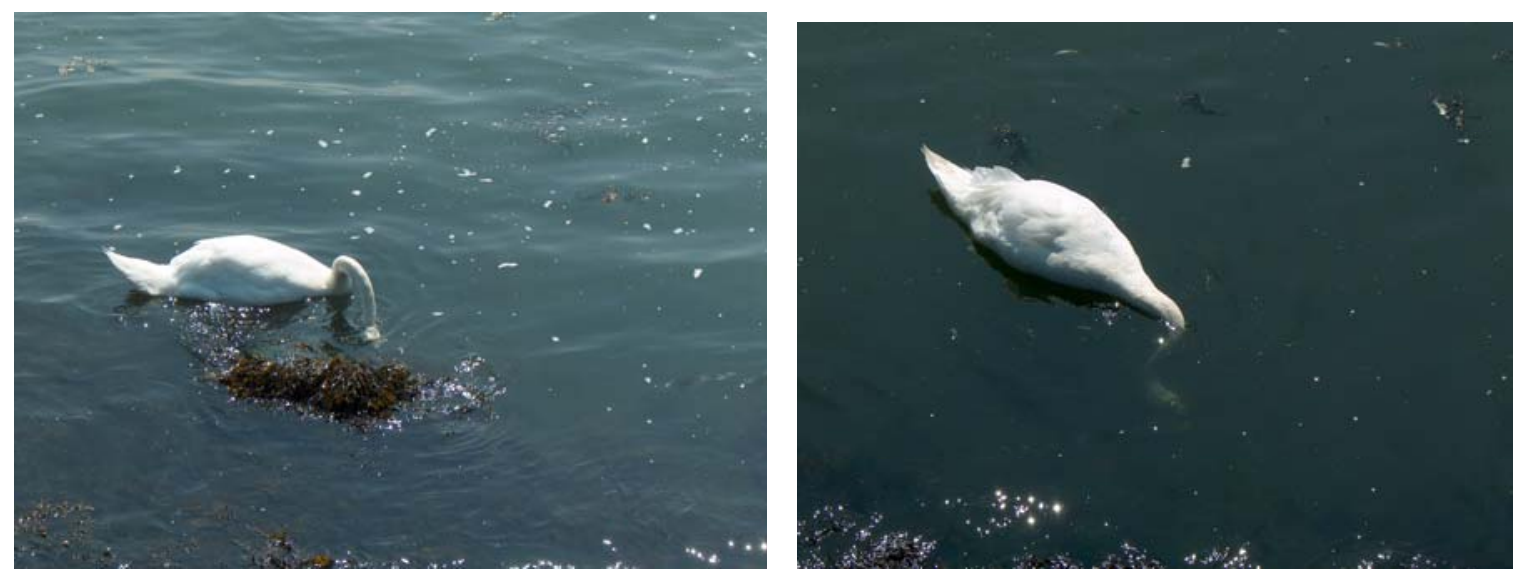

b) Feeding by head-only dipping (Photo: J. T. Anderson)

c) Feeding by head-and-neck dipping (Photo: J. T. Anderson)

Figure 4. Feeding strategies of Mute Swans in the Chesapeake Bay. 

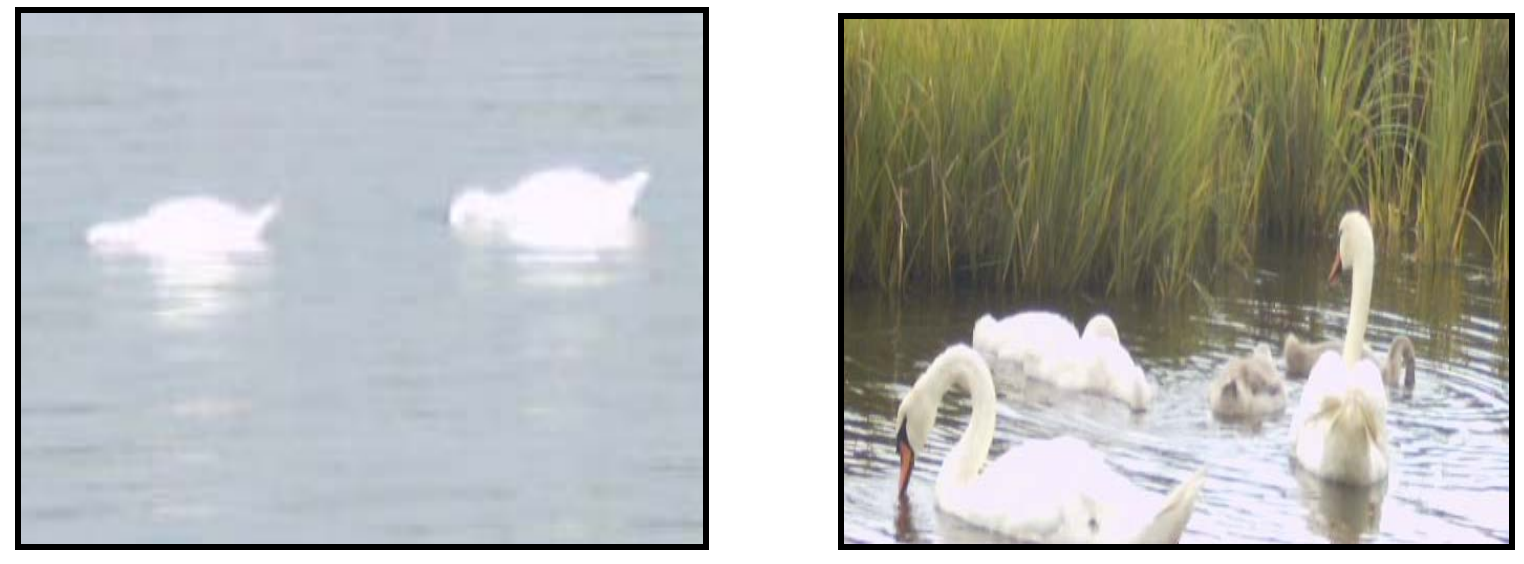

a) Paired Mute Swans feeding with/without cygnets in the Chesapeake Bay, Maryland.
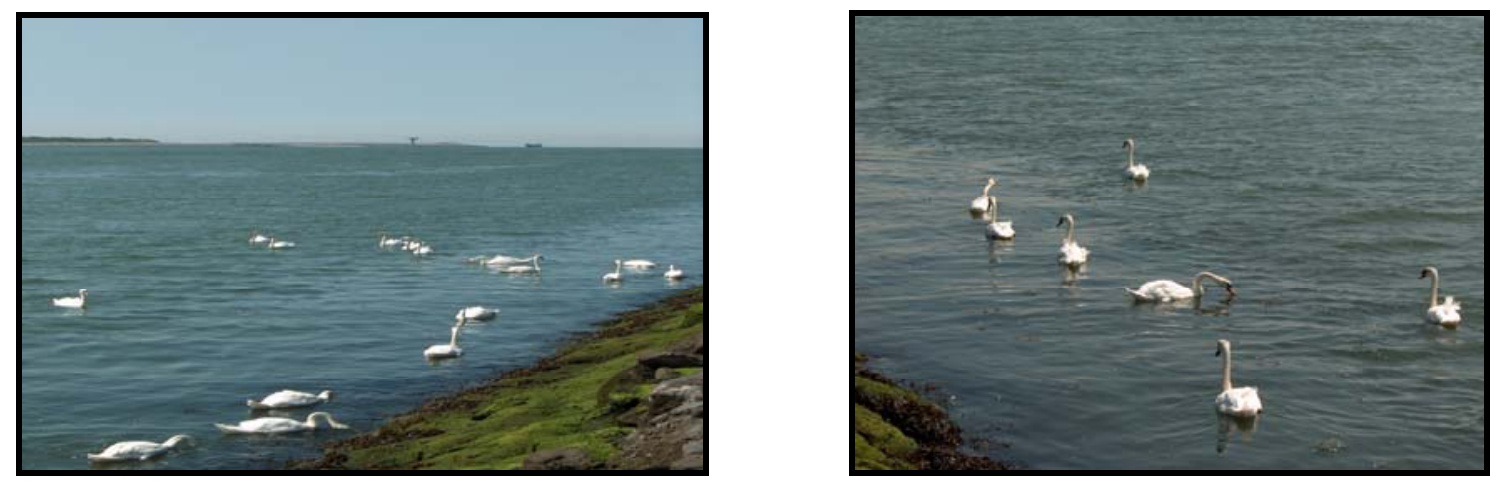

b) Mute Swans in non-breeding flocks feeding on Submerged Aquatic Vegetation. (Photos: J. T. Anderson)

Figure 5. Social affinities of Mute Swans while feeding in the Chesapeake Bay. 


\title{
CHAPTER III
}

2 April 2006

Ketan S. Tatu

Division of Forestry and Natural Resources, West Virginia University

P. O. Box 6125, Morgantown, WV 26506-6125

Phone: 304-685-2244

Fax: 304-293-2441

Email: ktatu@mix.wvu.edu

\section{INVASIVE HERBIVORY: A CASE STUDY OF MUTE SWANS AND SUBMERGED AQUATIC VEGETATION IN CHESAPEAKE BAY}

\author{
KETAN S. TATU ${ }^{1}$, JAMES T. ANDERSON ${ }^{1}$, LARRY J. HINDMAN ${ }^{2}$ \\ AND GEORGE SEIDEL ${ }^{3}$ \\ ${ }^{1}$ Division of Forestry and Natural Resources, West Virginia University, P.O. Box 6125, \\ Morgantown, WV 26506, USA \\ ${ }^{2}$ Maryland Department of Natural Resources, 828B Airpax Road, Wildlife and Heritage \\ Service, Cambridge, MD 21613, USA \\ ${ }^{3}$ Department of Statistics, West Virginia University, P.O. Box 6330, \\ Morgantown, WV 26506, USA
}


Abstract. Mute Swans (Cygnus olor) are poorly studied despite their potential to impact submerged aquatic vegetation (SAV). We measured vegetation characteristics (i.e., percent cover, shoot density, and canopy height) of SAV beds in controls (unfenced), 2year exclosures, and 1-year exclosures at 18 sites in the Chesapeake Bay, Maryland, USA to quantify the impact of herbivory by Mute Swans on SAV during 2003 and 2004. Mute Swan herbivory had a substantial adverse impact on percent cover, shoot density, and canopy height of SAV. At the end of the study mean percent cover, shoot density, and canopy height in the controls were lower by $79 \%, 76 \%$, and $40 \%$ respectively as compared to those in 2-year exclosures. During 2004, percent cover, shoot density, and canopy height increased by $26 \%, 15 \%$, and $22 \%$ respectively between early and late seasons of SAV growth in exclosures, but decreased by $36 \%, 41 \%$, and $18 \%$ in the controls. Six of 7 moderate-depth sites $(0.76-0.99 \mathrm{~m})$ were predominantly occupied by paired Mute Swans and these sites experienced less (i.e., $32 \%$ to $75 \%$ ) SAV reduction. All $(n=7)$ shallow water sites $(0.50-0.75 \mathrm{~m})$ were predominantly occupied by Mute Swan flocks and percent cover reduction of SAV was as high as $75 \%$ to $100 \%$ at these sites. Three of the 5 deep water sites $(\geq 1 \mathrm{~m})$ and 1 of 7 moderate-depth sites also were predominantly occupied by Mute Swan flocks, wherein considerable (i.e., $77 \%$ to $93 \%$ ) SAV reduction was recorded. Thus, considering that flocks are more detrimental to SAV as compared to paired Mute Swans, we recommend that emphasis primarily be placed on controlling Mute Swans population in flocks, and secondarily on pairs.

Key words: Chesapeake Bay; Cygnus olor; exclosure study; exotic; invasions; Mute Swan; Ruppia maritima; Submerged Aquatic Vegetation; SAV; widgeon grass.

This chapter is written in the style of Ecological Applications. 


\section{INTRODUCTION}

Herbivory affects the structure and function of ecosystems (Trlica and Rittenhouse 1993). Though both aquatic and terrestrial ecosystems are affected by herbivory, its impact is greater on aquatic ecosystems as the percentage of primary production consumed by herbivores tends to be higher in aquatic than in terrestrial systems (Just and Lartigue 2004). Herbivores alter plant productivity, distribution, and overall community structure in sea grass estuaries (Behm and Boumans 2001).

Vertebrate herbivores have a major impact on wetland plant communities (Brinson et al. 1981, Barry et al. 2004). In aquatic ecosystems, vertebrate herbivores can affect the stand structure (i.e., stem and shoot density and height) and reduce biomass (Johnson and Foote 1997, 2005). Thus, in the absence of nutria (Myocastor coypus) herbivory, American bulrush (Schoenoplectus americanus) doubled in height, while the stem-density increased by as much as five-fold (Johnson and Foote 2005). Large herbivores, such as birds, could potentially have a dramatic effect on biomass due to their ability to consume large amount of vegetation (Qvarnemark and Sheldon 2004). Waterfowl (Anatidae) of the sub-family Anserinae are one of the significant vertebrate herbivore groups considering their potential to remove vegetation from an aquatic ecosystem. Though they feed on terrestrial vegetation to a varying extent, aquatic macrophytes constitute a substantial part of their diet as geese regularly feed by grubbing in marshes (Ogilvei 1978) and swans regularly feed on submerged aquatic vegetation (SAV) (Johnsgard 1978). Waterfowl have a comparatively higher metabolic rate (Thayer et al. 1984) and in turn, a higher feeding rate. Anserinae species are no exception and therefore, grazing by them removes not only plant biomass, but also the future reproductive potential of those plants (Mitchell and Wass 1996). Although much less 
was known about grazing on aquatic macrophytes by large herbivores in the past (Mitchell and Wass 1996), interactions between herbivorous waterfowl and aquatic macrophytes have become a recent focus in studies of macrophyte dynamics (Lodge et al. 1988, Lodge 1991, Mitchell and Wass 1996, Clevering and van Gulik 1997, Esselink et al. 1997, Perrow et al. 1997) and in studies of habitat use by waterfowl (Mitchell and Perrow 1998, Van Donk 1998, Corti and Schlatter 2002, Santamaria and Rodriguezgironés 2002, La Montagne et al. 2003, Nolet 2004).

Studies on waterfowl herbivory in North America have mainly emphasized native birds (e.g., Snow Geese [Chen caerulescens], Canada Geese [Branta canadensis], Brants [B. bernicla], and Trumpeter Swans [Cygnus buccinator]) (Smith and Odum 1981, Kerbes et al. 1990, Conover and Mesier 1996, Herzog and Sedinger 2003, La Montagne et al. 2003, Person et al. 2003, Sherfy and Kirkpatrik 2003). Similar studies on exotic herbivorous waterfowl are limited, not only because most exotic bird species in North America are poorly studied (Temple 1992), but also because there are few exotic waterfowl species in North America.

One such exotic species is the Mute Swan (Cygnus olor) (Conover and Kania 1994). Mute Swans are native to Eurasia (Ciaranca et al. 1997) and since their introduction into the United States in the late 1800s, they have increased to over 14,000 birds in the Atlantic Flyway (Atlantic Flyway Council 2003). This exotic species is considered feral and invasive (Allin and Husband 2003, Hindman and Harvey 2004). Established populations breed along the northeastern Atlantic Coast, in the Great Lakes region, and in the Pacific northwest (Ciaranca et al. 1997). Chesapeake Bay in Maryland has been a stronghold of Mute Swans in the Atlantic Flyway since the 1990s. Mute Swans have undergone phenomenal population growth in the Chesapeake Bay, where 
their numbers increased from 5 individuals in 1962 to about 4,000 individuals in 1999 (Hindman and Harvey 2004).

As an exotic, feral species, Mute Swan's effects on native ecosystems and species are of concern (Ciaranca et al. 1997). One of the concerns is aggressive interaction (i.e., attacking, injuring, or killing) between territorial pairs of Mute Swans and native waterbirds (Hindman and Harvey 2004). Moreover, disturbance of nesting colonies of native waterbirds by flocks of non-breeding swans also constitutes a matter of concern (Therres and Brinker 2004). However, a more serious problem may be their impact on SAV. Large flocks of unsuccessful breeding and non-breeding swans concentrate in shallow areas of the Chesapeake Bay to molt flight feathers. During this period, these flocks are capable of removing great quantities of SAV (Allin and Husband 2003). Mute Swans can dislodge SAV by paddling and raking the substrate, and additional SAV which is not eaten is destroyed and uprooted (Owen and Kear 1972, Birkhead and Perrins 1986, Hindman and Harvey 2004). Sometimes this is done to provide food for cygnets. At high densities, Mute Swans can overgraze an area, causing a substantial decline in SAV at the local level (Cobb and Harlin 1980, Mountford 2004, Hindman and Harvey 2004).

Submerged aquatic vegetation is a key component of the Chesapeake Bay ecosystem and it provides a major food source for a number of native waterfowl like Redheads (Aythya americana) and Canvasbacks (A. valisineria), mammals like muskrats (Ondatra zibethicus) and beavers (Castor canadensis), and a variety of fish and invertebrates (Allin 1981, Hurley 1990, Ciaranca et al. 1997, Naylor 2004, Perry et al. 2004). Despite the potential of this over-abundant and invasive swan to impose adverse impacts on SAV, quantitative data on reduction of aquatic macrophytes by Mute Swans 
are limited (Hindman and Harvey 2004) even for their stronghold area in North America (i.e., Chesapeake Bay, Maryland).

Although much is known about Mute Swan in Europe where it is a native species, its long-term effects on wetland habitats in North America have yet to be examined (Ciaranca et al. 1997). Specifically, knowledge about the actual impact of Mute Swans on habitats of native waterfowl in North America is limited (Allin and Husband 2003). In North America, significant breeding populations of feral Mute Swans not only occur in about 10 states of the United States that are located in the Atlantic Flyway (Atlantic Flyway Council 2003), but they also exist in Michigan, Minnesota, and Wisconsin (Conover and Kania 1994). Moreover, they also occur in parts of Canada and their numbers have been increasing in many areas in the United States and Canada (Allin 1981, Conover and Kania 1994, Ciaranca et al. 1997, Scott 2004). Therefore, it is important to document or quantify their impact on native macrophytes. Such studies also have global significance as biological invasions are now recognized as one of the most pressing forms of global change (Vitousek et al. 1996), having profound ecological and economic costs (Pimentel et al. 2000). A study of Mute Swan herbivory in the Chesapeake Bay, Maryland also can provide evidence for impacts in other areas of North America.

Our research was designed to answer 3 questions: (1) Does herbivory by Mute Swans result in reduced percent cover, density, and height of SAV? (2) Does the impact of Mute Swan herbivory vary according to depth of water? and (3) Does the impact of the herbivory vary according to social status (pair vs. flock) of Mute Swans? Our primary hypothesis was that Mute Swans, owing to their predominantly herbivorous diet and destructive foraging methods can cause significant reduction in SAV. Our research may 
further help in predicting the consequences of herbivory by Mute Swans in different parts of North America. It also may be beneficial for the research and management of other species of swans in other parts of the world (e.g., Black Swans [Cygnus atratus] in New Zealand [Mitchell and Wass 1996] and Black-necked Swans [Cygnus melancoryphus] in Chile [Corti and Schlatter 2002]).

\section{METHODS}

\section{Study Sites}

We conducted this study on the eastern shore of Chesapeake Bay, Maryland, USA. The Bay is formed by over 150 rivers and streams, and tidal waters of the Atlantic Ocean. It is one of the primary waterfowl wintering areas in the Atlantic Flyway, supporting $40 \%$ of the wintering waterfowl in the Flyway (Hindman and Stotts 1989, Meyers et al. 1995).

Chesapeake Bay is an $8-48 \mathrm{~km}$ wide and $288 \mathrm{~km}$ long shallow estuary that lies in a north-south direction, roughly parallel to the Atlantic seacoast and is mainly covered with clay-silt sediments (Lippson 1973, Meyers et al. 1995). The study area covered 18 sites in the mid-bay (8 in Talbot County and 10 in Dorchester County) (Fig. 1) that were located between $38^{\circ} 25^{\prime} 00^{\prime \prime} \mathrm{N}$ and $38^{\circ} 52^{\prime} 30^{\prime \prime} \mathrm{N}$ latitude and $76^{\circ} 07^{\prime} 30^{\prime \prime} \mathrm{W}$ and $76^{\circ} 22^{\prime}$

30" W longitude. It had meso-haline water with salinity ranging from 5-18 ppt (Lippson 1973, Hurley 1990, Maryland DNR 2005a) and was endowed with SAV beds (Orth et al. 2001; Maryland DNR 2005a) and Mute Swan flocks and pairs during our study period (2003-2004). Widgeon grass (Ruppia maritima), a species of SAV having a wide tolerance to salinities was abundant, whereas the species having less tolerance to high salinity (i.e., horned pondweed [Zannichellia palustris], slender pondweed [Potamogeton 
pusillus], and sago pondweed [Stuckenia pectinata]) were uncommon in our study area (Hurley 1990, Orth et al. 2003).

Although Chesapeake Bay traditionally has played a vital role in providing habitat to wintering native waterfowl, it is inhabited by thousands of resident Mute Swans since the 1990s specifically, in Dorchester (1,638 swans) and Talbot (1,023 swans) Counties. They are the predominant waterfowl in the study area, especially between May and September, when SAV is growing.

\section{Exclosure Experiment}

In May 2003, at the onset of spring SAV growth, we delineated 3 sets of three $5 \mathrm{x}$ $5 \mathrm{~m}$ study plots at each of the 18 study sites. Because SAV density varied, we placed each set of 3 plots in areas of relatively equal density levels which we judged qualitatively at the time of plot establishment. Water level was usually shallow enough (i.e., average $0.7 \mathrm{~m}$ ) for us to judge the relative density by randomly laying $1 \mathrm{~m}^{2}$ quadrats in SAV beds and inspecting SAV growth inside them with our eyes and hands.

However, we also employed snorkeling at deeper water sites $(n=4)$ if high tide occurred at the time of exclosure establishment. Each set of 3 plots contained 1 control (i.e., no exclusion of swans), one 2-year exclosure (i.e., swans excluded from May to August 2003 and 2004), and one 1-year exclosure (i.e., swans excluded from May to August 2004). Therefore, at each study site, we placed 9 plots (i.e., 3 controls, three 2 -year exclosures, and three 1-year exclosures). We set the distance between each type of sampling plot at 10 to $25 \mathrm{~m}$ to ensure that all the plots were in the same SAV bed and had similar relative density. 
We only wanted to exclude Mute Swans from our treatment plots, but still allow access by other organisms (e.g., fish, invertebrates, turtles, cow-nose rays [Rhinoptera bonasus]) that might consume or destroy SAV in our treatment plots. We constructed plots this way to avoid an ambiguity whether a significant fencing effect was due solely to the Mute Swans, or also due to the activities of non-target species. We wanted to prevent submergence of the fence in water due to the tidal action in the Bay to prevent Mute Swans from entering the exclosures under all tidal conditions and to avoid accumulation of floating material (e.g., uprooted SAV) that might shade SAV within the exclosures and influence its growth. To address these 2 challenges, we designed exclosures comprised of four $3.3 \mathrm{~m}$ long metal poles ( $2.54 \mathrm{~cm}$ diameter) that were erected in the bottom mud at 4 corners of the $5 \times 5 \mathrm{~m}$ treatment plot. We put 2 cylindrical buoys $(28 \mathrm{~cm} \times 15 \mathrm{~cm})$ one above the other along each pole of all treatment plots that would freely slide along the pole with changes in tide level. By winding a bright scarlet colored nylon twine having $2 \mathrm{~mm}$ diameter around each buoy on all 4 corner poles, we prepared a 2-strand fence for each treatment plot that moved up and down with the tides. We left a gap of $30-45 \mathrm{~cm}$ between the lower twine and water surface, which was sufficient to allow access by underwater aquatic life into the exclosures (i.e., we observed cow-nose rays, fish, crabs, and turtles in the exclosures). Moreover, the sliding action of the buoys (with nylon twines around them) along the corner poles prevented submergence of the nylon twines during high tide, as at least the upper twine always remained above the water surface. Two strands of bright scarlet colored twine were sufficient to prevent Mute Swans from entering the treatment plots. We also tied 2 strands of nylon twine at the top of 2 diagonally opposite corner poles, making an ' $\mathrm{X}$ ' configuration at the top of each exclosure. This helped in eliminating any 
possibility of swans or other waterfowl flying into the exclosure. During our field work in 2003 and 2004, we never saw Mute Swans or any other waterfowl inside our exclosures, though we often saw cow-nose rays in them. Thus, we believe the fencing was sufficient to create an effective barrier against Mute Swan entry into our exclosures.

\section{SAV Sampling}

We identified submerged macrophytes using Hurley (1990) and an on-line Bay grass guide (Maryland DNR 2005b). We maintained a site-wise record of species and preserved voucher specimens.

We carried out measurements of SAV during the late season of SAV growth in 2003 in 162 sampling plots (i.e., 54 2-years exclosures, 54 1-year exclosures, and 54 2years open plots). In 2004, we measured SAV once during the early season (mid-May to early June) and once again in late season (August) of SAV growth. At each plot, we obtained percent cover, shoot density, and canopy height of SAV. To conduct SAV measurements, we further partitioned each 5 x $5 \mathrm{~m}$ plot into $1 \times 1 \mathrm{~m}$ sub-plots for SAV sampling. Thus, each exclosure or open plot had 25 sub-plots of 1 x $1 \mathrm{~m}$ size. We sampled SAV in 3 diagonally arranged sub-plots in a northeast-southwest fashion (Fig. 2). The diagonal configuration for SAV sampling was followed at all the sites to avoid field-based bias in selecting the sub-plots for SAV sampling. Moreover, by keeping the sub-plots in the center of the exclosures, we eliminated any effects of Mute Swans feeding in the exclosures from the outside or the effects of droppings (i.e., nutrients) from other birds potentially perching on the poles or twines.

In each sub-plot, we laid a $0.1 \mathrm{~m}^{2}$ quadrat $(0.2 \mathrm{~m} \times 0.5 \mathrm{~m})$ on 4 sides and the center to get an average value of SAV \% cover for the sub-plot. We later determined the 
average value for an entire sampling plot by averaging SAV cover values for the 3 diagonal sub-plots. As per cent cover estimation had to be conducted at the surface of the bottom mud that was up to $1 \mathrm{~m}$ below the surface of water that was often turbid, we estimated the amount of cover by judging the proportion of SAV cover inside the quadrat with our hands and through visual assessment when practical. For judging percent cover of SAV, we divided the quadrat into 4 equal sections with the help of twines. To increase the accuracy of SAV percent cover judgment in water, we further sub-divided each of these 4 sections with a twine to represent $12.5 \%$ of the quadrat area and a few of them also were sub-divided to represent $6.25 \%$ of the total area. We assigned the estimated cover into 1 of 6 cover classes (Daubenmire 1959, Table 1). The mid-point of each class was used in analysis.

We measured and recorded density of SAV by species in each sampling plot by laying a $1 \times 1 \mathrm{~m}$ quadrat (each divided into $0.1 \times 0.1 \mathrm{~m}$ squares) in each of the three $1 \times 1$ m subplots. We counted the number of shoots of SAV in each sub-plot in 25-50 randomly selected $0.1 \times 0.1 \mathrm{~m}$ squares. If there was not significant variation in the number of individuals encountered from square to square, we projected density estimates (shoots $/ \mathrm{m}^{2}$ ) for the entire $1 \mathrm{~m}^{2}$ frame. We counted them in up to $75-100$ squares, if significant variation was encountered in the number of individuals from each square.

We measured leaf height of SAV for each species using a ruler to the nearest 5 $\mathrm{mm}$. To measure canopy height, we grabbed a large handful of rooted plants in randomly selected $0.1 \times 0.1 \mathrm{~m}$ squares (Durate and Kirkman 2001). By extending leaves to their maximum height, we measured height up to the top of the bundle from the base with a ruler. 
We measured the maximum water depth at each study site during high tide on the day of SAV measurements. We measured the depth to the nearest $1 \mathrm{~cm}$ on a permanently marked pole and categorized sites as shallow (i.e., $0.5 \mathrm{~m}$ to $0.75 \mathrm{~m}$ ), moderate (i.e., 0.76 m to $0.99 \mathrm{~m}$ ), or deep (i.e., $\geq 1 \mathrm{~m}$ ).

\section{Waterbird Sampling}

We recorded presence or absence of pairs and flocks along with the numbers of Mute Swans and other waterbirds every 2 weeks at each site during the SAV growing season ([May to August] 2003, 2004). We conducted the counts during 3 time blocks, i.e. between 6:00 and 11:00 hours, between 12:00 and 15:00 hours, and between 16:00 and 19:00 hours. We counted waterbirds individually in a 6-7 ha area at each site. This counting area was twice the area covering all 3 sets of sampling plots and its immediate environs. The area of all the sets of sampling plots was taken approximately equal to the average territory size (i.e., 3-3.5 ha) of Mute Swans at the Bay (Ciaranca et al. 1997, Hindman and Harvey 2004).

\section{Statistical Analysis}

We conducted Analysis of Variance (ANOVA) (fixed effects model) using Generalized Linear Models (GLM) in SAS version 8 (SAS Institute 2001) to assess the effects of Mute Swan herbivory on SAV during the early and late seasons of SAV growth among the 3 treatments in 2004 . We used \% cover, shoot density, and canopy height as dependent variables indicating SAV status and quantified SAV status using least square means of these 3 variables. We used contrast statements to compare means from 2-year exclosures to means from controls; means from 2-year exclosures to means from 1-year 
exclosures and means from 1-year exclosures to means from controls. Significance for all statistical inferences was $P \leq 0.05$.

We used ANOVA to test for differences in percent cover, shoot density, and canopy height among shallow, moderate, and deep water areas. We also assessed the effect of social status (pair and flock) on these variables. The ANOVA used a 2-factor model with social status and water depth (categories as explained above) as treatments.

\section{RESULTS}

At the end of our exclosure experiment (i.e., after 2 consecutive growing seasons of SAV) percent cover, density, and height of SAV were greater in the sampling plots protected from swan herbivory than those remained exposed to it (Fig. 3). Widgeon grass was the only SAV species sampled at 13 of the $18(72 \%)$ sampling sites. A horned pondweed-widgeon grass association was encountered at 5 study sites (i.e., Claiborne Harbor, Punch Point, Osprey Point, Middle Point Road, and Haven on the Bay). Overall, $94 \%$ of the total percent cover in our sampling plots was widgeon grass and only $6 \%$ was horned pondweed (Appendix II).

SAV cover .- Mean percent cover of SAV in controls (Table 2) was 79\% less than that in 2-year exclosures and $69 \%$ less than that in 1-year exclosures at the end of the 2004 growing season $\left(F_{1,51}=44.35, P<0.001\right)$. One-year exclosures had $41 \%$ less cover as compared to that inside the 2-year exclosures $\left(F_{1,51}=8.97, P=0.004\right)$.

Percent cover of SAV in 2-year exclosures increased by $26.4 \%$ from the early to late SAV growing season during $2004\left(t_{34}=2.32, P=0.026\right)$ (Fig. 4). It increased in 1year exclosures by $21.6 \%$ during the same time period $\left(t_{34}=1.61, P=0.116\right)$. Unlike in 
1-year and 2-year exclosures, the extent of SAV decreased in controls by $35 \%$ from the early to late season in $2004\left(t_{34}=1.53, P=0.135\right)$ (Fig. 4).

SAV density. - Mean shoot density of SAV in the controls (Table 2) was $76 \%$ less than that in 2 -year exclosures and $57 \%$ less than that in 1-year exclosures $\left(F_{1,51}=\right.$ 45.90, $P<0.001)$. The 1-year exclosures had $45 \%$ less SAV density as compared to that inside the 2-year exclosures $\left(F_{1,51}=15.89, P<0.001\right)$.

Shoot density of SAV increased by $15 \%$ in the 2 -year exclosures $\left(t_{34}=1.57, P=\right.$ $0.125)$ and by $14 \%$ in the 1 -year exclosures $\left(t_{34}=0.8, P=0.430\right)$ between the early and late measurements of SAV in 2004. In the open plots SAV shoot density decreased by $41 \%\left(t_{34}=1.98, P=0.051\right)($ Fig. 4$)$.

SAV height. - Mean canopy height of SAV in controls (Table 2) was $40 \%$ less than that in 2-year exclosures and $32 \%$ less than that in 1-year exclosure plots $\left(F_{1,51}=\right.$ 81.96, $\mathrm{P}<0.001)$. Moreover, 1 -year exclosures had $12 \%$ less SAV cover as compared to that inside the 2-year exclosures $\left(F_{1,51}=7.98, P=0.007\right)$.

Canopy height of SAV in 2-year exclosures increased by $21.7 \%$ between the early and late growing seasons of SAV in $2004\left(t_{34}=6.09, P<0.001\right)$. It also increased by $30 \%$ in 1 -year exclosures $\left(t_{34}=6.96, P<0.001\right)$. Contrarily, in the control plots, it decreased by $17.6 \%$ during the same time period $\left(t_{34}=4.30, P=0.001\right)$ (Fig.4).

Effect of social status and water depth on SAV reduction. - The water depth class $\times$ social status category interaction was significant $\left(F_{1,13}=3.71, P=0.039\right)$. Three of the 5 deeper water sites (depth $\geq 1 \mathrm{~m}), 1$ of 7 moderate-depth sites $(0.76 \mathrm{~m}-0.99 \mathrm{~m})$, and all $(n=7)$ shallower water sites were predominantly occupied by Mute Swan flocks; the other sets had more swans in pairs than flocks (Table 3). Consequently, SAV percent cover reduction at these shallow water sites was high $[90 \% \pm 3.40($ mean $\pm 1 \mathrm{SE})]$, 
ranging from 75\% (Tar Bay area) to 100\% (Wades Point and Bay Shore areas) (Table 3). There were no significant differences in SAV reduction between deep and moderatedepth and shallower water sites occupied by flocks $\left(F_{1,13}=0.06, P=0.806\right)$. Thus, we found that flocks caused considerable SAV reduction at moderate-depth $(93 \% \pm 0.00)$ and deeper water $(83 \% \pm 4.16)$ sites too [i.e., $77 \%$ (Hill Point Cove) to $93 \%$ (Osprey Point)]. We found a significant difference in SAV reduction between deeper vs. moderate-depth sites occupied by pairs $\left(F_{1,13}=5.35, P=0.038\right)$. The moderate-depth sites which were predominantly occupied by paired Mute Swans had experienced less $(52 \% \pm 8.11)$ SAV reduction [i.e., $32 \%$ (Todd's Point) to $75 \%$ (Twin's Point)], whereas the deeper water sites had experienced more $(92 \% \pm 4.50)$ SAV reduction [i.e., $90 \%$ (Hooper's Island Road Point) and 93\% (at Punch Point)].

Other waterbirds. - We recorded 15 species of waterbirds that shared sites with Mute Swans at our study sites; 13 of them were carnivorous (Table 4). The remaining 2 species Mallard (Anas platyrhynchos) and Canada Goose (Branta canadensis), were omnivorous (Bellrose 1986) and herbivorous (Baldassarre and Bolen 1994), respectively. They occurred in low number [i.e., Mallard: $1.19 \pm 0.68$ (mean \pm 1 SE), Canada Geese: $0.90 \pm 0.47$ ] (Table 4) as compared to that of Mute Swans $(25.00 \pm 1.31)$ in our study area.

\section{DISCUSSION}

Mute Swan herbivory had a negative impact on the vegetative characteristics of submerged macrophyte beds in the Chesapeake Bay, Maryland. Our exclosure experiment documented substantially lower values (i.e., as low as 79\%) of percent cover in controls compared to that in 2-year exclosures. Likewise, shoot density and canopy 
height of SAV also were lower (i.e., by $76 \%$ and $40 \%$ respectively) in controls as compared to those in the 2-year exclosures. Such lower values of SAV characteristic in the controls were due to removal of SAV primarily by Mute Swan herbivory as our exclosure design did not exclude grazing by the non-target organisms except other waterbird species. Moreover, most of the other waterbird species $(n=15)$ sharing the experimental sites did not have the potential to cause SAV decline because they were carnivorous $(n=13)$. Two species of waterfowl (i.e., Mallard [an omnivore] and Canada Goose [a herbivore]) could feed on SAV, but they occurred in low numbers (Table 4) leaving little possibility of substantial SAV consumption. A possible reason for less of an effect of herbivory on canopy height compared to that on percent cover and shoot density was the way Mute Swans feed on SAV. Mute Swans often pull and consume intact plants rather than feeding on only parts of plants, as do native waterfowl (Fox 1996, Naylor 2004).

Several waterfowl-macrophyte interaction studies conducted in the past have shown that waterfowl significantly reduce submerged and emergent macrophytes during the growing season (Smith and Odum 1981, Corti and Schlatter 2002). Such published studies specifically regarding Mute Swans are few (Clevering and van Gulik 1997, Allin and Husband 2003). In tidal area of the southwest part of the Netherlands, Mute Swan grazing for 3 consecutive growing seasons resulted in the complete disappearance of an emergent aquatic macrophyte (i.e., Common Club-rush [Scirpus lacustris]) (Clevering and van Gulik 1997). Mute Swans, along with Mallards and American Coots (Fulica atra), severely affected sago pondweed abundance at shallow sheltered sites adjacent to Asko Island, in the northern Baltic (Idestam-Almquist 1998). 
An exclosure study of Mute Swan herbivory in coastal ponds in the United States [i.e., at Little Compton, Rhode Island (Allin and Husband 2003)] documented considerable (i.e., 95\%) reduction in SAV biomass in control (open) plots as compared to that in the treatment plots (exclosures) at the end of 2 years (Allin and Husband 2003). Though we measured different SAV parameters (i.e., percent cover, shoot density, and canopy height) instead of SAV biomass, we too revealed lower values of those parameters in the controls (Table 2, Appendix I) indicating SAV decline. The only other exclosure based study in the USA to assess the impact of Mute Swan herbivory on SAV was conducted in Connecticut (Conover and Kania 1994). The study was conducted in freshwater ponds $(n=15)$ and documented slightly higher amount of SAV in the exclosures as compared to that in the grazed plots. However, the difference was not statistically significant (Conover and Kania 1994). The potential reason for an insignificant difference in the amount of SAV between control and treatment plots in the Connecticut-based study was the low swan population $(n=30$ swans $)$ at the sites under investigation during the years of the study (Conover and Kania 1994). Unlike the Connecticut study, the Mute Swan population at our study sites on the eastern shore of Chesapeake Bay was high $(n=338)$. It also was higher than in the study conducted at the coastal ponds in Rhode Island $(n=279)$ (Allin and Husband 2003).

An important result of our study is that the values of vegetative characteristics of $\mathrm{SAV}$ in 1-year exclosures were lower than those in 2-year exclosures, but higher than those in controls (Table 2). Therefore, we infer that percent cover, shoot density, and canopy height of SAV were proportional to the period (i.e., 1-year vs. 2-year) for which the SAV was exposed to the herbivory. Mute Swans consume SAV in the Bay throughout the year due to their year-round stay on the Bay (Ciaranca et al. 1997). 
Therefore, controls provided the longest exposure of SAV to Mute Swan herbivory leading to the lowest values of SAV parameters, 2-year exclosures facilitated the shortest exposure of SAV to herbivory leading to the highest values of the parameters, and 1-year exclusion of the swans resulted in exposure of SAV to herbivory for an intermediate time period leading to the intermediate values of vegetation characteristics of SAV.

A potential reason for substantial SAV reduction in the controls could be the predominance of widgeon grass, the predominant food source of Mute Swans (Perry et al. 2004) in the study area. Overall, $94 \%$ of the total percent cover of SAV in our sampling plots was widgeon grass (Appendix II). Perry et al. (2004) found that $83 \%$ of all the food contents in the esophagus and proventriculus of Mute Swans $(n=2)$ from the Eastern Bay (where our study sites were located) was widgeon grass. Moreover, $66 \%$ of all the food contents in the gullets of Mute Swans $(n=15)$ at Smith Islands and $89 \%$ of the food contents from the gullets of Mute Swans $(n=6)$ in the South Marsh Island area of the Bay was widgeon grass (Perry et al. 2004). At the coastal ponds on Rhode Island, the swans preferred widgeon grass (over horned pondweed) growing at shallow sites (Allin and Husband 2003).

Widgeon grass is native to the United States. Compared to exotic plant taxa, native taxa are less likely to possess life history traits that allow them to colonize after the disturbance (Howe and Westley 1988, Hurley 1990). Therefore, the species may have a lower tolerance level to the disturbance created by invasive waterfowl herbivory, leading to considerably lower values of percent cover, shoot density, and canopy height in the controls.

A plant's response to herbivory may result in under-compensation, exact compensation, or over-compensation (Nolet 2004). Considering that SAV is a stressed 
resource in the Chesapeake Bay ecosystem (Naylor 2004), the possibility of widgeon grass responding positively to herbivory is unlikely as indicated by our study. Even under normal ecological condition, positive feedback (i.e., over-compensation) of plants in response to herbivory is thought to be insignificant in aquatic systems (Mitchell and Perrow 1998, Nolet 2004).

Though our study demonstrated that Mute Swan herbivory led to a localized reduction in SAV cover, the extent of reduction at each site was influenced by water depth and Mute Swan social status. The study revealed that SAV cover in shallower water was reduced by as much as $100 \%$. Allin and Husband (2003) suggested that the rate of SAV reduction by Mute Swan herbivory was related to water depth. They revealed that Mute Swans reduced biomass by as much as 95\% during 1991-1992 when the water levels were relatively shallow (i.e., $<0.5 \mathrm{~m}$ ). They further noted that, there was a notable decrease in the amount of biomass removed during the remaining period of the study, when water depth increased by 50\%. Though Allin and Husband (2003) suggested that shallower water led to greater SAV reduction due to Mute Swan herbivory, they did not assess the influence of social status (i.e., pair vs. flock) on extent of SAV reduction in shallow water.

In our study we found that Mute Swan herbivory in shallower water resulted in greater SAV reduction because shallow water sites were predominantly occupied by flocks of Mute Swans. The flocks, especially larger ones, are more detrimental to SAV beds than pairs (Cobb and Harlin 1980, Chapter 2). They can overgraze shallow water areas (Hindman and Harvey 2004). We also found that flocks did not restrict themselves to shallower water sites, but to a lesser extent, they also occupied moderate-depth $(0.5 \mathrm{~m}-$ $0.75 \mathrm{~m})$ and deeper water $(\geq 1 \mathrm{~m})$ sites and Mute Swans in the flocks reduced SAV cover 
up to $93 \%$. The likely reason is that an adult Mute Swan can reach SAV under water up to $1.07 \mathrm{~m}$ and can consume 1.8 to $3.6 \mathrm{~kg}$ wet weight of plant material each day (Willey and Halla 1972, Owen and Cadbury 1975, Fenwick 1983).

The occurrence of paired Mute Swans (usually without cygnets) predominantly at moderate-depth sites and to some extent at deeper water sites was an interesting finding. There might be more than one reason for paired Mute Swans having no affinity to shallower water sites. Such sites are susceptible to frequent disturbances and considerable SAV exploitation by flocks of Mute Swans as the latter predominantly occurred at shallow water sites. Moreover, shallower water sites might not be as safe as moderate or deep water sites for the paired Mute Swans and their cygnets with regards to human activities (e.g., crabbing and fishing) and land-based or shallow water predators.

Cover reduction of SAV by paired Mute Swans was typically lower than that by the flocks. Thus, at 5 of the 7 sites occupied by paired Mute Swans, SAV cover reduction was as low as $32 \%$ to $75 \%$ as compared to $75 \%$ to $100 \%$ reduction by the flocks. All of these sites were moderate-depth sites. At 2 deep water sites occupied by pairs, SAV reduction was as high as $90 \%$ to $93 \%$. Greater SAV reduction at deep water site compared to that at moderate-depth sites was probably due to better SAV recovery at moderate-depth sites compared to that at the deep water sites. The extent of light penetration that was measured using a Secchi disk at the moderate-depth sites was higher (i.e., $83 \%$ ) than that at deep water sites (i.e., 53\%). This in turn, might have resulted in better SAV recovery and lesser net reduction in SAV cover at moderate-depth sites. Apart from reduced light penetration, the deeper water sites also might have been influenced by some specific ecological factors operating at these sites, leading to poorer SAV recovery. Thus, one of the deeper water sites (Hooper's Island Road) was unique as 
it was like a small coastal pond formed adjacent to a road and a pair successfully raised cygnets in this small area both during 2003 and 2004 from hatchling stage to juvenile stage resulting in consistent and greater SAV consumption and reduction. Another deep water site that was predominantly occupied by a pair, experienced high SAV decline by occasional flocks of mute swans $(12<n<100)$ during 2003 that might have caused poor SAV recovery by the end of our study.

\section{CONCLUSIONS AND MANAGEMENT IMPLICATIONS}

This exclosure experiment quantitatively showed that Mute Swan herbivory leads to considerable reduction in cover, shoot density, and canopy height of SAV. Thus, it has provided evidence that SAV, a stressed resource in the Chesapeake Bay, undercompensates in response to Mute Swan herbivory. As SAV beds at all our study sites ( $n$ $=18$ ) predominantly consisted of widgeon grass, it is likely that Mute Swan herbivory is detrimental to this native species of SAV. Herbivores (e.g., Mute Swans) can have a large impact on a plant's ability to compete and deal with the physical environment (Janzen 1979). Submerged aquatic vegetation in the Chesapeake Bay is the stressed resource (Naylor 2004), and hence exotic taxon (like Mute Swan) can introduce new forms of disturbance or can enhance the existing disturbance regime (Cushman et al. 2004). Considering that SAV in general, and widgeon grass in particular, have high food value for other wintering waterbirds on the Bay (Stewart 1962), Mute Swan herbivory is undesirable. It also is undesirable considering several other ecological functions performed by SAV in the Bay. Therefore, we recommend that Mute Swan populations should be reduced in the Chesapeake Bay, Maryland. Moreover, our study has shown that flocks, unlike pairs of Mute Swans, can cause up to $100 \%$ SAV cover reduction in 
shallower water. High waterfowl densities cause large reductions in the amount of vegetation (Mitchell and Wass 1996). Thus, considering that flocks are more detrimental to SAV as compared to paired Mute Swans, emphasis should primarily be placed on reducing Mute Swan flocks and secondarily on pairs. To fulfill this task, efforts to remove adult Mute Swans and egg addling must be intensified.

It was the consensus of the Chesapeake Bay Program's SAV Task Group that the continued expansion of the Mute Swan population runs counter to the Vital Habitat Protection and Restoration Section of the Chesapeake Bay Agreement (Naylor 2004). One of the program's goals is to preserve, protect, and restore those habitats and natural areas that are vital to the survival and diversity of the living resources of the Bay and rivers (Naylor 2004). Submerged aquatic vegetation beds are certainly vital to the survival of the living resources of the Bay (Hurley 1990). Therefore the Chesapeake Bay Program has committed significant resources over the past 20 years to determine the best methods for protecting and restoring SAV populations (Chesapeake Bay Program 2004). The large Mute Swan population in the Bay is causing adverse ecological effects, and these effects will increase if the population continues to grow (Hindman and Harvey 2004). Therefore, Maryland DNR believes that the Mute Swan population must be managed at a level that will protect critically important SAV beds, and will allow for restoration of SAV (Hindman and Harvey 2004). We suggest that adult Mute Swans in flocks (especially those in large flocks) should be removed from the Bay for the population management purpose because this study has shown that they are more detrimental to SAV in the Bay. The population should be reduced to less than 500 birds (Atlantic Flyway Council 2003) as when the State's population level was less than 500 birds, adverse ecological impacts and conflicts between people and Mute Swans were 
negligible (Hindman and Harvey 2004). By taking into consideration population reduction target in the Atlantic Flyway (i.e., 3,000 swans by 2013) (Atlantic Flyway Council 2003) and faster annual population growth rate in the Chesapeake Bay as compared to that in the Atlantic Flyway, we suggest to reduce the population of Mute Swans in the Chesapeake Bay to 342 birds by 2013 (Appendix IV). We also suggest studying the impact of Mute Swan herbivory on SAV in the upper and lower portions of the Bay as our study was conducted in the middle portion of the Bay. We recommend to employ our exclosure design as our simple design of exclosures is not only effective in tidal water conditions and against Mute Swans in the Bay, but also relatively maintenance free compared to standard fencing and is cost effective, as it cost about $\$ 25$ for a 5 x $5 \mathrm{~m}$ plot. By using brightly colored buoys for making the sliding fence structure of the exclosures; recreation boaters and commercial crabbers and fishermen can be made aware about the presence of these exclosures from a distance. In turn, any undesirable interaction between people and exclosures can be avoided. Moreover, to avoid any boating hazards, exclosures should not be established in the vicinity of docks or harbors. 


\section{ACKNOWLEDGEMENTS}

Funding for this work was provided by Federal Aid in Wildlife Restoration, grant-W-61-R to Maryland DNR and Maryland Migratory Game Bird Stamp Funds. We thank Andrew Isner, Jon Chandler, Troy Osborne, Joseph Osbourne, Seth Lemley, Dave Helon, and Collin Balcombe of West Virginia University, and Brent Evans of Maryland DNR for field assistance and property owners for allowing access to the Bay. This is scientific article number XXXX of the West Virginia University Agricultural and Forestry Experiment Station. 


\section{LITERATURE CITED}

Allin, C. C. 1981. Mute Swans in the Atlantic Flyway. Proceedings of the International Waterfowl Symposium 4:149-154.

Allin, C. C., and T. P. Husband. 2003. Mute Swans (Cygnus olor) impact on submerged aquatic vegetation and macroinvertebrates in a Rhode Island coastal pond. Northeastern Naturalist 10:305-318.

Atlantic Flyway Council 2003. Atlantic Flyway Mute Swan Management Plan 20032013. Atlantic Flyway Council, Laurel, Maryland, USA.

Baldassarre, G. A., and E. G. Bolen. 1994. Waterfowl ecology and management. John Wiley \& Sons, New York, New York, USA.

Barry, M. J., R. Bowers, and F. A. De Szalay. 2004. Effects of hydrology, herbivory and sediment disturbance on plant recruitment in a Lake Erie coastal wetland. American Midland Naturalist 151:217-232.

Behm, P. M., and R. M. J. Boumans. 2001. Modeling herbivorous consumer consumption in the Great Bay Estuary, New Hampshire. Ecological Modeling 143:71-94.

Bellrose, F. C. 1986. Ducks, geese and swans of North America. Stackpole Books, Harrisburg, Pennsylvania, USA.

Birkhead, M. E., and C. M. Perrins. 1986. The Mute Swan. Croom Helm, London, UK.

Brinson, M. M., A. E. Lugo, and S. Brown. 1981. Primary productivity, decomposition, and consumer activity in freshwater wetlands. Annual Review of Ecology and Systematics 12:123-161.

Chesapeake Bay Program. 2004. Preserving and restoring bay grasses. Maryland Department of Natural Resources, Annapolis, Maryland, USA. 
〈http://www.chesapeakebay.net/restrtn.htm〉.

Ciaranca, M. A., C. C. Allin, and G. S. Jones. 1997. Mute Swan (Cygnus olor). Pages 1-26 in A. Poole and F. Gill, editors. The Birds of North America, No. 273. The Academy of Natural Sciences, Philadelphia, Pennsylvania, USA.

Clevering, O. A., and M. G. van Gulik. 1997. Restoration of Scirpus lacustris and Scirpus maritimus stands in a former tidal area. Aquatic Botany 55:229-246.

Cobb, J. S., and M. M. Harlin. 1980. Mute Swan (Cygnus olor) feeding and territoriality affects diversity and density of rooted aquatic vegetation. American Zoologist 20:882.

Conover, M. R., and G. S. Kania. 1994. Impact of interspecific aggression and herbivory by Mute Swans on native waterfowl and aquatic vegetation in New England. Auk 111:744-748.

Conover, M. R., and T. A. Mesier. 1996. Feeding preferences and changes in mass of Canada Geese grazing endophyte-infected tall fescue. Condor 38:859-862.

Corti, P., and R. P. Schlatter. 2002. Feeding ecology of the Black-necked Swan Cygnus melancoryphus in two wetlands of Southern Chile. Studies on Neotropical Fauna and Environment 37:9-14.

Cushman, J. H., T. A. Tiefny, and J. M. Hinds. 2004. Variable effects of feral pig disturbances on native and exotic plants in a California grassland. Ecological Applications 14:1746-1756.

Daubenmire, R. F. 1959. A canopy coverage method of vegetation analysis. Northwest Science 35:43-64.

Durate, C. M., and K. Kirkman. 2001. Methods for the measurement of sea grass abundance and depth distribution. Pages 141-153 in F. T. Short and R. G. Coles, 
editors. Global sea grass research methods. Elsevier, Amsterdam, The Netherlands.

Esselink, P., G. J. F. Helder, B. A. Aerts, and K. Gerdes. 1997. The impact of grubbing by Greylag Geese (Anser anser) on the vegetation dynamics of a tidal marsh. Aquatic Botany 55:261-279.

Fenwick, G. H. 1983. Feeding behavior of waterfowl in relation to changing food resources in Chesapeake Bay. Dissertation. Johns Hopkins University, Baltimore, Maryland, USA.

Fox, A. D. 1996. Zostera exploitation by Brent Geese and Wigeon on the Exe Estuary, southern England. Bird Study 43:257-268.

Herzog, M. P., and J. S. Sedinger. 2003. Dynamics of foraging behavior associated with variation in habitat and forage availability in captive Black Brant (Branta bernicla nigricans) goslings in Alaska. Auk 121:210-223.

Hindman, L. J., and V. D. Stotts. 1989. Chesapeake Bay and North Carolina Sounds. Pages 27-55 in L. M. Smith, R. L. Pederson, and R. M. Kaminski, editors. Habitat Management for migrating and wintering waterfowl in North America. Texas Tech University Press, Lubbock, Texas, USA.

Hindman, L. J., and W. F. Harvey. 2004. Status and Management of Mute Swans in Maryland. Pages 11-17 in M.C. Perry, editor. Mute Swans and their Chesapeake Bay Habitats: Proceedings of a Symposium: U.S. Geological Survey, Biological Resources Discipline Information and Technology Report USGS/BRD/ITR-2004-0005.

Howe, H. F., and L. C. Westley. 1988. Ecological relationships of plants and animals. Oxford University Press, New York, New York, USA. 
Hurley, L. M. 1990. Field guide to the submerged aquatic vegetation of Chesapeake Bay, U. S. Fish and Wildlife Service, Washington, D.C., USA.

Idestam-Almquist, J. 1998. Waterfowl herbivory on Potamogeton pectinatus in the Baltic Sea. Oikos 81:323-328.

Janzen, D. H. 1979. New horizons in the biology of plant defenses. Pages 331-350 in G. A. Rosenthal and D. H. Jazen. editors. Herbivores-their interaction with secondary plant metabolites. Academic Press, New York, New York, USA.

Johnsgard, P. A. 1978. Ducks, geese, and swans of the world. University of Nebraska Press, Lincoln, Nebraska, USA.

Johnson, L. A., and L. A. Foote. 1997. Vertebrate herbivory in managed coastal wetlands-a manipulative experiment. Aquatic Botany 59:17-32.

Johnson, L. A., and L. A. Foote. 2005. Effects of managed impoundments and herbivory on wetland plant production and stand structure. Wetlands 25:38-50.

Just C., and J. Lartigue. 2004. Patterns of herbivory and decomposition in aquatic and terrestrial ecosystems. Ecological Monographs 74:237-259.

Kerbes, R. H., P. M. Kotanen, and R. L. Jefferies. 1990. Destruction of wetland habitats by Lesser Snow Geese: A keystone species on the west coast of Hudson Bay. Journal of Applied Ecology 27:242-258.

LaMontagne J. M., L. J. Jackson, and R. M. R. Barclay. 2003. Compensatory growth responses of Potamogeton pectinatus to foraging by migrating Trumpeter Swans in spring stop over areas. Aquatic Botany 76:235-244.

Lippson, A. J. 1973. The Chesapeake Bay in Maryland: an atlas of natural resources, Johns Hopkins University Press, Baltimore, Maryland, USA.

Lodge, D. M. 1991. Herbivory on freshwater macrophytes. Aquatic Botany 41:95-224. 
Lodge, D. M., J. W. Barko, D. Strayer, J. Melack, G., G. Mittlebach, R. W. Howarth, B. Menge, and J. E. Titus. 1988. Spatial heterogeneity and habitat interactions in Lake Communities. Pages 181-208 in S. R. Carpenter, editor. Complex interactions in Lake Communities, Springer, Berlin, Germany.

Maryland Department of Natural Resources. 2005a. Recent water and habitat conditions in Maryland's Chesapeake Bay and Coastal Bays. 〈http://mddnr.chesapeakebay.net/eyesonthebay/index.cfm〉

Maryland Department of Natural Resources. 2005b. Bay grasses identification key. Maryland Department of Natural Resources, Annapolis, Maryland, USA. $\langle$ http://www.dnr.state.md.us/bay/sav/key/〉

Meyers, E., R. Fischman, and A. Marsh. 1995. Maryland Chesapeake Bay critical areas program: wetland protection and future growth. Page 189-201 in D. R. Porter and D. A. Salvesen, editors. Collaborative planning for wetlands and wildlifeissues and examples. Island Press, Washington D.C., USA.

Mitchell, S. F., and M. R. Perrow. 1998. Interaction between grazing birds and macrophytes. Pages 175-196 in E. Jeppesen, M. Sondergaard, and K. Christoffersen, editors. The structuring role of submerged macrophytes in lakes. Springer, Berlin, Germany.

Mitchell, S. F., and R. T. Wass. 1996. Grazing by Black Swans (Cygnus atratus Latham), physical factors, and the growth and loss of aquatic vegetation in a shallow lake. Aquatic Botany 55:205-215.

Mountford, K. 2004. Mute Swan testimony: some dialog about swans and humankind through history. Pages 2-6 in M. C. Perry, editor. Mute Swans and their Chesapeake Bay Habitats: Proceedings of a Symposium: U.S. Geological Survey, 
Biological Resources Discipline Information and Technology Report USGS/BRD/ITR- 2004-0005.

Naylor, M. 2004. Potential impacts of Mute Swans to SAV in Chesapeake Bay. Pages 36-37 in M. C. Perry, editor. Mute Swans and their Chesapeake Bay Habitats: Proceedings of a Symposium: U.S. Geological Survey, Biological Resources Discipline Information and Technology Report USGS/BRD/ITR- 2004-0005.

Nolet, B. A. 2004. Overcompensation and grazing optimization in a swan-pondweed system? Freshwater Biology 49:1391-1399.

Ogilvei, M. A. 1978. Wild Geese. Buteo Books, Vermillion, South Dakota, USA.

Orth, R. J., D. J. Wilcox, L. S. Negey, J. R. Whiting, and J. R. Fishman. 2001. 2001 distribution of submerged aquatic vegetation in the Chesapeake Bay and Coastal Bay, Glouchester, Virginia, Virginia Institute of Marine Science, Special Scientific Report No. 142.

Orth, R. J., D. J. Wilcox, L. S. Negey, J. R. Whiting, and J. R. Fishman. 2003. 2003 distribution of submerged aquatic vegetation in the Chesapeake Bay and Coastal Bay, Glouchester, Virginia, Virginia Institute of Marine Science, Special Scientific Report No. 144.

Owen, M., and C. J. Cadbury. 1975. The ecology and mortality of Mute Swans at the Ouses Washes, England. Wildfowl 25:31-42.

Owen, M., and J. Kear. 1972. Food and feeding habits. Pages 58-77 in P. Scott, editor. The swans. Houghton Mifflin Company, Boston, Massachusetts, USA.

Perrow, M. R., J. H. Schutten, J. R. Howes, T. Holzer, F. J. Madgwick, and A. J. D. Jowitt. 1997. Interaction between Coot (Fulica atra) and submerged 
macrophytes: the role of birds in the restoration process. Hydrobiologia 342/343:241-255.

Person, B. T., M. P. Herzog, and R. W. Ruess. 2003. Feedback dynamics of grazing lawns: coupling vegetation change with animal growth. Oecologia 135:583-592.

Perry, M. C., P. C. Osenton, and E. J. R. Lohnes. 2004. Food habits of Mute Swans in Chesapeake Bay. Pages 31-36 in M. C. Perry, editor. Mute Swans and their Chesapeake Bay Habitats: Proceedings of a Symposium: U.S. Geological Survey, Biological Resources Discipline Information and Technology Report USGS/BRD/ITR- 2004-0005.

Pimentel, D. L., Z. Lori, and M. D. Rodolfo. 2000. Environmental and economic costs of nonindigenous species in the United States. BioScience 50:53-64.

Qvarnemark, L. M., and S. P. Sheldon. 2004. Moose grazing decreases aquatic plant diversity. Journal of Freshwater Biology 19:407-410.

Santamaria, L., and M. A. Rodriguez-gironés. 2002. Hiding from swans: optimal burial depth of sago pondweed tubers foraged by Bewick's Swans. Journal of Ecology 90:303-315.

SAS Institute, Inc. 2001. SAS/STAT software. Cary, North Carolina, USA.

Scott, P. 2004. Review of the status of Mute Swans on the Canadian side of the Lower Great Lakes. Pages 23-27 in M. C. Perry, editor. Mute Swans and their Chesapeake Bay Habitats: Proceedings of a Symposium: U.S. Geological Survey, Biological Resources Discipline Information and Technology Report USGS/BRD/ITR-2004-0005.

Sherfy, M. H., and R. L. Kirkpatrik. 2003. Invertebrate response to Snow Goose herbivory on moist-soil vegetation. Wetlands 23:236-249. 
Smith, T. J., and W. E. Odum. 1981. The effect of grazing by Snow Geese on coastal salt marshes. Ecology 62:98-106.

Stewart, R. E. 1962. Waterfowl populations in the upper Chesapeake Region. U.S. Fish and Wildlife Service, Special Scientific Report - Wildlife No 65. U.S. Department of the Interior, Washington D.C., USA.

Temple, S. A. 1992. Exotic birds: a growing problem with no easy solution. Auk 109:395-397.

Thayer, G. W., K. A. Bjorndal, J. C. Ogden, S. L. Williams, and J. C. Zieman. 1984. Role of larger herbivores in seagrass communities. Estuary 7:351-376.

Therres, G., and D. Brinker. 2004. Mute Swan interaction with other birds in Chesapeake Bay. Pages 43-46 in M. C. Perry, editor. Mute Swans and their Chesapeake Bay Habitats: Proceedings of a Symposium: U.S. Geological Survey, Biological Resources Discipline Information and Technology Report USGS/BRD/ITR- 2004-0005.

Trlica, M. J., and L. R. Rittenhouse. 1993. Grazing and plant performance. Ecological Applications 3:21-23

Van Donk, E. 1998. Switches between clear and turbid water states in biomanipulated lake (1986-1996): the role of herbivory on macrophytes. Pages 290-297 in E. Jeppensen, M. Sondergaard, and K. Christoffersen, editors. Lake Veluwe, a macrophyte-dominated system eutrophication stress. Kluwer Academic Publishers, Dordrecht, The Netherlands.

Vitousek, P. M., C. M. D,’ Antonio, L. L. Loope, and R. Westbrooks. 1996. Biological invasions as global environmental change. American Scientist 84:468-478. 
Willey, C. H., and B. F. Halla. 1972. Mute swans of Rhode Island. Wakefield, Rhode Island. Rhode Island Department of Natural Resources, Division of Fish and Wildlife, Wildlife Pamphlet, no. 8. 
TABLE 1. The Daubenmire cover classes used to assess extent of substrate covered by SAV in the Chesapeake Bay, 2003 and 2004.

\begin{tabular}{lcc}
\hline Cover class & Range of cover (\%) & Midpoint of class (\%) \\
\hline 1 & $>0-5$ & 2.5 \\
2 & $6-25$ & 15.0 \\
3 & $26-50$ & 37.5 \\
4 & $51-75$ & 62.5 \\
5 & $76-95$ & 85.0 \\
6 & $96-100$ & 97.5 \\
\hline
\end{tabular}


TABLE 2. Mean ( $\pm 1 \mathrm{SE})$ values of submerged aquatic vegetation characteristics in the sampling plots at study sites $(n=18)$ in Chesapeake Bay, Maryland at the end of the study (May 2003 - August 2004).

\begin{tabular}{|c|c|c|c|c|c|c|}
\hline \multirow{3}{*}{ Parameter } & \multicolumn{6}{|c|}{ Sampling Plot ${ }^{\mathrm{a}}$} \\
\hline & \multicolumn{2}{|c|}{ 2-year exclosure } & \multicolumn{2}{|c|}{ 1- year exclosure } & \multicolumn{2}{|c|}{ 2- year open (control) } \\
\hline & $\bar{x}$ & SE & $\bar{x}$ & SE & $\bar{x}$ & $\mathrm{SE}$ \\
\hline Percent Cover & $43.3 \mathrm{a}$ & 8.1 & $25.6 \mathrm{~b}$ & 6.5 & $9.2 \mathrm{c}$ & 2.5 \\
\hline Density (shoots $/ \mathrm{m}^{2}$ ) & $254.9 \mathrm{a}$ & 47.8 & $140.1 b$ & 33.3 & $59.7 \mathrm{c}$ & 21.5 \\
\hline Canopy height (cm) & $10.8 \mathrm{a}$ & 0.5 & $9.5 b$ & 0.6 & $6.5 \mathrm{c}$ & 0.5 \\
\hline
\end{tabular}

${ }^{\mathrm{a}}$ The same letters in a row indicate no significant difference in means $(P>0.05)$. 
TABLE 3. Water depth (m) classes, Mute Swan social status categories, and percent cover reduction of submerged aquatic vegetation (SAV) due to herbivory at study sites $(n=18)$, Chesapeake Bay, Maryland, May 2003-August 2004.

\begin{tabular}{|c|c|c|c|c|}
\hline \multirow[t]{2}{*}{ Study Site } & \multirow{2}{*}{$\begin{array}{l}\text { Water-depth } \\
\text { class }^{\mathrm{a}}\end{array}$} & \multirow[t]{2}{*}{ Social status } & \multicolumn{2}{|c|}{ SAV reduction ${ }^{b}$} \\
\hline & & & $\%$ & Intensity \\
\hline Audubon Sanctuary & $0.95(\mathrm{M})$ & Pair & 55 & Moderate \\
\hline Bay Shore Road & $0.75(\mathrm{~S})$ & Flock & 100 & Substantial \\
\hline Brannock Bay & $0.79(\mathrm{M})$ & Pair & 63 & Moderate \\
\hline Claiborn Harbor & $0.75(\mathrm{~S})$ & Flock & 89 & Substantial \\
\hline Covey Point Farm & $0.69(\mathrm{~S})$ & Flock & 93 & Substantial \\
\hline Church Neck Road & $0.91(\mathrm{M})$ & Pair & 36 & Low \\
\hline Haven on Bay & $0.59(\mathrm{~S})$ & Flock & 83 & Substantial \\
\hline Hill Point Cove & $1.00(\mathrm{D})$ & Flock & 77 & Substantial \\
\hline Hooper Island Road & $1.00(\mathrm{D})$ & Pair & 90 & Substantial \\
\hline Middle Point Road & $0.64(\mathrm{~S})$ & Flock & 89 & Substantial \\
\hline Osprey Point & $0.95(\mathrm{M})$ & Flock & 93 & Substantial \\
\hline Partridge Lane & $1.10(\mathrm{D})$ & Flock & 81 & Substantial \\
\hline Punch Pont Road & $1.02(\mathrm{D})$ & Pair & 93 & Substantial \\
\hline Ragged Point & 1.07(D) & Flock & 91 & Substantial \\
\hline Tar Bay & $0.50(\mathrm{~S})$ & Flock & 75 & Moderate \\
\hline
\end{tabular}




$\begin{array}{lllll}\text { Todd's Point Road } & 0.76(\mathrm{M}) & \text { Pair } & 32 & \text { Low } \\ \text { Twins Point Road } & 0.77(\mathrm{M}) & \text { Pair } & 75 & \text { Moderate } \\ \text { Wades Point Road } & 0.54(\mathrm{~S}) & \text { Flock } & 100 & \text { Substantial }\end{array}$

${ }^{\mathrm{a}} \mathrm{D}$ : Deep water sites (i.e., depth $\left.\geq 1 \mathrm{~m}\right)$, M: Moderate-depth sites $(0.76 \mathrm{~m}$ to $0.99 \mathrm{~m})$, S: Shallow water sites $(0.5 \mathrm{~m}$ to $0.75 \mathrm{~m})$.

${ }^{\mathrm{b}}$ Substantial: mean $\%$ cover in 2-year exclosures is $>75 \%$ higher than that in 2 year open plots, Moderate: mean \% cover in 2-year exclosures is $51-75 \%$ higher than that in 2 year open plots, Low: mean \% cover in 2 -year exclosures is $26-50 \%$ higher than that in controls. 
TABLE 4. Summary of waterbird species sharing study sites $(n=18)$ with Mute Swans during exclosure study on the Chesapeake Bay, Maryland, May 2003 - August 2004.

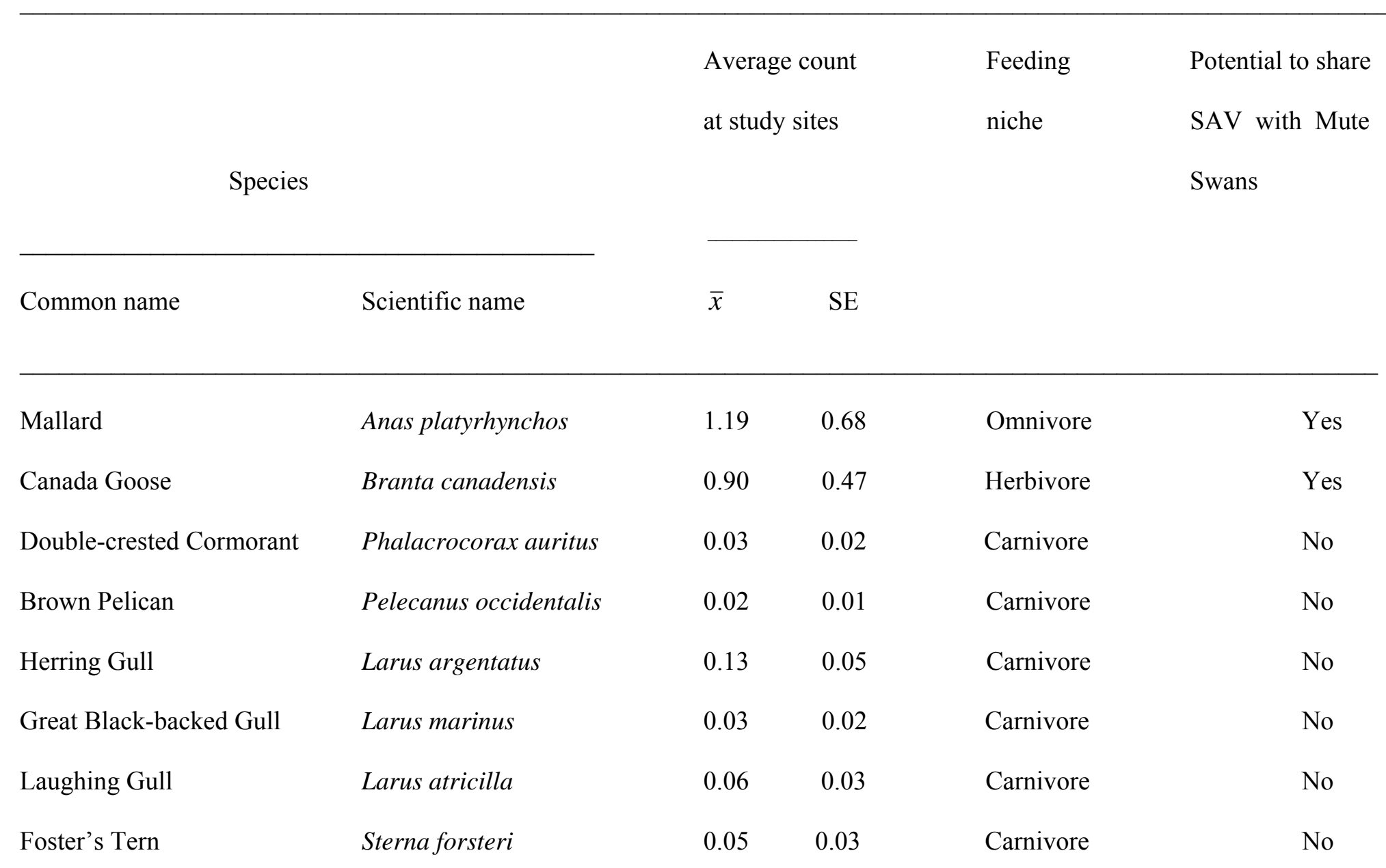




\begin{tabular}{|c|c|c|c|c|c|}
\hline Common Tern & Sterna hirundo & 0.14 & 0.06 & Carnivore & No \\
\hline Least Tern & Sterna antillarum & 0.04 & 0.02 & Carnivore & No \\
\hline Great Blue Heron & Ardea herodias & 0.16 & 0.04 & Carnivore & No \\
\hline Great Egret & Ardea alba & 0.05 & 0.01 & Carnivore & No \\
\hline Snowy Egret & Egretta thula & 0.08 & 0.03 & Carnivore & No \\
\hline Green Heron & Butorides virescens & 0.05 & 0.02 & Carnivore & No \\
\hline Willet & Catoptrophorus semipalmatus & 0.02 & 0.001 & Carnivore & No \\
\hline
\end{tabular}




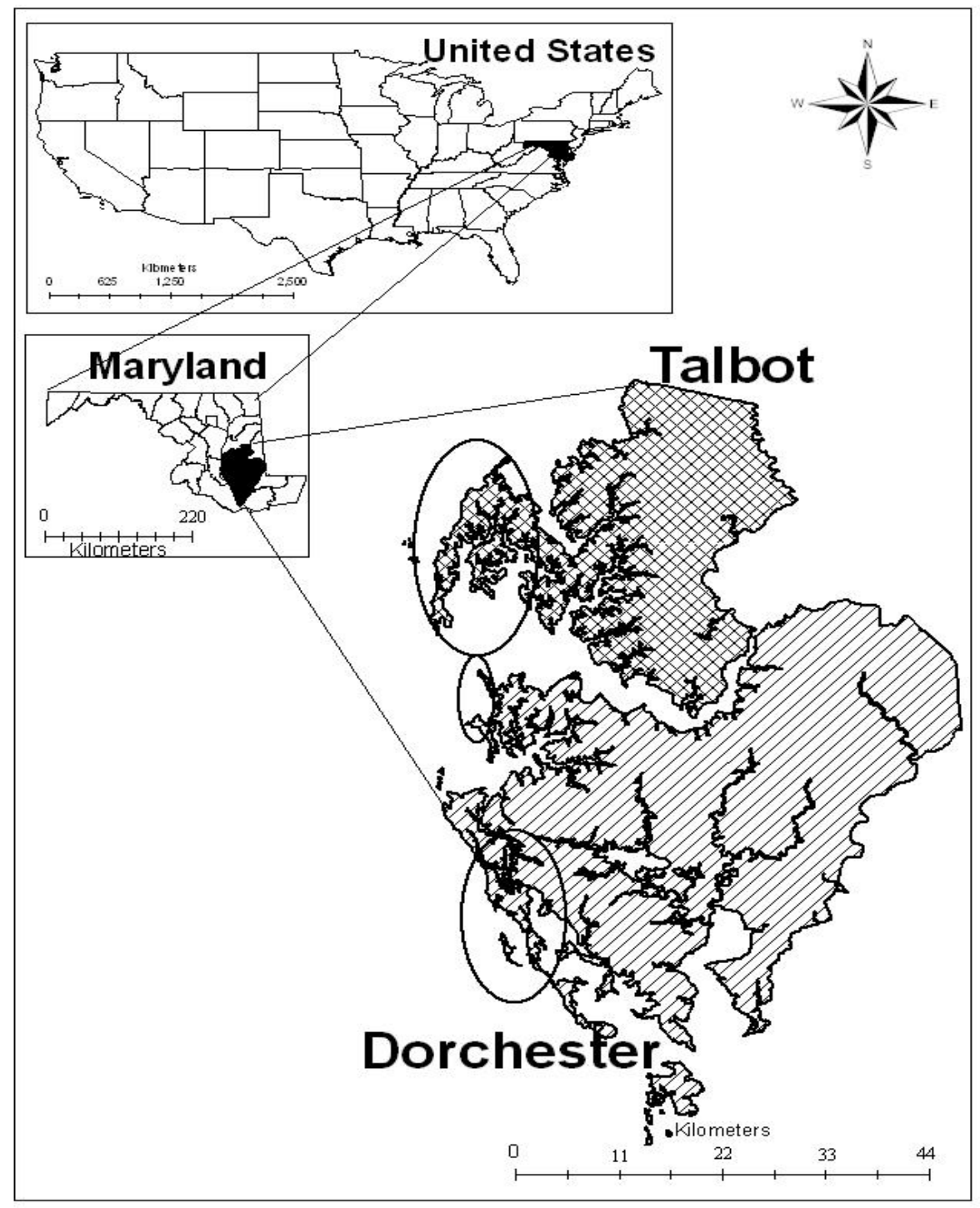

Fig. 1. Portions of Talbot and Dorchester Counties, Maryland (marked with ovals) on the eastern shore of Chesapeake Bay wherein the sites $(n=18)$ for the submerged aquatic vegetation exclosures were located, 2003 and 2004. 


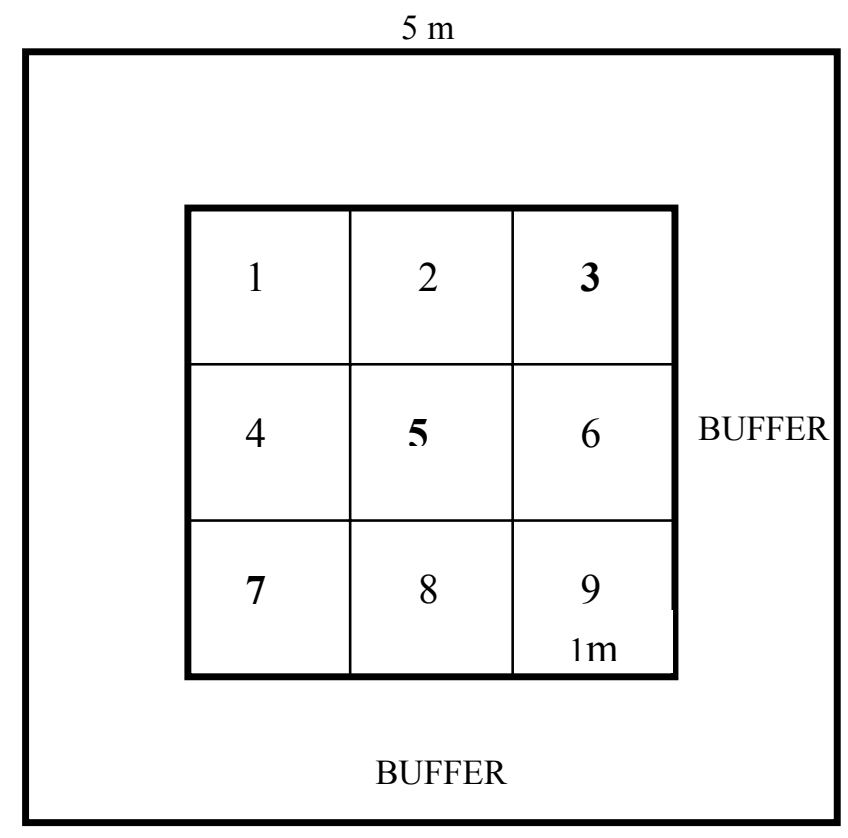

FIG. 2. Lay out of sampling sub-plots ( $1 \times 1 \mathrm{~m})$ in a sampling plot $(5 \times 5 \mathrm{~m})$ with core sub-plots marked with numbers ranging from 1 through 9 and diagonally located sub-plots $(3,5,7)$ used for submerged aquatic vegetation measurement marked in bold fonts, 2003 and 2004. 


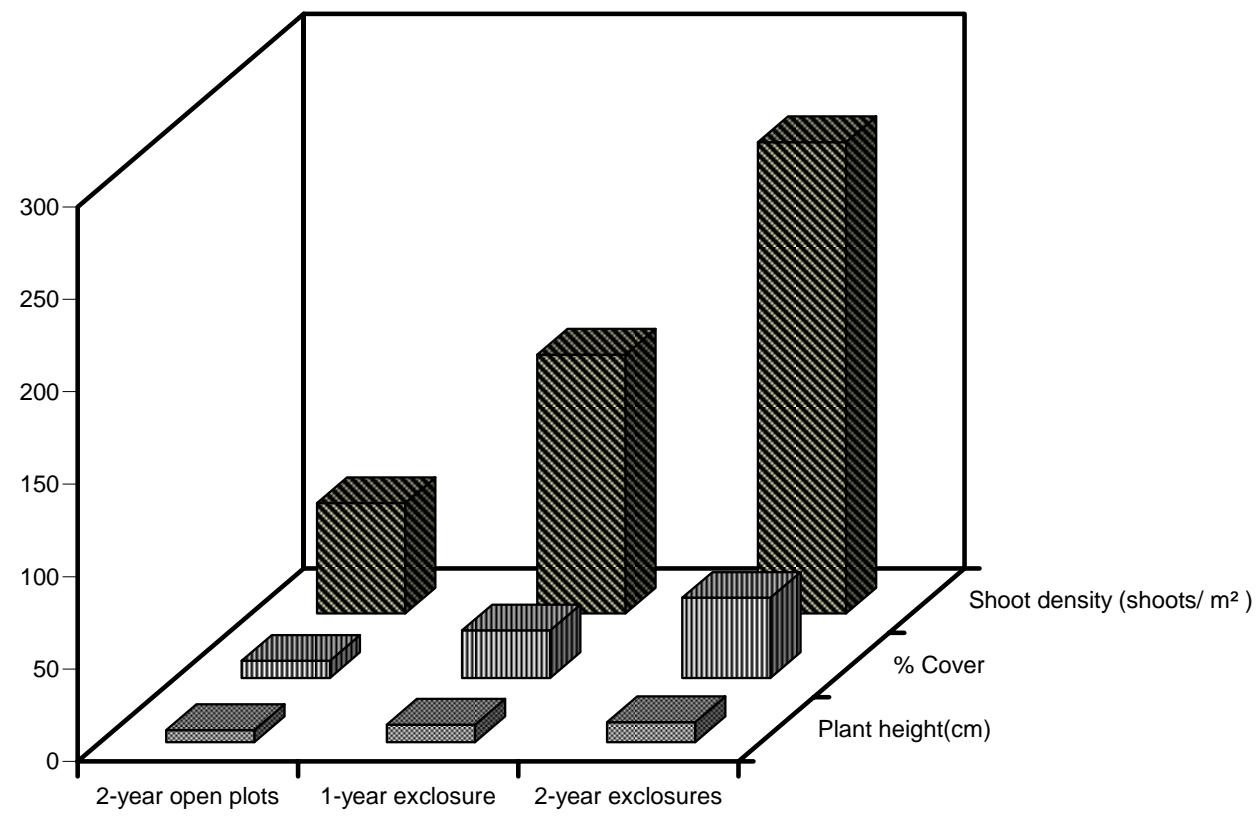

FIG. 3. Mean percent cover, mean shoot density, and mean canopy height of submerged aquatic vegetation in the control and treatment plots in the Chesapeake Bay, Maryland, 2003 and 2004. 
a. Percent cover
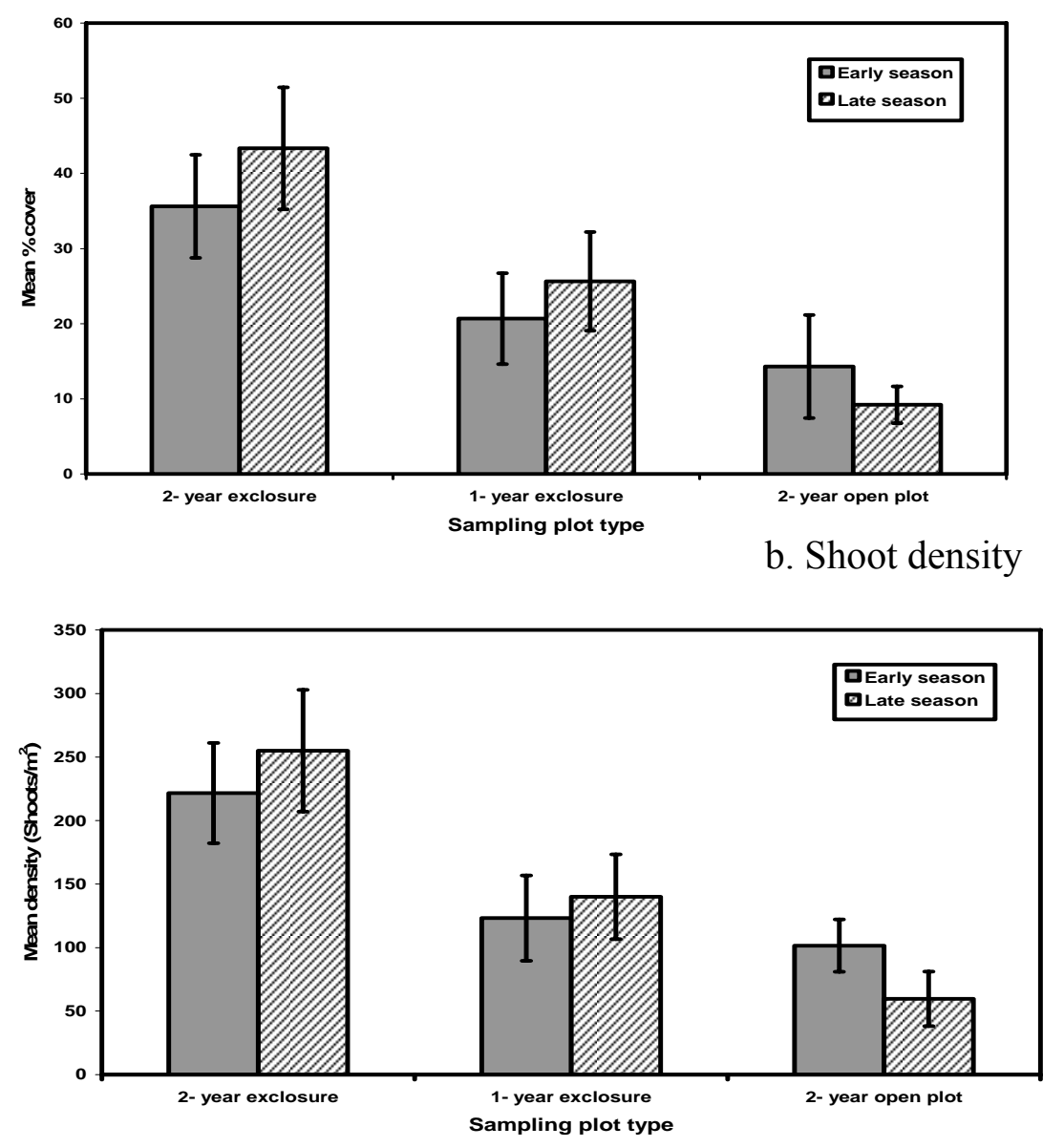

c. Height

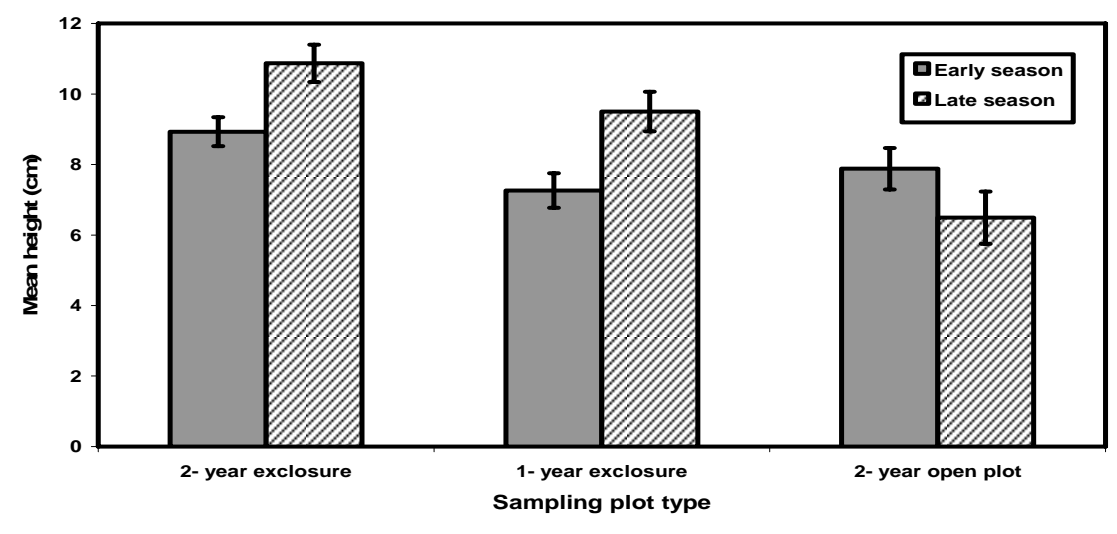

FIG. 4. Submerged aquatic vegetation percent cover (a), shoot density (b), and height (c) in the sampling plots from early to late growing season (2004) in the Chesapeake Bay, Maryland. 


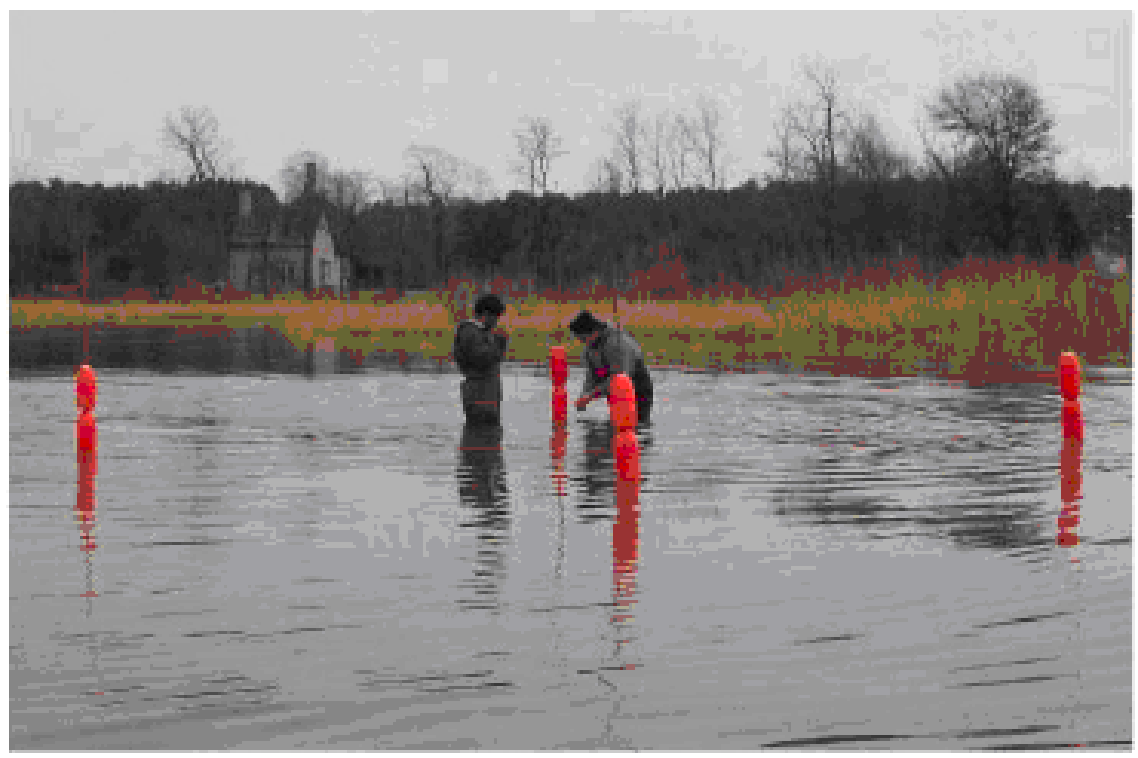

FIG. 5. Mute Swan exclosure (under construction) in the Chesapeake Bay, Maryland.

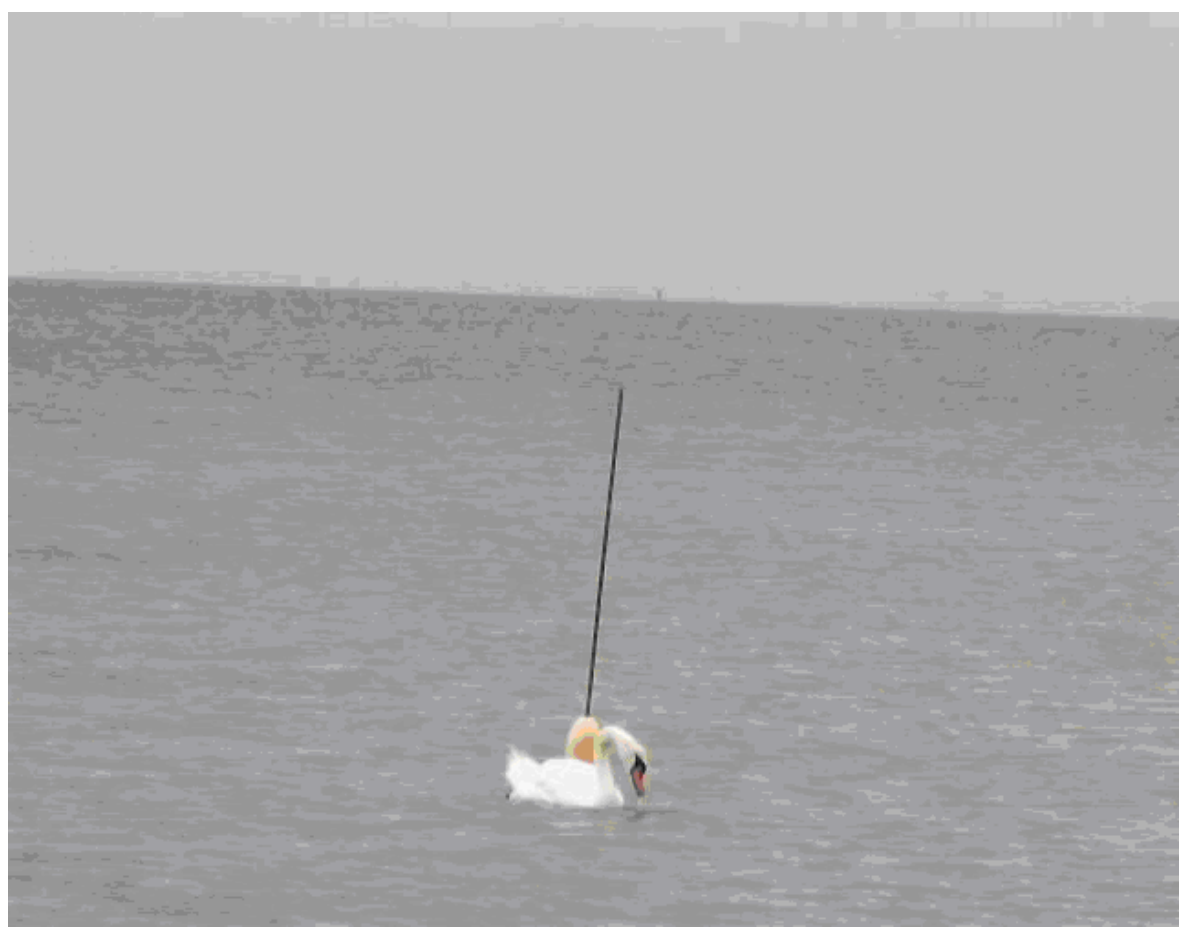

FIG. 6. Open plot (marked by a pole) at a study site in the Chesapeake Bay, Maryland. 


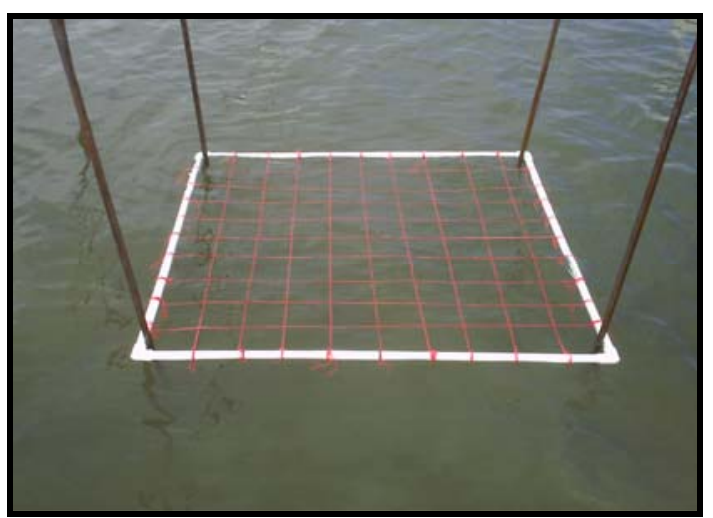

a) Frame for shoot density measurement

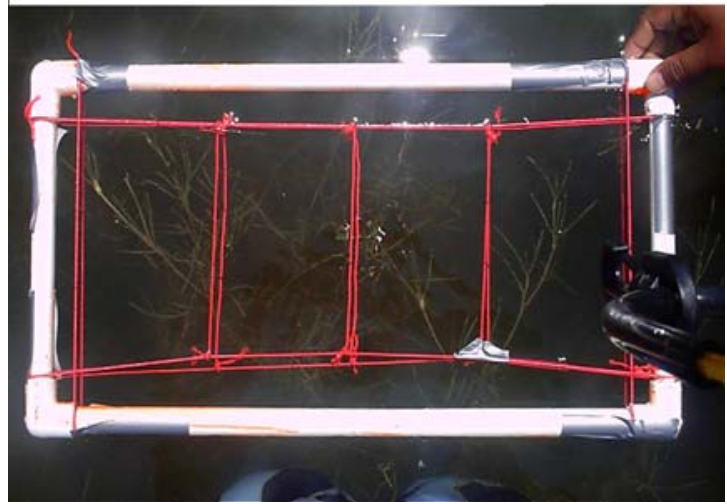

b) Daubenmire frame to measure $\%$ cover

FIG. 7. Frames used for measuring submerged aquatic vegetation (SAV) in the Chesapeake Bay, Maryland.
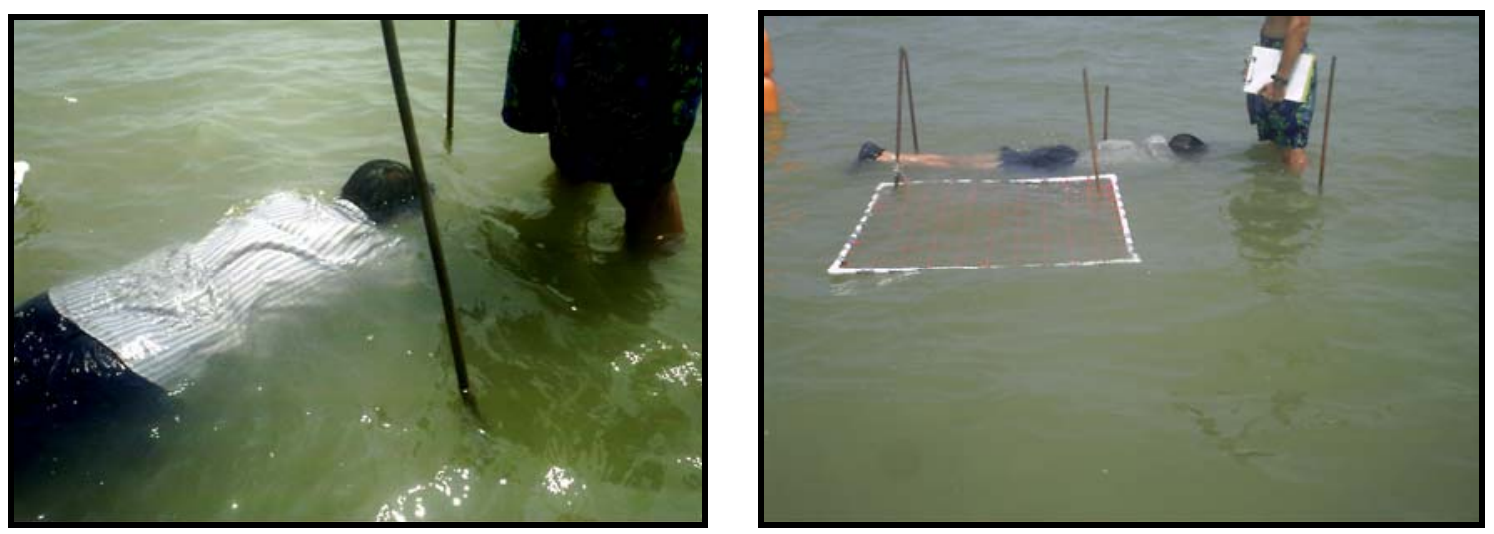

FIG. 8. Underwater measurement of submerged aquatic vegetation (SAV) at a study site in the Chesapeake Bay, Maryland. 


\title{
CHAPTER IV
}

\section{PREDICTIVE MODELING FOR SUBMERGED AQUATIC VEGETATION (SAV) DECLINE DUE TO MUTE SWANS IN THE CHESAPEAKE BAY}

\author{
KETAN S. TATU ${ }^{1}$, JAMES T. ANDERSON ${ }^{1}$, AND LARRY J. HINDMAN ${ }^{2}$ \\ ${ }^{1}$ Division of Forestry, West Virginia University, P.O. Box 6125, Morgantown, \\ WV 26506, USA \\ ${ }^{2}$ Maryland Department of Natural Resources, 828B Airpax Road, Wildlife and \\ Heritage Service, Cambridge, MD 21613, USA
}




\begin{abstract}
Mute Swans (Cygnus olor) contribute to a reduction in Submerged Aquatic Vegetation (SAV) in the Chesapeake Bay, USA owing to their high preference for SAV as a food resource, increasing population, year-round inhabitation of the Bay, and substantial appetite. However, quantitative data on SAV decline due to Mute Swan herbivory along with other potential factors have not been hitherto generated for the entire Bay. Based on biology and current knowledge of SAV and Mute Swans in the Bay, we developed a suite of 15 a priori statistical models that could potentially predict SAV cover decline in the Bay. Each model had Mute Swan population and/or one or more other potential environmental factors as independent variables (predictors) and SAV percent cover decline as the dependent variable. We generated data by measuring SAV percent cover reduction, water depth, extent of light penetration, salinity, and number of Mute Swan at 18 sites. Using these localized data, we further ranked all the candidate models through Akaike's Information Criterion (AICc) model selection. Based on the smallest value of AICc, we selected the predictive model including 4 predictors (i.e., water depth, extent of light penetration, salinity, and number of Mute Swans) as the most parsimonious model. In addition, we also developed Geographical Information System (GIS) based spatial models. The models revealed that $43 \%$ percent of the total SAV area has beds of widgeon grass (Ruppia maritima) or eelgrass (Zostera marina) (or both) with $40-100 \%$ cover and such area potentially faces the highest threat from Mute Swan herbivory. One percent of the total SAV area in the Bay needs urgent protection from Mute Swan herbivory. Large flocks of Mute Swans $(n>50)$ were primarily located in areas that had beds of widgeon grass and eelgrass with higher cover values and such
\end{abstract}


areas occupy a considerable proportion of total SAV area in the Bay. Statistical modeling suggested that although Mute Swan herbivory is not the most important factor influencing SAV decline in the Bay, it certainly contributes to SAV decline. Therefore, Mute Swan impact should be incorporated into a larger framework of SAV protection in Chesapeake Bay.

Key words: Akaike's Information Criterion (AICc), Chesapeake Bay; Cygnus olor; eelgrass, exclosure study; exotic; GIS, invasions; Mute Swan; Ruppia maritima; Submerged Aquatic Vegetation; SAV, widgeon grass.

A part of this chapter is written in the style of the Proceedings of the Trumpeter Swan Society. 


\section{INTRODUCTION}

Mute Swans (Cygnus olor) are native to Eurasia and were introduced into North America in the late 1800s and early 1900s (Bellrose 1980, Ciaranca et al. 1997). Since the mid-to-late portion of the twentieth century, Mute Swan populations have been rapidly expanding particularly along the Atlantic Coast (Scott 2004). The portion of the Chesapeake Bay located in Maryland, has greatly contributed to the expansion as the population increased at an annual rate of 23\% between $1986-92$ and 10\% between 1993 99 resulting in the population as high as 4,000 individuals (Hindman and Harvey 2004). The phenomenal population growth of Mute Swans is harmful to Submerged Aquatic Vegetation (SAV) in the Bay as it is the mainstay of their diet (Bellrose 1980). There is anecdotal evidence to conclude that Mute Swans impact SAV in the Bay (Hindman and Harvey 2004, Perry et al. 2004).

Submerged Aquatic Vegetation in the Bay plays a vital role in providing habitat and food to numerous native organisms and performs several other important ecological functions (Maryland Department of Natural Resources [DNR] 2001). It is a stressed resource since the 1960s due to several man-induced and natural factors (Hurley 1990, Naylor 2004). The increased population of Mute Swans has put additional pressure on SAV (Hindman and Harvey 2004). Although Mute Swans are believed to contribute to the SAV decline and hamper SAV restoration activities in the Chesapeake Bay, quantitative data on reduction of SAV by Mute Swans is limited (Hindman and Harvey 2004). Numerous other factors affect SAV growth in the Bay including weather events (e.g., storm), natural population cycles, animal grazing and foraging, industrial pollutants, agricultural herbicides and general decline in water quality due to increased loading of 
nutrients and sediment from the surrounding watersheds (Hurley 1990). The relative importance of the impact of Mute Swan herbivory compared to abiotic factors on SAV decline and identification of potential SAV areas being threatened from Mute Swan herbivory is unknown. Therefore, we carried out this study with the primary objectives to: 1) develop the best approximating parsimonious predictive model for SAV cover decline in the Bay using an information-theoretic approach, and 2) identify, locate, and depict potentially threatened SAV areas due to Mute Swan herbivory using the Geographic Information System (GIS).

\section{STUDY AREA}

We conducted statistical and spatial modeling for the Chesapeake Bay, USA (Figure 1). We collected localized data on the eastern shore of Chesapeake Bay, Maryland, USA (Figure 2). The Bay is formed by over 150 rivers and streams and tidal waters of the Atlantic Ocean and it is one of the primary waterfowl wintering areas in the Atlantic Flyway (Hindman and Stotts 1989, Meyers et al. 1995). The Chesapeake Bay traditionally has played a vital role in providing habitat to wintering native waterfowl, but now it is inhabited by thousands of resident exotic Mute Swans since the 1990s. Chesapeake Bay is a 8-48 km wide and $288 \mathrm{~km}$ long shallow estuary, that lies in a northsouth direction, roughly parallel to the Atlantic seacoast.

For the localized data collection, we covered 18 sites in the mid-Bay ( 8 in Talbot County and 10 in Dorchester County of Maryland). The sites were located between $38^{\circ}$ $25^{\prime} 00^{\prime \prime} \mathrm{N}$ and $38^{\circ} 52^{\prime} 30^{\prime \prime} \mathrm{N}$ latitudes and $76^{\circ} 07^{\prime} 30^{\prime \prime} \mathrm{W}$ and $76^{\circ} 22^{\prime} 30^{\prime \prime} \mathrm{W}$ longitudes. SAV species at our study sites were widgeon grass (Ruppia maritima) and horned 
pondweed (Zannichellia palustris), but widgeon grass which is tolerant of a wide range of salinities was wide-spread and most dominant (Chapter 3). The population of Mute Swans was highest (total 3,286 individuals) along the eastern shore of the Chesapeake Bay (Hindman and Harvey 2004). Specifically, Dorchester (1,638 swans) and Talbot (1,023 swans) Counties of Maryland in the mid-Bay area supported the largest number of Mute Swans (Maryland DNR 2002, Hindman and Harvey 2004).

\section{METHODS}

\section{Localized Data Collection}

We established 18 study sites with SAV beds and Mute Swans (pairs/flocks) in Talbot and Dorchester Counties, Maryland in 2003 and 2004. To assess the SAV cover decline under the influence of Mute Swan foraging at each site, we established multiple sets of treatment (exclosures) and control (open) plots in the SAV beds at each site before the on-set of the SAV growing season. Each site had 3 sets of $5 \times 5 \mathrm{~m}$ control and treatment sampling plots. All sampling plots in a set were established in an SAV bed with uniform density level. Using a Daubenmire frame, we measured percent cover of SAV in all the sampling plots at each of the 18 sites at the end of the second consecutive season of SAV growth after the establishment of the sampling plots. Based on these measurements, we determined the difference in percent cover of SAV between 54 2-year treatment and 54 2-year control plots for each of the 18 sites. The percentage difference represented SAV cover decline for each site. Detailed information on exclosures and study design can be found in Chapter 3 . 
We also measured environmental factors for each site. They included water depth (WD), extent of light penetration (LP), and salinity (S). Water depth was measured to the nearest $1 \mathrm{~cm}$ on a permanently marked pole, extent of light penetration (i.e., the ratio of Secchi depth to water depth) was measured using a Secchi disk, and salinity was measured using a YSI salinity meter. Moreover, we also estimated average Mute Swan population (SP) for each site by counting the swans fortnightly.

\section{Statistical Model Development}

We considered a basic a priori model in which the predictors (covariates) for SAV cover decline $(\mathrm{Y})$ were selected based on our current knowledge regarding SAV and Mute Swans in the Bay. Its structure can simply be expressed as:

$$
\mathrm{Y}=(\mathrm{WD}) \pm(\mathrm{LP}) \pm \mathrm{S} \pm \mathrm{SP} .
$$

We further translated it into a statistical model in the form of a linear regression model as given below:

$$
\mathrm{Y}=\beta_{0}-\beta_{1}(\mathrm{WD})-\beta_{2}(\mathrm{LP})+\beta_{3}(\mathrm{~S})+\beta_{4}(\mathrm{SP}) \text {, where }
$$

$\mathrm{Y}=\mathrm{SAV}$ cover decline at a site in the Bay, $\beta_{0}=$ intercept, $\beta_{1}(\mathrm{WD})=$ slope on water

depth, $\beta_{2}(\mathrm{LP})=$ slope on extent of light penetration, $\beta_{3}(\mathrm{~S})=$ slope on salinity, and $\beta_{4}(\mathrm{SP})$ $=$ slope on average population of Mute Swans.

In developing the model we hypothesized that SAV percent cover decline (Y) had a negative linear relationship with water depth (WD) and extent of light penetration (LP), but had a positive linear relationship with salinity (S) and average Mute Swan population (SP). Based on the basic model, we further developed 14 other a priori candidate models by considering all possible biologically meaningful associations of the covariates (i.e., 
WD, LP, S, and SP) used in the basic model. As a result, we had a suite of 15 a priori candidate models, each having an unique structure (Table 1). In our a priori models, we did not include any interactions of covariates as there is typically only one model without interactions but an infinite number of models with interactions because the interaction can be characterized by any function of the covariates (Mangel et al. 2001). We used an information theoretic approach to select the relatively best predictive model among the general linear models for SAV cover decline. This method allows model uncertainty to be included in model evaluation and the derivation of parameter estimates (Burnham and Anderson 1998). The best approximating and competing models were identified using Akaike's Information Criterion corrected for small sample size $\left(\mathrm{AIC}_{\mathrm{c}}\right)$ in Proc Mixed (SAS 2001) which determines AIC values based on likelihood. Model comparisons were made with $\triangle \mathrm{AIC}$, which is the difference between the $\mathrm{AIC}_{\mathrm{c}}$ for each individual model and the lowest observed $\mathrm{AIC}_{\mathrm{c}}$ value (Burnham and Anderson 1998). Models with $\mathrm{AAIC}_{\mathrm{c}}$ $\leq 2$ have substantial support from the data (Burnham and Anderson 1998). To evaluate support for model parameters, we summed $\mathrm{AIC}_{\mathrm{c}}$ model weights across all models. The $\mathrm{AIC}_{\mathrm{c}}$ weight of a model signifies the relative likelihood that the specific model is the best of all the models in a suite. It was premised that the parameters with good support will have high summed $\mathrm{AIC}_{\mathrm{c}}$ model weight values (near 1) due to that parameter's inclusion in most of the better models (Burnham and Anderson 1998).

\section{Spatial Model Development}

A spatial model can be defined as one that has either one or more variables that are a function of space or can be related to other space-dependent data (Sklar and 
Hunsaker 2001). Spatial models are developed using computer based GIS by manipulating and analyzing spatially-distributed data. For developing such models, the GIS can be used to conduct complex analyses of geographically referenced data, with emphasis on spatial and non-spatial attributes. Geographic Information Systems determine spatial coincidence of physical and biological features, and determine spatial characteristics such as proximity, contiguity, and patch size and shape (Johnson 1990). Using GIS, the potential distribution of any organism can be spatially modeled precisely with geographic coordinates (Stine and Hunsaker 2001), which is important from a management point of view.

We used ArcMap (version 9.1) in ArcGIS 9.0 for identifying, locating, and depicting potential SAV areas in the Bay having a low to high threat of destruction due to Mute Swan herbivory. We obtained GIS data layers from 3 different sources (Table 2). The shape file pertaining to the SAV beds in the Bay was downloaded from the link provided by Virginia Institute of Marine Sciences (VIMS) (Davis Wilcox, VIMS, personal communication) (Fig. 3).

We premised that only those SAV species that are most prevalent in the diet of Mute Swans in the Bay (i.e., widgeon grass [Ruppia maritime] and eelgrass [Zostera marina]) would be the most heavily consumed species compared to other types of SAV (Hindman and Harvey 2004, Perry et al. 2004) and the beds endowed with such species were classified as beds with most consumed species (BMOSCS). Apart from BMOCS, we also determined 2 other types of SAV beds. Beds endowed with widgeon grass or eelgrass in combination with other SAV species that are not prevalent in the diet of Mute Swans (or not heavily consumed by the swans) were classified as beds with moderately 
consumed species (BMODCS) and SAV beds with species that are least prevalent in Mute Swans' diet (i.e., least consumed by Mute Swans) were classified as the beds with least consumed species of SAV (BLCS).

Abundance of SAV in a locality also can influence intensity of SAV bed use due to Mute Swan foraging, because swans tend to use the beds with moderate and high SAV density classes $(n=4$, i.e., very sparse $[0-10 \%$ coverage], sparse [ $>10-40 \%$ coverage], moderate $[>40-70 \%$ coverage], and high $[>70-100 \%$ coverage $]$ ) (Orth et al. 2003, Sousa 2005). From locations for 110 Mute Swans with vhf radiotransmitters or neck collars, $<1 \%(\mathrm{n}=505$ locations $)$, were in very sparse SAV beds, $7 \%$ were in sparse SAV beds, $56 \%$ were in moderate beds, and $37 \%$ were in the SAV beds with high coverage values (Sousa 2005). We considered 2 levels of density (i.e., level-1 and level-2) for each of the 3 types of SAV beds (i.e., BMOSCS, BMODCS, and BLCS) (Figs. 5-7). Level-1 beds had $>40-100 \%$ and are likely to be visited by Mute Swans more frequently. Level-2 beds had lower cover (i.e., 0-40\%) that would be explored by Mute Swans less frequently.

Besides, SAV data, we also added bathymetry data for the Chesapeake Bay to the existing maps. The bathymetry data were downloaded as DEMs (30 m resolution) and directly imported as a shape file into ArcView 9.1 using the links and technical assistance provided by National Oceanic and Atmospheric Administration (NOAA) (Betsy Gardner and Robb Wright, NOAA, personal communications). From the bathymetry layer, we retained data pertaining to only 2 contours (i.e., $0 \mathrm{~m}$ and $1 \mathrm{~m}$ depth contours) because Mute Swans forage in shallow water ranging from the surface level to $1.07 \mathrm{~m}$ (Owen and Cadbury 1975). We added these data layers to the previously made maps showing SAV consumption categories and density levels in the Bay. The resultant maps depicted 
spatial proximity of SAV consumption categories and density levels to the shallow water zones represented by $0 \mathrm{~m}$ and $1 \mathrm{~m}$ depth contours (Figs. 5, 6, 7).

After identifying SAV areas that we considered to be under the highest threat due to the presence of widgeon grass or eelgrass beds with higher cover (i.e., 40-100\%) and shallow water (Fig. 8), we further located portions of such areas that may need urgent protection from herbivory. To identify and depict such areas, we depicted distribution of adult Mute Swans in the Bay according to the latest population survey conducted by Maryland DNR in September 2005 and then determined locations of large flocks (n > 50) of Mute Swans (Fig. 9). We premised that the portions of SAV beds at or nearby these locations would be most vulnerable to intensive foraging by Mute Swans and in turn, would need immediate protection. To further refine our search for the portions of SAV beds requiring urgent protection (Fig. 10), we predicted that a) they would be located within the range of daily mean distance traversed by Mute Swans (i.e., $4.25 \mathrm{~km}$ [Sousa 2005]) from each of the locations where large groups of adult Mute Swans were recorded during the survey in fall 2005; b) they also would be located within $1 \mathrm{~km}$ distance from the $0 \mathrm{~m}$ contour, as $0 \mathrm{~m}$ contour represents the shore of the Bay and during the most recent study on Mute Swans' movement patterns in the Bay, it was found that no location of Mute Swans were recorded beyond $1 \mathrm{~km}$ from the shore (Sousa 2005), and c) they also would be located between $0 \mathrm{~m}$ and $1 \mathrm{~m}$ contours as Mute Swans graze from surface level to $1.07 \mathrm{~m}$ depth (Owen and Cadbury 1975). During the most recent study on Mute Swans' movement patterns in the Bay using radio telemetry, Mute Swans were found primarily occur in shallow water (0-1 m) (Sousa 2005). As "selection" tool of the ArcMap did not allow selection of the area between $0 \mathrm{~m}$ and $1 \mathrm{~m}$ contours directly, we 
relied on trial and error to demarcate this area by creating a buffer of appropriate width around the $1 \mathrm{~m}$ contour line. Thus, by creating $0.5 \mathrm{~km}, 1.0 \mathrm{~km}, 1.5 \mathrm{~km}$, and $2.0 \mathrm{~km}$ buffer around $1 \mathrm{~m}$ contour), we found that the buffer of $2 \mathrm{~km}$ width around $1 \mathrm{~m}$ contour that overlapped a portion of previously made $1 \mathrm{~km}$ buffer around $0 \mathrm{~m}$ contour almost entirely covered the zone between $0 \mathrm{~m}$ and $1 \mathrm{~m}$ contours.

For the entire work, we took care that the scale and projections of the bathymetry data would be similar to that of SAV data so that all sources would align properly. All the downloaded data had NAD_1983_UTM_zone_18N projected co-ordinates and GCS_North_American_1983 geographical co-ordinates with the datum of D_North_American_1983. We calculated the area (extent) and proportion of SAV beds under different threat categories to predict the magnitude of potential threat to SAV by Mute Swan herbivory.

\section{RESULTS}

\section{Statistical Modeling}

Table 3 presents the data from the 18 sites that we used to evaluate the predictive models. Of the 15 candidate models, 8 models included swan population as one of its covariates either singly, or in combination with one or more covariates. The remaining seven models did not involve the SP covariate, but we still retained them as we expected that the comparison of AIC values for such models with those involving SP might reveal the significance of swan population as a predictor for SAV decline. The best model (selected using the minimum AICc value $=127.5)$ contained the combined effects of water depth (WD), extent of light penetration (LP), (i.e., light penetration depth relative 
to total depth), salinity (S), and average Mute Swan population (SP) to predict SAV percent cover decline (Y) (Table 1). Thus, the most plausible model (which also was our basic model) was:

$$
\mathrm{Y}=55.2929-10.7255 \mathrm{WD}-38.3855 \mathrm{LP}+8.1752 \mathrm{~S}+0.6477 \mathrm{SP} .
$$

\section{Spatial Modeling}

Areas with only widgeon grass and eelgrass beds covered $203.57 \mathrm{~km}^{2}$, which constituted $81.4 \%$ of SAV area in the Bay. Of this, $107 \mathrm{~km}^{2}(42.8 \%$ of total SAV areas and $52.6 \%$ of SAV areas with widgeon grass and eelgrass) had moderate or high (i.e., $>40-100 \%$ ) cover. Beds of widgeon grass and eelgrass with lower (i.e., 0-40\%) cover occupied $96.57 \mathrm{~km}^{2}$ (i.e., $38.63 \%$ of total SAV areas and $47.4 \%$ of SAV areas with widgeon grass and eelgrass).

The geo-referenced maps show SAV beds of different consumption classes and their proximity to $0 \mathrm{~m}$ and $1 \mathrm{~m}$ depth contours in different parts of the Chesapeake Bay (Figs. 5, 6, 7). Another geo-referenced map shows SAV beds consisting of only widgeon grass and eelgrass with higher (i.e., 40-100\%) cover (Fig. 8).

We found that the beds of the most consumed species with moderate and high (i.e., $>40-100 \%$ ) cover within $1 \mathrm{~km}$ zone of the Bay from shore occupied $70.66 \mathrm{~km}^{2}$ (i.e., $28.26 \%$ of total SAV area and $34.71 \%$ of total area of widgeon grass and eelgrass area). We further determined the proportion of this (i.e., $70.66 \mathrm{~km}^{2}$ ) area that was located between $0 \mathrm{~m}$ and $1 \mathrm{~m}$ contours and found that $100 \%$ of it was located in the shallow water zone between $0 \mathrm{~m}$ and $1 \mathrm{~m}$ contours). 
Portions of the areas that have immediate danger from large flocks of adult Mute Swans also are depicted through a geo-referenced map (Fig. 10). It clearly indicates that the 'urgent protection SAV area' is mainly located in the central Bay between $38^{\circ} 54^{\prime} 30^{\prime \prime}$ $\mathrm{N}$ and $38^{\circ} 58^{\prime} 30^{\prime \prime} \mathrm{N}$ latitudes and $76^{\circ} 13^{\prime} 00^{\prime \prime} \mathrm{W}$ and $76^{\circ} 18^{\prime} 00^{\prime \prime} \mathrm{W}$ longitudes, and also between $38^{\circ} 41^{\prime} 00^{\prime \prime} \mathrm{N}$ and $38^{\circ} 44^{\prime} 00^{\prime \prime} \mathrm{N}$ latitudes and $76^{\circ} 12^{\prime} 00^{\prime \prime} \mathrm{W}$ and $76^{\circ} 14^{\prime} 00^{\prime \prime} \mathrm{W}$ longitudes. A small area also is located in the southern Bay between $38^{\circ} 16^{\prime} 30^{\prime \prime} \mathrm{N}$ and $38^{\circ} 17^{\prime} 00^{\prime \prime} \mathrm{N}$ latitudes $76^{\circ} 05^{\prime} 00^{\prime \prime} \mathrm{W}$ and $76^{\circ} 06^{\prime} 00^{\prime \prime} \mathrm{W}$ longitudes. The total area of 'urgent protection SAV beds' is $2.46 \mathrm{~km}^{2}$.

\section{DISCUSSION}

\section{Statistical Modeling}

In the selected parsimonious model, SAV percent cover decline (Y) had a negative linear relationship with water depth (WD) and extent of light penetration (LP), but had a positive linear relationship with salinity (S) and average Mute Swan population (SP). The model indicates that SAV decline would increase with increasing salinity (S) or average swan population (SP) at a site, and it also would increase with a decrease in depth of water (WD) or decrease in extent of light penetration (LP) at a site. An increase in SAV decline with decreasing water depth was predicted due to the possibility of greater destruction of SAV in shallower water because of its greater exposure to Mute Swan herbivory and other environmental factors (e.g., storms, strong wave action, etc.). An increase in SAV decline with increasing salinity was predicted considering that with the exception of eelgrass (Zostera marina), no SAV species in the Bay is a true sea grass and so increasing salinity would be an adverse environmental condition for most SAV 
species in the Bay (Hurley 1990, Short et al. 2001). Likewise, we predicted that SAV decline would increase with a decrease in extent of light penetration because less light penetration would decrease primary productivity of SAV.

There are no other competing models (as $\triangle \mathrm{AICc}>2.0$; Burnham and Anderson 1998). The Akaike weights (Table 1) indicate that the best model selected based on minimum AICc values is likely as well, with no other models coming close in terms of their relative likelihood. The Akaike weights for all the models in the candidate set sum to 1 (Franklin et al. 2001). Therefore, the best model has a substantial proportion (84.3\%) of the weight associated with all the models. In terms of strength of evidence, the best model is 8 times $(0.843 / 0.108)$ more likely than the second ranked model which did not involve the covariate of swan population. Moreover, the selected parsimonious model was 34 times more likely than the third ranked model which involved the covariate of swan population but not salinity. There was no support for the models involving only number (population) of Mute Swans as a predictor variable or its association with water depth, salinity, or extent of light penetration.

We initially considered inclusion of nutrients (i.e., nitrogen and phosphorus) as one of the potential predictor variables in the basic a priori model, but after careful consideration about the nutrient-rich status of the Bay, we did not include it. We considered that the increasing load of nutrients in water is ultimately linked with light penetration; the variable which We had already included in our basic a priori model. This is because excess amounts of nutrients like phosphorus and nitrogen cause rapid growth of phytoplankton, creating dense blooms, reducing the amount of sunlight available to SAV (Chesapeake Bay Program 2005). Measurement of extent of light 
penetration at 18 study sites (localities) on the eastern shore of the Bay revealed that there was considerable variation in extent of light penetration from site to site. Thus, at 7 sites the extent of light penetration was as high as $100 \%$, at 2 sites it was less than $50 \%$, at another 5 sites its extent was $50 \%$ to $75 \%$, and the remaining 4 sites had between $75 \%$ and $100 \%$ light penetration. Thus, considering variation in extent of light penetration from site to site, the relevant predictor variable (i.e., LP) might have high site-specific (i.e., locality wise) relative importance with respect to growth and survival of SAV in the Bay. In Chesapeake Bay, the most important factor determining growth and survival of SAV is light (Chesapeake Bay Program 2005). In the best model, the highest relative importance of the relevant predictor variable (i.e., extent of light penetration) can be judged from its highest weight (Table 1).

The other 2 predictor variables (i.e., water depth and salinity) also are important in determining growth and survival of SAV in the Bay. This is because SAV is mainly restricted to water less than $2 \mathrm{~m}$ deep and different species of SAV have different salinity requirements (Hurley 1990, Chesapeake Bay Program 2004). Therefore, the most parsimonious model selected appropriately included these 2 predictor variables. However, for the middle portion of the Bay (Talbot and Dorchester Counties), where the maximum population of Mute Swans in the Bay was concentrated (Hindman and Harvey 2004), the locality-wise relative importance of these 2 factors might be lower as compared to that of extent of light penetration. Overall uniformity of water depth and salinity in the mid-Bay was the potential cause for the lower relative importance of these predictor variables. Thus, measurement of environmental factors at 18 study sites in the mid-bay revealed that water depth and salinity were more or less uniform among 
individual sites. At 7 (39\%) sites, water depth was 0.50 to $0.75 \mathrm{~m}$, at another 7 (39\%) sites the depth was $0.75 \mathrm{~m}$ to $<1 \mathrm{~m}$ and only $4(22 \%)$ sites had $1 \mathrm{~m}$ (or slightly more) depth. At 15 (83\%) sites salinity was around 9-10 ppt, and the remaining 3 (17\%) sites had salinity over $10 \mathrm{ppt}$. In our view, the relative importance of the salinity variable also would be low because the widgeon grass covered about $94 \%$ of the total SAV percent cover at the study sites (Chapter 3) indicating its predominance in our study area.

Because widgeon grass is a eury-haline species (Hurley 1990), salinity would not have a substantial impact on its growth and survival.

The relative importance of the predictor variable of the Mute Swan population (i.e., SP) might be lower than that of the other predictor variables because Mute Swans are not the primary cause for SAV decline in the Bay, but an additional factor (Maryland DNR 2001). Accordingly, the weight of this predictor variable was lower than that of other predictor variables in the best selected model (Table 1). Mute Swans likely cause a synergistic effect with abiotic variables, resulting in increased SAV decline in the Bay. Mute Swan control should be used along with other practices to combat SAV decline in the Chesapeake Bay.

\section{Spatial Modeling}

Spatial modeling revealed that the proportion of the SAV beds that only have widgeon grass or eelgrass (or both) is $97 \%$ higher than that of the beds that have a combination of any of these 2 species and other species that do not constitute important food of Mute Swans. Moreover, the proportion of the SAV beds that only have widgeon grass or eelgrass (or both) is $80 \%$ higher than that of the beds having species other than 
these 2 species. However, it may be noted that although widgeon grass can adapt to many parts of the Bay due its tolerance to salinity variation and eelgrass is persistent in highly saline waters (Hurley 1990, Maryland DNR 2005), herbivory by exotic Mute Swans in the Bay is detrimental (Chapter 3). In Maryland, Mute Swans almost exclusively feed on widgeon grass apart from eelgrass in the southern portion of the Bay (Hindman and Harvey 2004) and so it can be inferred that the overall decline in SAV had also caused a decline in widgeon grass and eelgrass cover. It is likely that these 2 species are most commonly consumed because they are the most abundant and widespread species. Therefore, herbivory also can be detrimental to some other species of SAV that have comparatively limited distribution in the Bay.

The spatial modeling revealed that about $52.6 \%$ of the SAV areas with the species that are important for Mute Swans also had high SAV cover. Such areas should be given high priority for protecting SAV from Mute Swan herbivory.

The highest priority for the immediate protection of SAV from Mute Swan herbivory may be given to the 'urgent protection SAV areas'. It should be noted that such areas may change or expand in the future as Mute Swans congregate in other shallow areas with beds of widgeon grass or eelgrass and higher cover. Therefore, it would be useful to determine 'urgent protection areas' after each Mute Swan survey using GIS modeling as presented in this chapter. The spatial modeling has indicated that the proportion of SAV areas with high density beds is considerable in the Bay, providing enough space for several Mute Swan congregations. Though we have used 'most important species' as one of the factors in spatial model development, density may be a more important factor due to the possibility that irrespective of the species, higher density 
of SAV would lead to more food availability for Mute Swans that can also feed on other species like sago pondweed (Stuckenia pectinata) and horned pondweed (Zannichellia palustris) (Ciaranca et al. 1997). In turn, it also is likely that if species other than widgeon grass or eelgrass occur at high density, those species would be more vulnerable compared to the low density beds of widgeon grass and eelgrass. Because Mute Swans feed in waters $\leq 1.07 \mathrm{~m}$ deep and the Mute Swan population has undergone a dramatic increase in the Bay after the late 1980s, water depth and swan population also are important factors in developing spatial models to predict SAV decline due to herbivory.

The statistical modeling indicated that although Mute Swan herbivory is not the most important factor influencing SAV decline in the Bay, it certainly contributes to SAV decline. Therefore, Mute Swan impacts should be incorporated into a larger framework of SAV protection in the Chesapeake Bay. Mute Swan population should be controlled by increasing the intensity of the egg addling program and removal of adult Mute Swans from the SAV areas having beds with high cover of widgeon grass and eelgrass. Mute Swan exclosures may be constructed in such areas with dual purpose of protecting SAV beds from herbivory and monitoring the SAV decline from year to year. 


\section{ACKNOWLEDGEMENTS}

Funding for this work was provided by Federal Aid in Wildlife Restoration, grantW-61-R to Maryland DNR and Maryland Migratory Game Bird Stamp Funds. Thanks to Dr. George Seidel, Assistant Professor, Division of Statistics, for helping with statistical work. We thank Andrew Isner, Jon Chandler, Troy Osborne, Joseph Osbourne, Seth Lemley, Dave Helon, and Collin Balcombe of West Virginia University for field assistance and property owners for allowing access to the Bay. We are also thankful to Brent Evans and Michael Naylor of Maryland DNR in helping me to have an access to the GIS data that we needed. Thanks to Davis Wilcox of VIMS and Betsy Gardner and Robb Wright of NOAA in providing relevant GIS data and providing technical assistance

in using them. Last but not the least, we are indebted to Dr. Michael Strager, Assistant Professor, Division of Forestry for his timely help in solving GIS related problems. 


\section{LITERATURE CITED}

Bellrose, F. C. 1980. Ducks, geese and swans of North America. Stackpole Books, Harrisburg, Pennsylvania, USA.

Burnham, K. P. and D. R. Anderson. 1998. Model selection and inference: a practical information theoretic approach. Singer-Verlag, New York, USA.

Chesapeake Bay Program. 2004. Preserving and restoring bay grasses.

$<$ http://www.chesapeakebay.net/restrtn.htm>

Chesapeake Bay Program 2005. Nutrient pollution.

$<$ http://www.chesapeakebay.net/nutr1.htm>

Ciaranca, M. A., C. C. Allin, and G. S. Jones. 1997. Mute Swan (Cygnus olor). Pages

1-26 in A. Poole and F. Gill, editors. The Birds of North America, No. 273. The Academy of Natural Sciences, Philadelphia, Pennsylvania, and The American Ornithologists' Union, Washington, D.C., USA.

Franklin, A. B., T. M. Shenk, D. R. Anderson, and K. P. Burnham. 2001. Statistical model selection: an alternative to null hypothesis testing. Pages 75-90 in Shenk, T. M. and A. B. Franklin, editors. Modeling in natural resource managementdevelopment, interpretation, and application. Island Press, Washington, USA.

Hindman, L. J. and V. D. Stotts. 1989. Chesapeake Bay and North Carolina Sounds. Pages 27-55 in L. M. Smith, R. L. Pederson and R. M. Kaminski, editors. Habitat management for migrating and wintering waterfowl in North America. Texas Tech University Press, Lubbock, Texas, USA.

Hindman, L. J. and W. F. Harvey. 2004. Status and management of Mute Swans in Maryland. Pages 11-17 in M. C. Perry, editor. Mute Swans and their Chesapeake 
Bay habitats: Proceedings of a Symposium: U. S. Geological Survey, Biological Resources Discipline Information and Technology Report USGS/BRD/ITR2004-0005.

Hurley, L. M. 1990. Field guide to the submerged aquatic vegetation of Chesapeake Bay, U. S. Fish and Wildlife Service, Washington, D.C., USA.

Johnson, L. B. 1990. Analyzing spatial and temporal phenomena using geographical information systems- A Review of Ecological Applications. Landscape Ecology 4:31-43.

Mangel, M., O. Fiksen, and J. Giske. 2001. Theoretical and statistical models in natural resource management and research. Pages 57-72 in Shenk, T. M. and A. B. Franklin, editors. Modeling in natural resource management-development, interpretation, and application. Island Press, Washington.

Maryland Department of Natural Resources. 2001. Mute Swans-population status, impacts on native wildlife and people, and management needs in Maryland. Mute Swan Task Force 2001. A summary of information prepared by the Maryland Department of Natural Resources, Annapolis, Maryland, USA. $<$ http://www.dnr.state.md.us/wildlife/mstfpc.html $>$

Maryland Department of Natural Resources. 2002. Mute Swan population survey shows decline. Maryland Department of Natural Resources, Annapolis, Maryland, USA. $<$ http://www.dnr.state.md.us/wildlife/mutereport2002.html>

Maryland Department of Natural Resources. 2005. Bay grass identification key. Maryland Department of Natural Resources, Annapolis, Maryland, USA. $<$ http://www.dnr.state.md.us/bay/sav/key> 
Meyers, E., R. Fischman and A. Marsh. 1995. Maryland Chesapeake Bay critical areas program: wetland protection and future growth. Pages 189-201 in D. R. Porter and D. A. Salvesen, editors. Collaborative planning for wetlands and wildlifeissues and examples. Island Press, Washington D.C., USA.

Naylor, M. 2004. Potential impacts of Mute Swans to SAV in Chesapeake Bay. Pages 36-37 in M. C. Perry, editor. Mute Swans and their Chesapeake Bay habitats: Proceedings of a Symposium: U. S. Geological Survey, Biological Resources Discipline Information and Technology Report USGS/BRD/ITR- 2004-0005.

Owen, M. and C. J. Cadbury. 1975. The ecology and mortality of Mute Swans at the Ouses Washes, England. Wildfowl 25:31-42.

Orth, R. J., D. J. Wilcox, L. S. Negey, J. R. Whiting, and J. R. Fishman. 2003. 2003 distribution of submerged aquatic vegetation in the Chesapeake Bay and Coastal Bay, Glouchester, Virginia, Virginia Institute of Marine Science, Special Scientific Report No. 144.

Perry, M. C., P. C. Osenton, and E. J. R. Lohnes. 2004. Food habits of Mute Swans in Chesapeake Bay. Pages 31-36 in M. C. Perry, editor. Mute Swans and their Chesapeake Bay habitats: Proceedings of a Symposium:U. S. Geological Survey, Biological Resources Discipline Information and Technology Report USGS/BRD/ITR- 2004-0005.

SAS Institute, Inc. 2001. SAS/STAT software. Cary, North Carolina, USA.

Scott, P. 2004. Review of the status of Mute Swans on the Canadian side of the Lower Great Lakes. Pages 23-27 in M. C. Perry, editor. Mute Swans and their Chesapeake Bay habitats: Proceedings of a Symposium: U. S. Geological Survey, 
Biological Resources Discipline Information and Technology Report USGS/BRD/ITR-2004-0005.

Short, F. T., R. G. Coles, and C. P. Martini. 2001. Global seagrass distribution. Pages 630 in F. T. Short and R. G. Coles, editors. Global sea grass research methods, Elsevier, Amsterdam, The Netherlands.

Sklar, F. H. and C. T. Hunsaker. 2001. The use and uncertainties of spatial data for landscape models: an overview with examples from the Florida Everglades. Pages 15-46 in C. T. Hunsaker, M. F. Goodchild, M. A. Friedl, and T. J. Case, editors. Spatial uncertainty in ecology- implications for remote sensing and GIS applications, Springer, New York, USA.

Sousa, C. 2005. Assessing the impact of Mute Swans in the Chesapeake Bay area of Maryland. Thesis, Cornell University, New York, USA.

Stine, P. A. and C. T. Hunsaker. 2001. An introduction to uncertainty issues for spatial data used in ecological applications. Pages 91-107 in C. T. Hunsaker, M. F. Goodchild, M. A. Friedl, and T. J. Case, editors. Spatial uncertainty in ecologyimplications for remote sensing and GIS applications, Springer, New York, USA. 
Table 1. Ranking of 15 a priori candidate models relating Submerged Aquatic Vegetation cover decline to predictor variables (water depth [WD], light penetration [LP], salinity [S], and Mute Swan population [SP]) for Chesapeake Bay, Maryland, 2003-04. Models were ranked using Akaike's Information Criterion for small sample size (AICc).

\begin{tabular}{|c|c|c|c|c|c|}
\hline Model structure & $\begin{array}{l}\text { Equation } \\
\mathrm{Y}=\text { Decline in percent } \\
\text { cover }\end{array}$ & $\overline{\mathrm{AICc}}$ & $\overline{\triangle \mathrm{AICc}}$ & $\overline{\mathrm{K}}$ & $\overline{w_{i}}$ \\
\hline $\mathrm{Y}=\mathrm{WD} \pm \mathrm{LP} \pm \mathrm{S} \pm \mathrm{SP}$ & $\begin{array}{l}55.2929-10.7255 \mathrm{WD} \\
-38.3855 \mathrm{LP}+8.1752 \mathrm{~S} \\
+0.6477 \mathrm{SP}\end{array}$ & 127.5 & 0 & 6 & 0.8430 \\
\hline $\mathrm{Y}=\mathrm{WD} \pm \mathrm{LP} \pm \mathrm{S}$ & $\begin{array}{l}28.127-0.2264 \mathrm{WD} \\
-21.0908 \mathrm{LP}+3.3922 \mathrm{~S}\end{array}$ & 131.6 & 4.1 & 5 & 0.1080 \\
\hline $\mathrm{Y}=\mathrm{WD} \pm \mathrm{LP} \pm \mathrm{SP}$ & $\begin{array}{l}39.4587-5.0608 \mathrm{WD} \\
-27.1802 \mathrm{LP}+0.5804 \mathrm{SP}\end{array}$ & 134.5 & 7.0 & 5 & 0.0250 \\
\hline $\mathrm{Y}=\mathrm{LP} \pm \mathrm{S} \pm \mathrm{SP}$ & $\begin{array}{l}35.7047-33.6013 \mathrm{LP} \\
+7.5071 \mathrm{~S}+0.6303 \mathrm{SP}\end{array}$ & 136.0 & 8.5 & 5 & 0.0120 \\
\hline $\mathrm{Y}=\mathrm{WD} \pm \mathrm{S} \pm \mathrm{SP}$ & $\begin{array}{l}40.0742-6.8446 \mathrm{WD} \\
+3.3218 \mathrm{~S}+0.5424 \mathrm{SP}\end{array}$ & 137.8 & 10.3 & 5 & 0.0050 \\
\hline $\mathrm{Y}=\mathrm{WD} \pm \mathrm{LP}$ & $\begin{array}{l}66.1595-1.7946 \mathrm{WD} \\
-16.9337 \mathrm{LP}\end{array}$ & 137.9 & 10.4 & 4 & 0.0050 \\
\hline $\mathrm{Y}=\mathrm{LP} \pm \mathrm{S}$ & $\begin{array}{l}28.5030-20.9971 \mathrm{LP} \\
+3.3805 \mathrm{~S}\end{array}$ & 140.2 & 12.7 & 4 & 0.0020 \\
\hline $\mathrm{Y}=\mathrm{WD} \pm \mathrm{S}$ & $76.6266-9.1784 \mathrm{WD}$ & 142.7 & 15.2 & 4 & 0 \\
\hline
\end{tabular}


$+0.9758 \mathrm{~S}$

\begin{tabular}{|c|c|c|c|c|c|}
\hline $\mathrm{Y}=\mathrm{LP} \pm \mathrm{SP}$ & $\begin{array}{l}45.2999-25.2724 \mathrm{LP} \\
+0.5746 \mathrm{SP}\end{array}$ & 142.9 & 15.4 & 4 & 0 \\
\hline $\mathrm{Y}=\mathrm{WD} \pm \mathrm{SP}$ & $\begin{array}{l}72.9620-7.1079 \mathrm{WD} \\
+0.5244 \mathrm{SP}\end{array}$ & 143.9 & 16.4 & 4 & 0 \\
\hline $\mathrm{Y}=\mathrm{S} \pm \mathrm{SP}$ & $\begin{array}{l}33.8981+3.3724 \mathrm{~S} \\
+0.5458 \mathrm{SP}\end{array}$ & 146.1 & 18.6 & 4 & 0 \\
\hline $\mathrm{Y}=\mathrm{LP}$ & $64.1566-17.5823 \mathrm{LP}$ & 146.5 & 19.0 & 3 & 0 \\
\hline $\mathrm{Y}=\mathrm{WD}$ & $86.1549-9.2344 \mathrm{WD}$ & 146.7 & 19.2 & 3 & 0 \\
\hline $\mathrm{Y}=\mathrm{S}$ & $68.6378+1.0239 \mathrm{~S}$ & 149.2 & 21.7 & 3 & 0 \\
\hline $\mathrm{Y}=\mathrm{SP}$ & $67.0658+0.5277 \mathrm{SP}$ & 152.2 & 24.7 & 3 & 0 \\
\hline
\end{tabular}


Table 2. Data layers used for spatial model development using ArcGIS 9.

\begin{tabular}{llll}
\hline Data & Source & Data type & Scale/Resolution \\
\hline SAV bed & VIMS & Vector-polygon & $1: 24,000$ \\
Chesapeake & NOAA & Raster grid & 30 m cell \\
bathymetry (DEM) & & & \\
& & & \\
Mute Swan & Maryland & DBF & \\
location & DNR & & \\
co-ordinates & (Fall 2005 & & \\
& survey results) & & \\
\hline
\end{tabular}


Table 3. Localized data on Mute Swan population and other environmental variables used to predict the best approximating model for Submerged Aquatic Vegetation decline using information theoretic approach (Burnham and Anderson 1998) on the Chesapeake Bay, Maryland, 2003-04.

\begin{tabular}{|c|c|c|c|c|}
\hline$W D^{a}$ & $L P^{b}$ & $\overline{S^{C}}$ & $S P^{d}$ & $\overline{Y^{e}}$ \\
\hline 0.95 & 77.40 & 9.20 & 2 & 55.55 \\
\hline 0.75 & 100.00 & 9.24 & 44 & 100.00 \\
\hline 0.79 & 100.00 & 10.20 & 7 & 63.05 \\
\hline 0.75 & 68.30 & 9.70 & 22 & 88.88 \\
\hline 0.69 & 74.30 & 10.44 & 44 & 92.62 \\
\hline 0.91 & 93.50 & 9.03 & 2 & 36.71 \\
\hline 0.59 & 100.00 & 9.73 & 27 & 83.17 \\
\hline 1.00 & 43.70 & 11.26 & 2 & 76.92 \\
\hline 0.97 & 100.00 & 9.96 & 2 & 89.88 \\
\hline 0.64 & 100.00 & 8.65 & 12 & 88.93 \\
\hline 0.95 & 96.40 & 9.46 & 48 & 92.86 \\
\hline 1.10 & 65.40 & 9.50 & 50 & 81.20 \\
\hline 1.02 & 50.20 & 9.60 & 30 & 92.96 \\
\hline 1.07 & 93.50 & 9.60 & 9 & 90.54 \\
\hline 0.50 & 100.00 & 10.62 & 10 & 75.00 \\
\hline 0.76 & 62.00 & 9.66 & 18 & 31.58 \\
\hline 0.77 & 52.70 & 9.73 & 39 & 75.07 \\
\hline 0.54 & 100.00 & 9.38 & 25 & 100.00 \\
\hline
\end{tabular}


${ }^{\mathrm{a}}$ Total water depth $(\mathrm{m})$.

${ }^{b}$ Extent of light penetration $=[$ Secchi depth/Total water depth $] \times 100$.

${ }^{\mathrm{c} S a l i n i t y ~ o f ~ w a t e r ~(p p t) . ~}$

${ }^{\mathrm{d}}$ Mute Swan population.

${ }^{\mathrm{e}}$ Decline in SAV percent cover due to Mute Swan herbivory, i.e. \% difference in SAV cover in exclosure and open plots. 


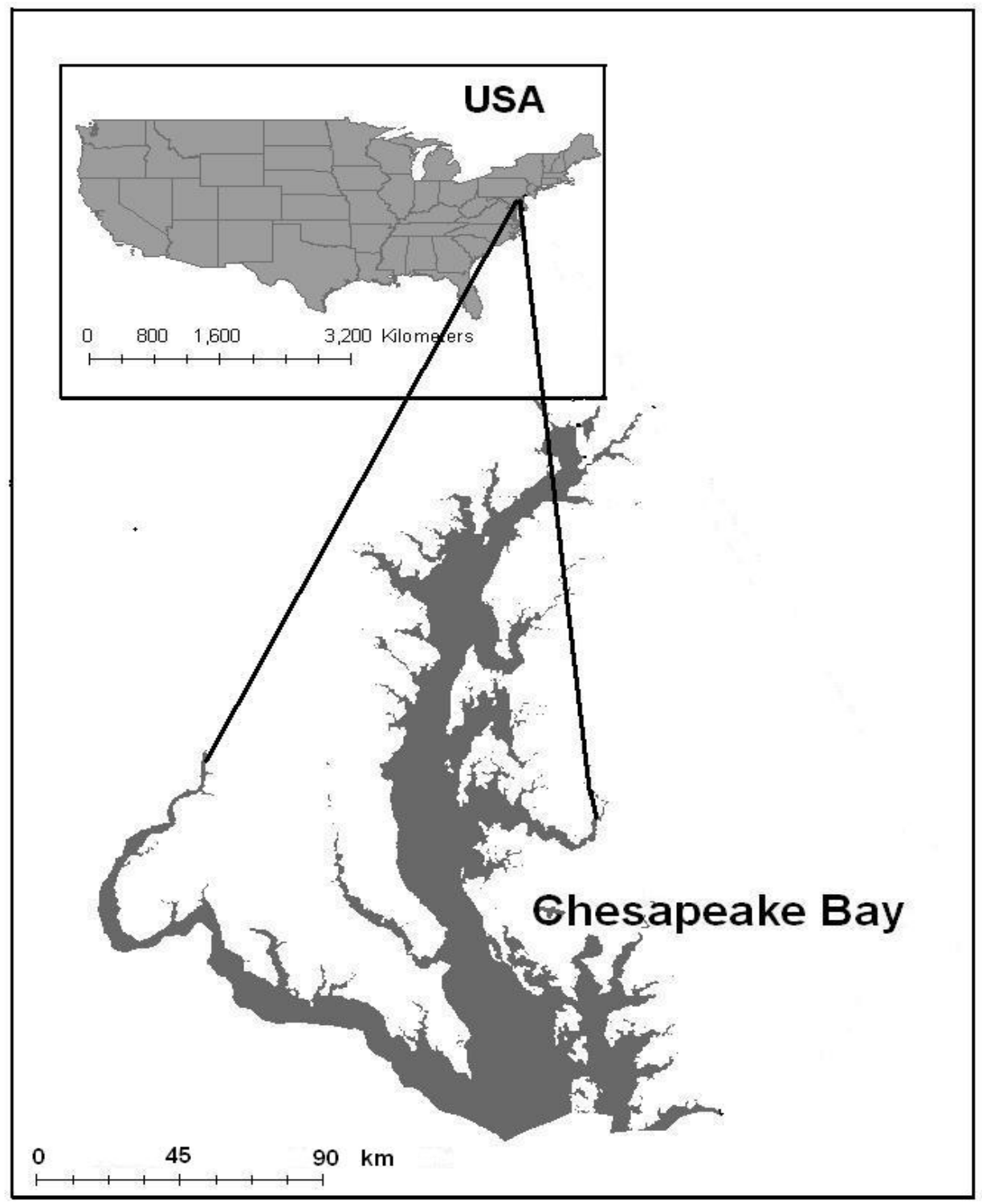

Figure 1. We conducted the Mute Swan-Submerged Aquatic Vegetation study on the Chesapeake Bay, USA. 


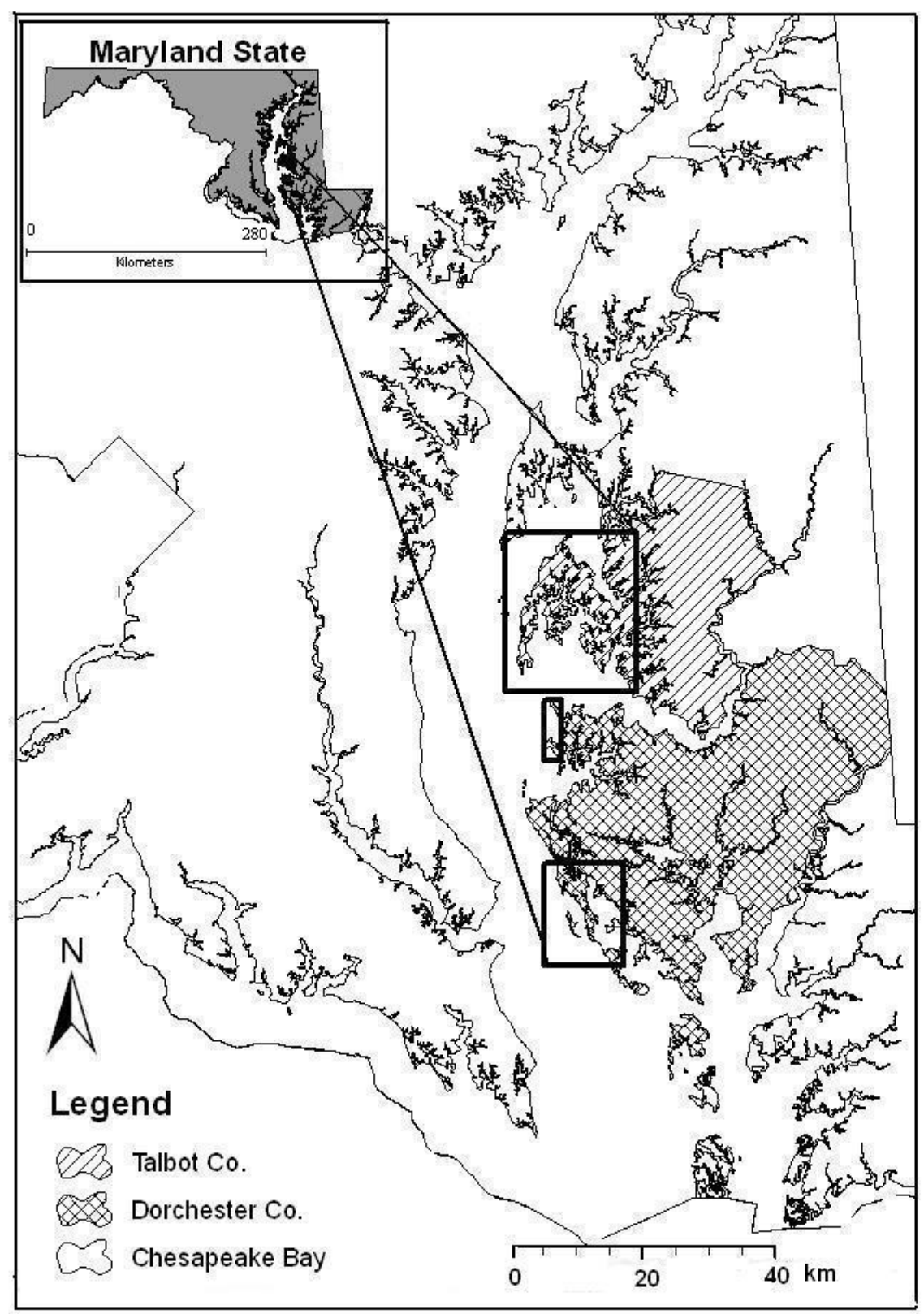

Figure 2. Portions of Talbot and Dorchester Counties, Maryland (marked) on the eastern shore of the Chesapeake Bay where 18 sites for data collections were located, 2003-04. 


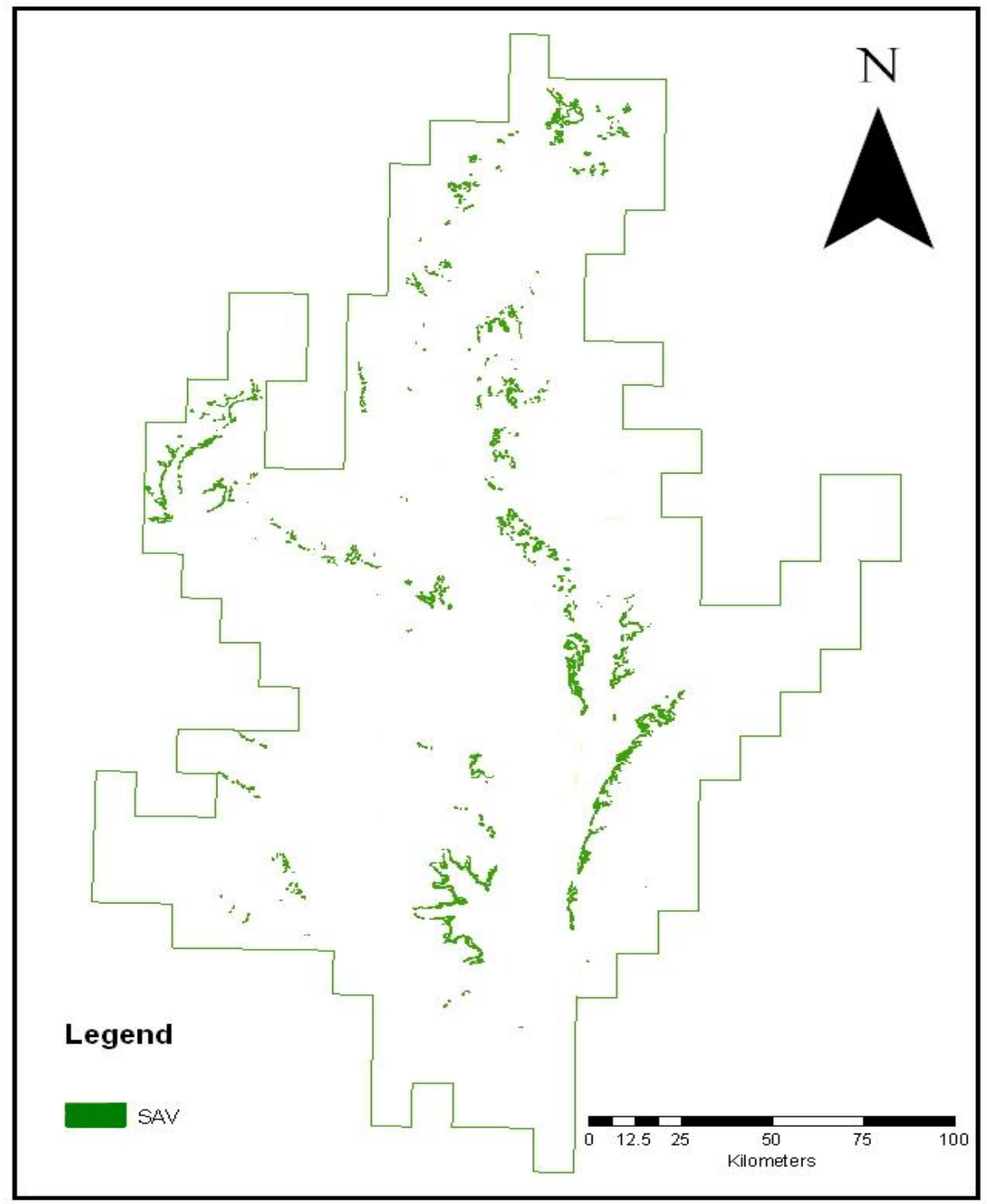

Figure 3. The data layer of Submerged Aquatic Vegetation (SAV) bed in the Chesapeake Bay that formed the basis for the GIS based modeling was down-loaded from the link (ftp://ftp.vims.edu/incoming/dwilcox/sav03 04.zip) provided by Virginia Institute of Marine Sciences (VIMS). 


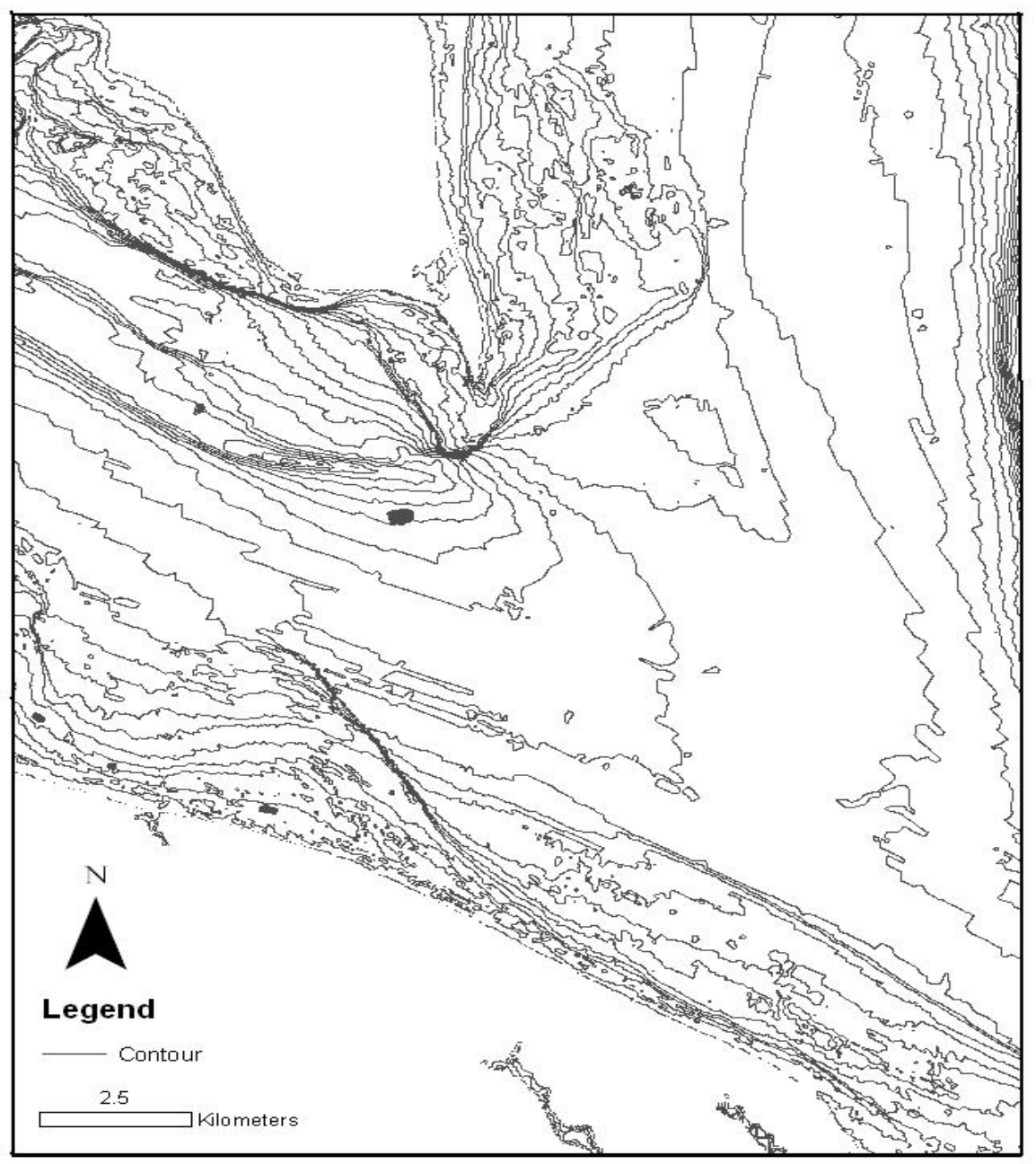

Figure 4. Bathymetry shape file of the Chesapeake Bay that was used to identify and depict 0 and $1 \mathrm{~m}$ contours was downloaded from the link (ftp://spo.nos.noaa.gov/public/wright/m130_grid.zip) provided by National Oceanic and Atmospheric Administration (NOAA). 


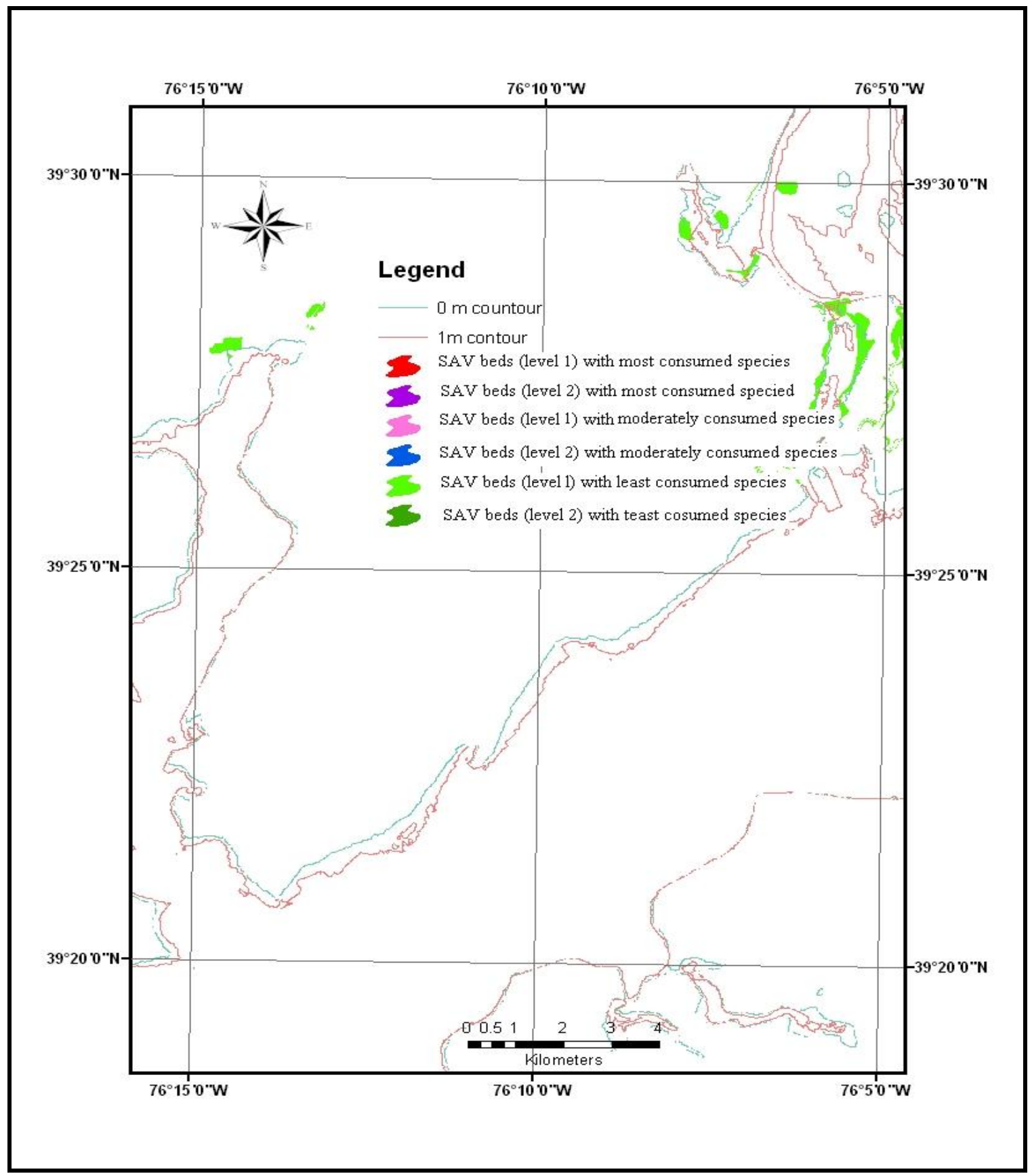

Figure 5. A portion of northern Chesapeake Bay depicting proximity of $0 \mathrm{~m}$ and $1 \mathrm{~m}$ depth contours to Submerged Aquatic Vegetation (SAV) beds with the species that are potentially least consumed by Mute Swans. 


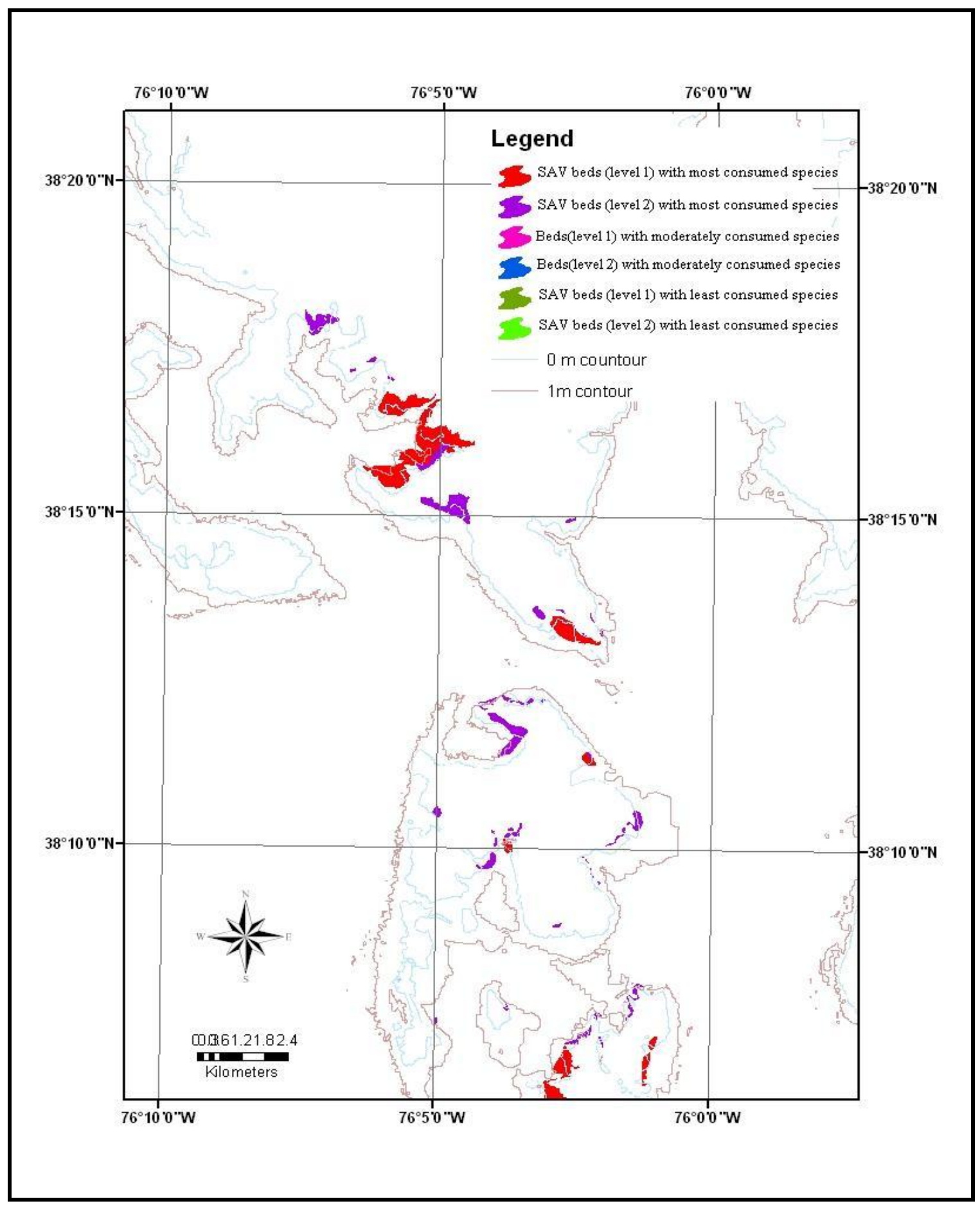

Figure 6. A portion of central Chesapeake Bay depicting proximity of $0 \mathrm{~m}$ and $1 \mathrm{~m}$ depth contours to Submerged Aquatic Vegetation (SAV) beds (with the species that are potentially most consumed by Mute Swans). 


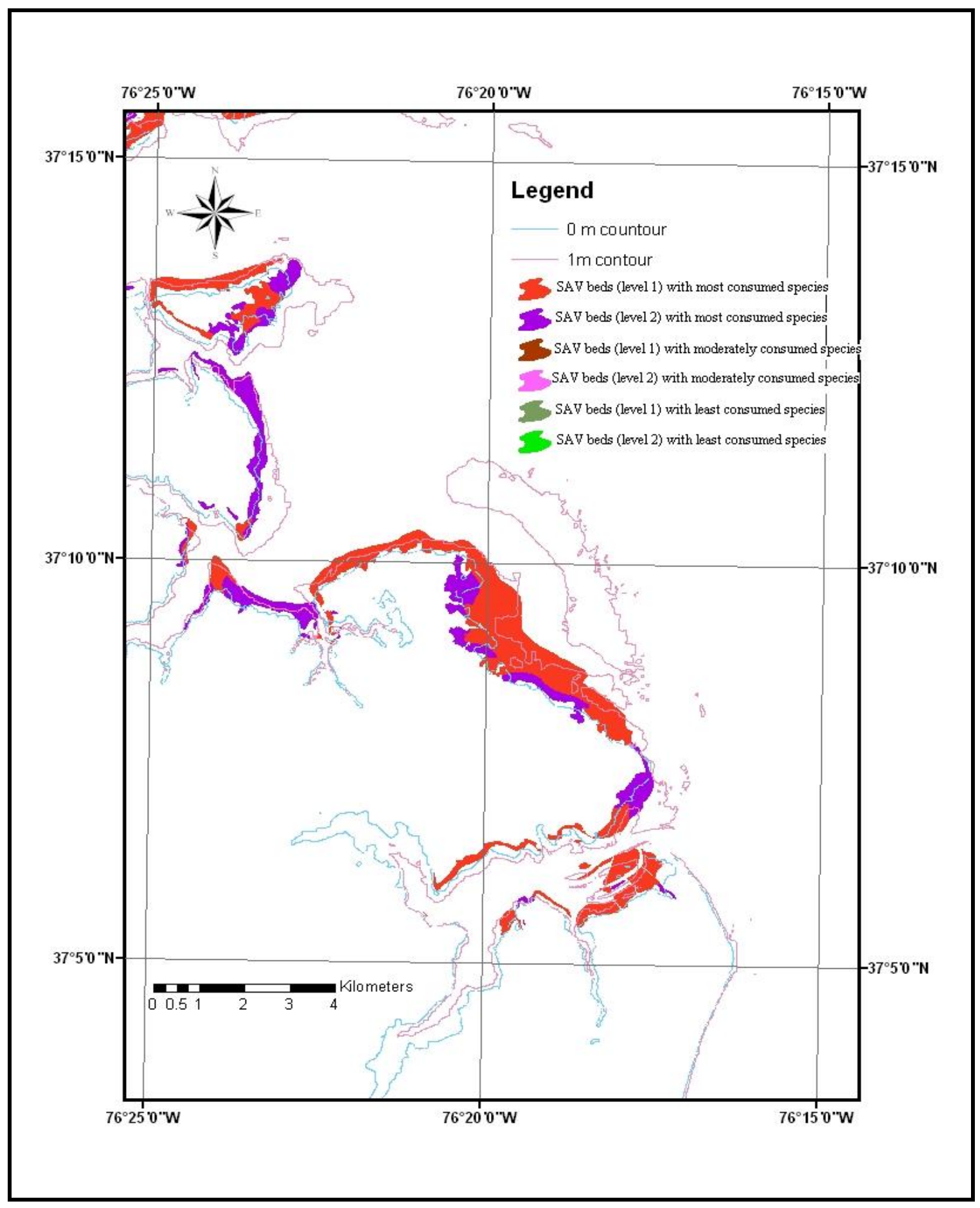

Figure 7. A portion of southern Chesapeake Bay depicting proximity of $0 \mathrm{~m}$ and $1 \mathrm{~m}$ depth contours to Submerged Aquatic Vegetation (SAV) beds (with the species that are potentially most consumed by Mute Swans). 


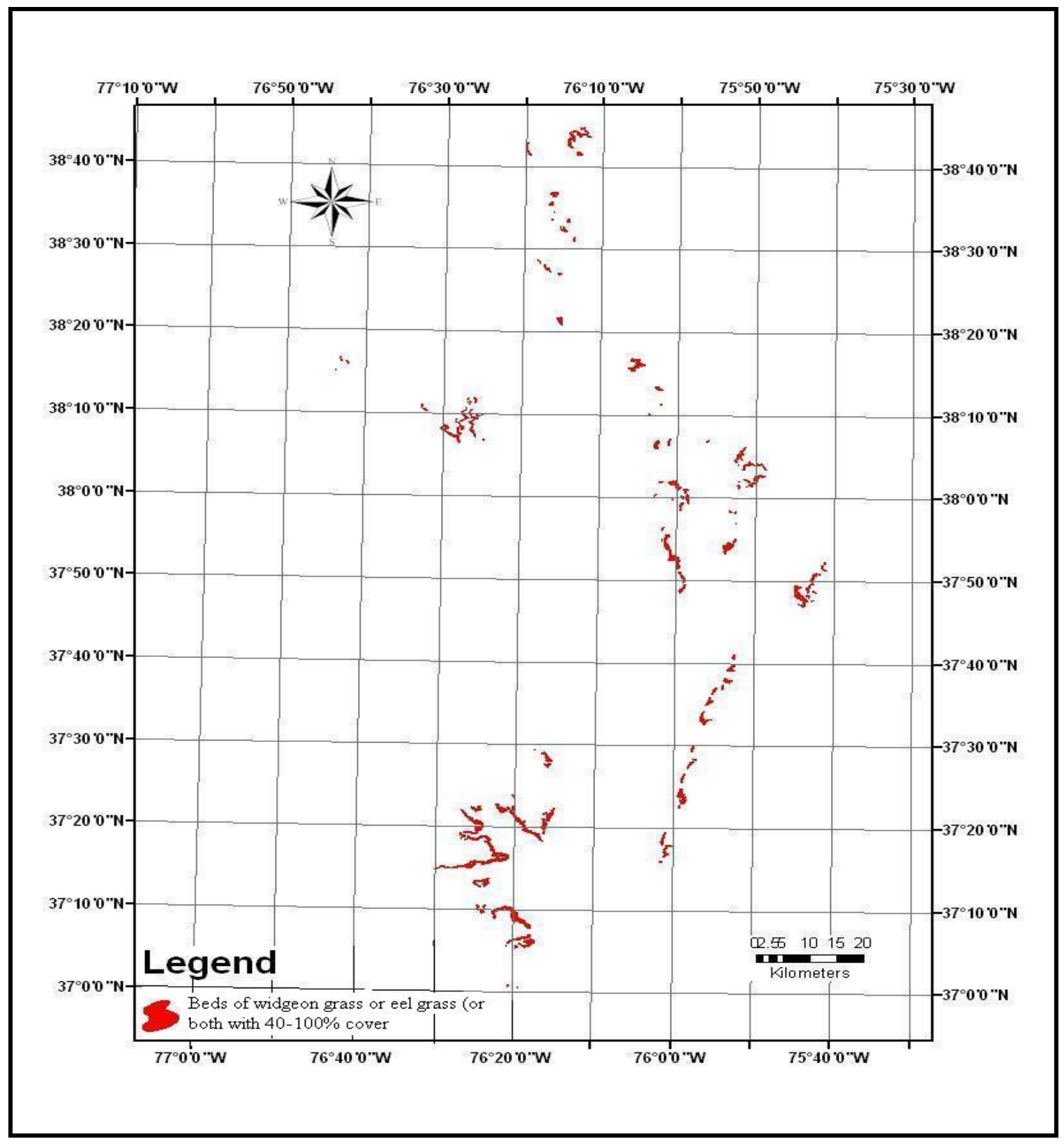

Figure 8 . Beds with $40-100 \%$ cover of widgeon grass and eelgrass that potentially have highest threat from Mute Swan herbivory. 


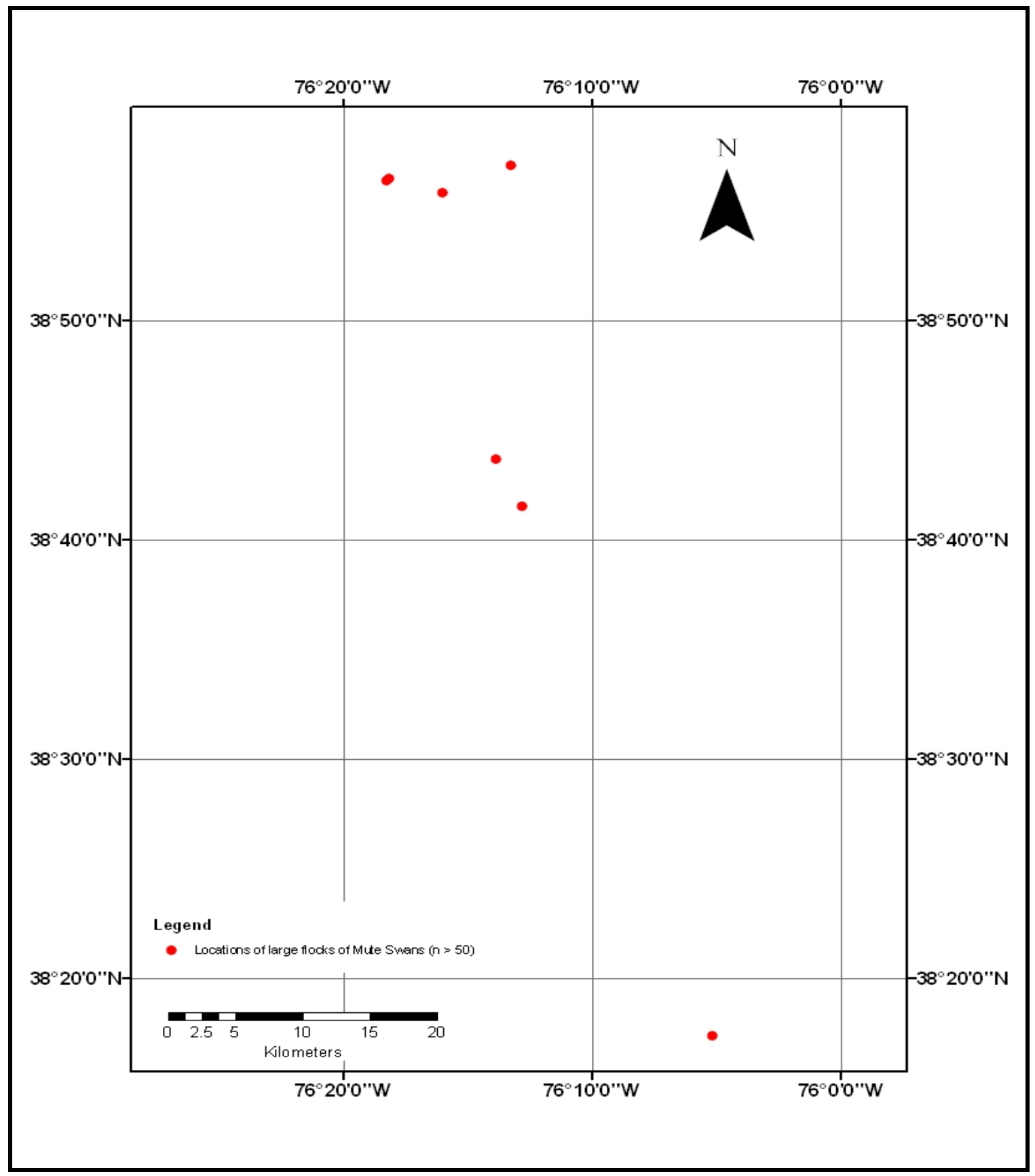

Figure 9. Locations of large flocks of adult Mute Swans in the Chesapeake Bay (based on the survey conducted by Maryland DNR in September 2005). 


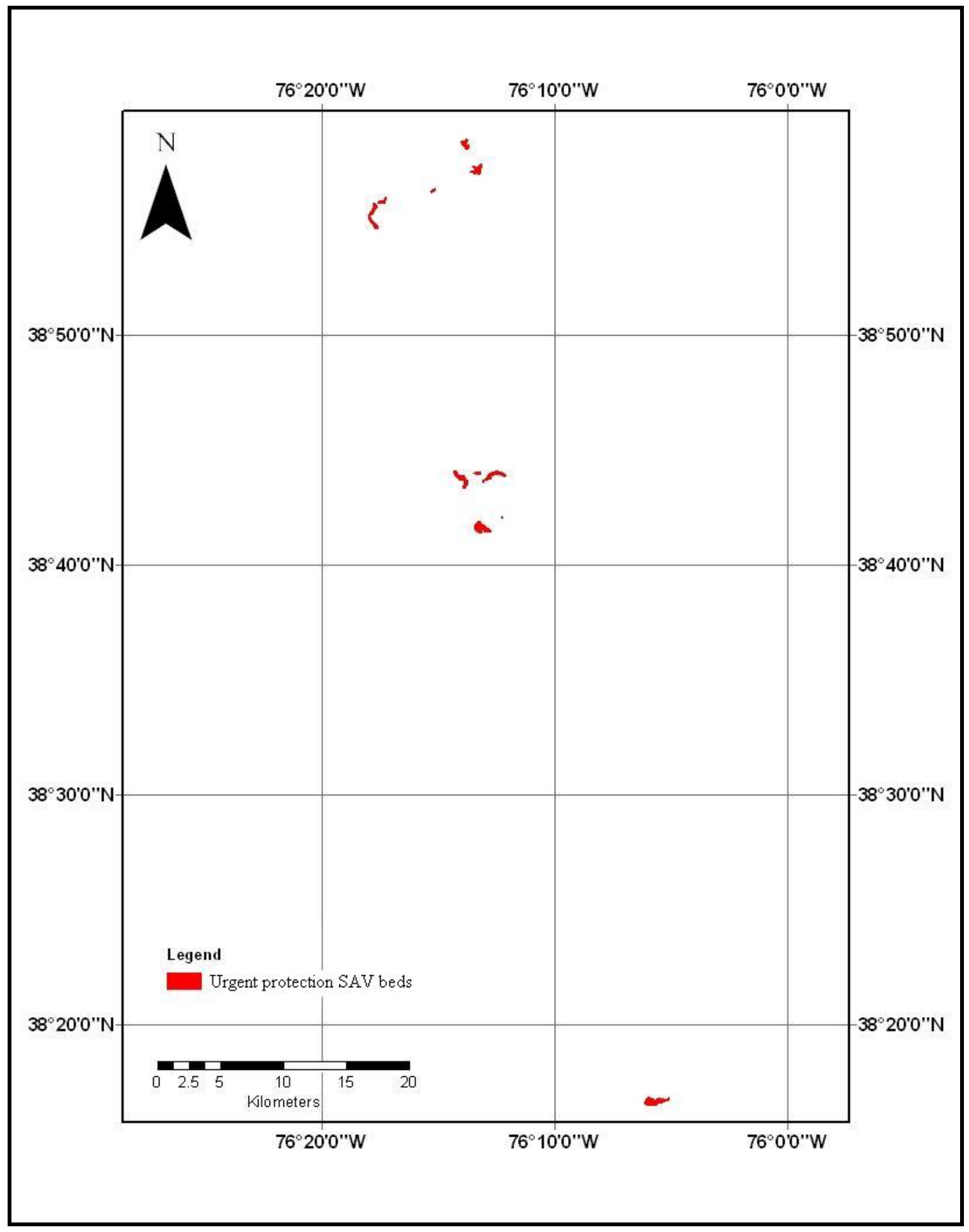

Figure 10. 'Urgent protection SAV areas' (identified based on presence of large flocks of adult Mute Swans during the latest Mute Swan survey in September 2005). 


\section{CHAPTER V}

\section{MANAGEMENT IMPLICATIONS AND FUTURE RESEARCH}

KETAN S. TATU

ktatu@mix.wvu.edu

West Virginia University

Division of Forestry

P. O. Box 6125

Morgantown, WV 26506-6125 


\section{MANAGEMENT IMPLICATIONS AND FUTURE RESEARCH}

\section{Management Implications}

Submerged aquatic vegetation (SAV) has historically contributed to the high primary and secondary productivity of the Chesapeake Bay (Kemp et al. 1983). The communities of the submerged aquatic plants in the Bay also are key contributors to the energy cycling in the Bay (Chesapeake Bay Program 2004). Moreover, SAV provides crucial habitat and food for a host of aquatic organisms including fish, shellfish, invertebrates, and waterfowl (Hurley 1990, Chesapeake Bay Program 2004). Thus, SAV has undoubtedly played a crucial role in maintaining the overall health of the Chesapeake Bay ecosystem and therefore bay-wide or localized reduction of SAV is undesirable. This dramatic bay-wide decline of all SAV species in the late 1960s and into the 1970s (Orth and Moore 1983) caused serious concerns among diverse groups of professionals and citizens, and that led to the formulation of a policy and implementation plan to ensure the future of SAV in Chesapeake Bay. Since then, SAV and its decline in the Chesapeake Bay has been a critical and often sensitive issue among biologists and citizens who are concerned about the health of the Chesapeake Bay ecosystem in general and SAV in particular.

An increasing human population and increasing loads of sediments, wastes, and pollutants resulting from domestic, industrial, and agricultural activities in the Bay's watershed have been largely considered responsible for the bay-wide decline of SAV (Hurley 1990, Feral 2004). Thus, the widespread SAV decline in the 1960s and 1970s was solely correlated with increasing nutrient and sediment inputs from development activities in the surrounding watershed (Kemp et al. 1983). Unfortunately, the potential 
harmfulness of nutrient enrichment, pollution, and sedimentation is so much that other possible factors, like herbivory by invasive Mute Swans (Cygnus olor) that may further aggravate the situation, were underestimated at least in the past. Thus, Stevenson et al. (1979) opined that it is unlikely that Mute Swans represented a threat serious enough to decimate the submerged aquatic plants throughout the Bay considering their small numbers (i.e., 200-300 individuals as per a June 1977 count) limited mainly to Eastern Bay and to the Little Choptank and Chester rivers. This is a good example of underestimation of a factor that had the potential to become a serious problem for SAV and ecology of the Chesapeake Bay in the future. In fact, Reese (1980) had appropriately remarked that the Chesapeake Bay is a primary waterfowl wintering area in the Atlantic Flyway and a large sedentary population of an aggressive, vegetarian waterfowl, individuals of which are larger than any of our native species, could have a detrimental effect on the Chesapeake Bay's ecology and the future of native waterfowl.

During subsequent years, the Mute Swan population increased drastically from 264 birds in 1986 to 3,955 birds in 1999 in the Maryland portion of the Bay (Hindman and Harvey 2004). The present day population is as high as 2,224 individuals (Larry Hindman, Maryland DNR, personal communication) despite population control measures taken by government agencies. Underestimating the potential of the Mute Swan population to grow rapidly might have been justifiable in the late 1970s, since such growth was not previously experienced in the Bay. Nonetheless, Reese (1980) had rightly predicted that demographic functions of the Chesapeake Bay population of Mute Swans had shown that the population was experiencing unrestricted growth even during 1980s. However, many people continued to underestimate the impact of Mute Swan 
populations even today. Thus, some individuals and organizations opposing Mute Swan population control through lethal techniques emphasized that Mute Swans, unlike vast number of wintering waterfowl, have limited potential to over-consume SAV as there are barely 4,000 Mute Swans in the Bay (Feral 2004, Markarian and Lovvorn 2004). This is another good example of underestimating the influence of the Mute Swan population in the Bay. Such predictions also ignore the fact that unlike wintering waterfowl, Mute Swans live in the Bay all year-round consuming SAV not just during winter, but also during its growing season (Hindman and Harvey 2004, Naylor 2004). Consumption of SAV during the growing season is probably more problematic because it reduces future reproductive potential. Such predictions also do not take into account the possibility of a further population increase if the population is not controlled at this stage. Moreover, these misguided predictions were not based on quantitative data indicating that Mute Swans do not cause SAV reduction through foraging. On the contrary, data generated in my study during 2003 and 2004 have clearly showed that Mute Swan herbivory caused localized SAV reduction (Chapter 3). My exclosure study quantitatively showed that Mute Swan herbivory leads to considerable reduction in cover, shoot density, and canopy height of SAV (Chapter 3). In addition to my exclosure study, my time-and-activity budget study has quantitatively revealed that feeding is indeed an intense activity of Mute Swans in the Chesapeake Bay, Maryland irrespective of seasonal and diurnal time periods (Chapter 2). As SAV is known to be the main diet item of these exotic swans (Hindman and Harvey 2004), high feeding intensity is indeed a matter of concern.

I believe that Mute Swans might not constitute a serious threat to SAV if the SAV was not under the adverse effect of pollution, sedimentation, and nutrient enrichment in 
the Bay. But, unfortunately it is a stressed resource in the Bay (Naylor 2004) and Mute Swans contribute to its overall reduction as they exhibit a strong preference for SAV as a food (Fenwick 1983). Therefore every possible step should be taken to protect it. Mute Swan control is one such measure (Chapters 2,3) even though it may be against the aesthetic taste of some people or appears inhumane to others (Feral 2004, Markarian and Lovvorn 2004). Although it will not be a total solution to the bay-wide SAV decline, it will help in reducing localized SAV decline. Further, controlling localized SAV decline will contribute to the success of SAV restoration efforts. It was the consensus of the Chesapeake Bay Program's SAV Task Group and I concur that the continued expansion of the Mute Swan population runs counter to the Vital Habitat Protection and Restoration Section of the Chesapeake Bay Agreement (Chapter 3). The goal of Atlantic Flyway Management Plan (2003-2013) is to reduce the Atlantic Flyway population of Mute Swans from 14,000 birds in 2002 to less than 3,000 birds by 2013 (Atlantic Flyway Council 2003). Thus, assuming the target of 2,999 (i.e., $<3,000$ ) birds in 2013, the management plan has suggested $367 \%$ reduction for the Atlantic Flyway, where annual growth rate of Mute Swan population has been 6 \% (Atlantic Flyway Council 2003). Following the target set for the Atlantic Flyway, I suggest that population of Mute Swans in the Chesapeake Bay, Maryland should be brought down from about 3,600 birds in 2002 (Atlantic Flyway Council 2003) to 342 birds by 2013 (Appendix IV). The population level suggested by me matches with the target population suggested by the Maryland DNR, i.e. $<500$ birds (Atlantic Flyway Council 2003). When the State's Mute Swan population was less than 500 birds, adverse ecological impacts and conflicts between people and Mute Swans were negligible (Hindman and Harvey 2004). 
My study showed that flocks, unlike pairs of Mute Swans, caused up to $100 \%$ SAV cover reduction in shallower water (Chapter 3). The study also has revealed that Mute Swans in flocks spent more time feeding than those in breeding pairs and swans in larger flocks spent more time feeding than those in smaller flocks (Chapter 2). Flocks, especially larger ones, are more detrimental to SAV in the Bay as compared to pairs (Cobb and Harlan 1980, Chapter 2). Pairs defend large territories during breeding seasons, and therefore, damage to SAV beds in breeding territories is likely negligible (Fenwick 1983), which further indicates that pairs are less detrimental to SAV beds as compared to the flocks. Flocks are relatively more harmful also due to the fact that pair bonds may be formed in flocks (Birkhead and Perrins 1986) and thus flocks also are the origin of future population growth (Chapter 2). Thus, considering that flocks are more detrimental to SAV as compared to paired Mute Swans, emphasis must primarily be placed on controlling Mute Swan populations in flocks, and secondarily on pairs (Chapter 2,3). Therefore, management efforts to restore SAV should emphasize removal of adult Mute Swans in flocks, especially larger-ones, rather than concentrating solely on addling eggs. Removal by hunting was successfully used in upper Patuxent River in Maryland to get rid of large numbers of resident Canada Geese (Branta canadensis) and in turn, to reestablish wild rice (Zizania aquatica) to the Patuxent marshes (Haramis 2003). A similar recovery of wild rice in a New Jersey marsh was the result of reducing the goose population by shooting and hazing (Theodore Nichols, New Jersey Division of Fish and Wildlife, personal communication). In the same way, lethal control of Mute Swans would be beneficial for recovery of SAV in the Chesapeake Bay. 
I recommend that Mute Swan impacts and control should not only be considered in the frame-work of SAV protection and management, but the larger frame-work of evaluating and controlling the impact of invasive species on native ecosystems. Though exotic species constitute one of the most serious challenges to native flora and fauna of the US, most exotic bird species in North America are poorly studied (Temple 1992). I hope my study can be used as model for other exotic species in different systems.

\section{Future Research}

Future research is needed to cover more localities of the Bay for the exclosure studies in the upper and lower Bay portions. Thus, apart from the mid-Bay portion that I covered in this study, it would be useful to establish exclosures and control plots in select localities in the upper and lower Bay and measure percent cover, shoot density, and canopy height in them. The simple design of exclosures, which was developed for my study, can be considered for such futuristic study. This is because the design used in my

study was not only effective in tidal water conditions and against Mute Swans in the Bay, but also relatively cost effective as it cost about $\$ 25$ for a $5 \times 5 \mathrm{~m}$ plot.

With regards to time-and-activity budgets, it would be useful to include nocturnal observations of Mute Swans' activities through focal sampling, as my study was limited to diurnal observations only. Though it is unknown whether or not Mute Swans feed during nocturnal hours in the Bay, it is likely as other species of swans in North America; especially Trumpeter Swans (Cygnus buccinator) feed at night in addition to the day (Henson and Cooper 1994). 
Food-habits analyses should continue to further document the use of SAV and other food items, including corn, by Mute Swans in the Bay (Perry et al. 2004). Thus, future research should involve a diet study, and more importantly, a food selection study, for Mute Swans in the Bay. A diet study (through destructive swan sampling) will provide information regarding diet of Mute Swans in the Bay during the recent time frame. Quantitative data on the diet composition of Mute Swans in pairs and nonbreeding flocks during different seasons (spring, summer, and fall) would be valuable. Therefore, quantitative information on seasonal variation in diet composition, diet variation according to sex and diet difference/similarity vis-à-vis the breeding/nonbreeding phase of the Mute Swans would be available. The amount of specific SAV plants consumed also could be determined.

A food selection study will be useful to determine year-round food selection by breeding and non-breeding Mute Swans in the Bay. It can provide information about preferences of Mute Swans for different species of SAV to fulfill their food requirements. Moreover, preferences for invertebrates as food items also can be revealed. Through gullet content analysis and quadrat/benthic core samples, such a study would enable us to compare the amount of food content (SAV and invertebrate species) consumed with the amount of the respective food resources available at different sites in the Chesapeake Bay. Thus, it will be possible to infer, whether or not the consumption of food resources by Mute Swans in the Bay is proportional to their availability. 


\section{LITERATURE CITED}

Atlantic Flyway Council. 2003. Atlantic Flyway Mute Swan Management Plan 2003-

2013. Atlantic Flyway Council, Laurel, Maryland, USA.

Birkhead, M. E., and C. M. Perrins. 1986. The Mute Swan. Croom Helm, London, UK.

Chesapeake Bay Program. 2004. Preserving and restoring bay grasses. Maryland

Department of Natural Resources. Annapolis, Maryland, USA.

$<$ http://www.chesapeakebay.net/restrtn.htm $>$.

Cobb, J. S., and M. M. Harlan. 1980. Mute Swan (Cygnus olor) feeding and territoriality affects diversity and density of rooted aquatic vegetation. American Zoologist 20:882.

Fenwick, G. H. 1983. Feeding behavior of waterfowl in relation to changing food resources in Chesapeake Bay. Dissertation, Johns Hopkins University, Baltimore, Maryland, USA.

Feral, P. 2004. Nonlethal techniques to reduce animal problems. Pages 52-54 in M. C. Perry, editor. Mute Swans and their Chesapeake Bay Habitats: Proceedings of a Symposium: U. S. Geological Survey, Biological Resources Discipline Information and Technology Report USGS/BRD/ITR-2004-0005.

Haramis, M. G. 2003. Restoring wild rice to the Patuxent River marshes. Patuxent Wildlife Research Center, Laurel, Maryland, USA. $<$ http://www.pwrc.usgs.gov/products/sciencebriefs/SB 36 Haramis science brief.pdf $>$

Henson, P., and J. A. Cooper. 1994. Nocturnal behavior of breeding Trumpeter Swans. Auk 111: 1013-1018. 
Hindman, L. J., and W. F. Harvey. 2004. Status and Management of Mute Swans in Maryland. Pages 11-17 in M.C. Perry, editor. Mute Swans and their Chesapeake Bay Habitats: Proceedings of a Symposium: U. S. Geological Survey, Biological Resources Discipline Information and Technology Report USGS/BRD/ITR-20040005.

Hurley, L. M. 1990. Field guide to the submerged aquatic vegetation of Chesapeake Bay, U. S. Fish and Wildlife Service, Washington, D.C., USA.

Kemp, W. M., W. R. Bynton, R. R. Twilley, J. C. Stevenson, and J. C. Means. 1983. The decline of submerged vascular plants in upper Chesapeake Bay: summary of results concerning possible causes. Marine Technology Society Journal 17:7879.

Markarian, M., and J. R. Lovvorn. 2004. Swan Song? Giving a voice to Mute Swans in the Chesapeake Bay. University of Baltimore School of Law, Baltimore. $<$ http://www.animallaw.info/articles/arus11ubaltjenvtll115.htm $>$

Naylor, M. 2004. Potential impacts of Mute Swans to SAV in Chesapeake Bay. Pages 36-37 in M. C. Perry, editor. Mute Swans and their Chesapeake Bay Habitats: Proceedings of a Symposium: U. S. Geological Survey, Biological Resources Discipline Information and Technology Report USGS/BRD/ITR- 2004-0005.

Orth, R. J., and K. A. Moore. 1983. Chesapeake Bay: An Unprecedented Decline in Submerged Aquatic Vegetation. Science 222:51-53.

Perry, M. C., P. C. Osenton, and E. J. R. Lohnes. 2004. Food habits of Mute Swans in Chesapeake Bay. Pages 31-36 in M. C. Perry, editor. Mute Swans and their Chesapeake Bay Habitats: Proceedings of a Symposium: U. S. Geological Survey, 
Biological Resources Discipline Information and Technology Report USGS/BRD/ITR- 2004-0005.

Reese, J. G. 1980. Demography of European Mute Swans in Chesapeake Bay. Auk 97:449-464.

Stevenson, C. J., C. B. Piper, and N. Confer. 1979. Decline of Submerged Plants in Chesapeake Bay. <http://www.fws.gov/chesapeakebay/savpage.htm>

Temple, S. A. 1992. Exotic birds: a growing problem with no easy solution. Auk 109:395-397. 
APPENDICES 
Appendix I. Mean ( $\pm 1 \mathrm{SE})$ values of Submerged Aquatic Vegetation characteristics in the sampling plots at study sites in Chesapeake Bay, Maryland at the end of growing season of 2003.

Sampling Plot ${ }^{\mathrm{a}}$

\begin{tabular}{|c|c|c|c|c|c|c|c|}
\hline \multirow[t]{2}{*}{ Parameter } & \multicolumn{2}{|c|}{ 2-year Exclosure } & \multicolumn{2}{|c|}{ 1-year Exclosure ${ }^{b}$} & \multicolumn{2}{|c|}{ 2-year Open } & \\
\hline & $\bar{x}$ & SE & $\bar{x}$ & SE & $\bar{x}$ & SE & \\
\hline Percent cover & $46.9 \mathrm{a}$ & 5.4 & $29.9 b$ & 3.1 & $30.9 b$ & 3.3 & $\mathrm{~F}_{2,34}=16.78, \mathrm{P}<0.001$ \\
\hline Density (Shoots/ m²) & $165.7 \mathrm{a}$ & 24.2 & $81.6 b$ & 10.4 & $83.8 \mathrm{~b}$ & 12.0 & $\mathrm{~F}_{2,34}=16.22, \mathrm{P}<0.001$ \\
\hline Height $(\mathrm{cm})$ & $10.4 \mathrm{a}$ & 0.7 & $9.2 \mathrm{a}$ & 1.1 & $8.6 \mathrm{a}$ & 1.1 & $\mathrm{~F}, 34=0.88, \mathrm{P}=0.425$ \\
\hline
\end{tabular}

${ }^{\mathrm{a}}$ The same letters in a row indicate no significant difference in mean $(P>0.05),{ }^{\mathrm{b}}$ Unfenced in 2003. 
Appendix II. Percent cover of Submerged Aquatic Vegetation species at study sites $(n=$ 18), Chesapeake Bay, Maryland, USA at the end of the study (May 2003-August 2004).

Study site Species
Widgeon grass
Horned pondweed

\begin{tabular}{|c|c|c|}
\hline Audubon Sanctuary & 100.00 & 0.00 \\
\hline Bay Shore Road & 100.00 & 0.00 \\
\hline Brannock Bay & 100.00 & 0.00 \\
\hline Claiborn Harbor & 87.01 & 12.99 \\
\hline Covey Point Farm & 100.00 & 0.00 \\
\hline Church Neck Road & 100.00 & 0.00 \\
\hline Haven on Bay & 53.54 & 46.66 \\
\hline Hill Point Cove & 100.00 & 0.00 \\
\hline Hooper Island Road & 100.00 & 0.00 \\
\hline Middle Point Road & 86.70 & 13.30 \\
\hline Osprey Point & 83.34 & 16.66 \\
\hline Partridge Lane & 100.00 & 0.00 \\
\hline Punch Pont Road & 83.02 & 16.98 \\
\hline Ragged Point & 100.00 & 0.00 \\
\hline Tar Bay & 100.00 & 0.00 \\
\hline Todds Point Road & 100.00 & 0.00 \\
\hline Twins Point Road & 100.00 & 0.00 \\
\hline Wades Point Road & 100.00 & 0.00 \\
\hline
\end{tabular}


Appendix III. Procedures in ArcGIS 9.0 that were carried out for spatial modeling.

I. Steps for selecting SAV beds of widgeon grass or eelgrass and adding them as a data layer in ArcMap (refer to the relevant matter on page 111):

From the information and maps provided in SAV distribution report of VIMS, I noted the labels of all beds that are composed of widgeon grass and eelgrass.

$>$ After that, by clicking 'option' button at the bottom of the attribute table (of 'SAV bed' layer), and then by clicking "select by attribute" option, I opened an SQL query table with attributes displayed in it (e.g. bed label, area, perimeter, density etc.).

$>$ I highlighted the field "BEDLABEL" and built an SQL query for it by creating an appropriate expression (e.g., "BEDLABEL" = "A1" OR "BEDLBEL" = "B1" OR "BEDLABEL" = "CA1") and exported the respective data to have a separate layer of the "exported output". I initially renamed the exported layer as "eelgrasswidgeon grass beds", but later renamed it as 'SAV beds with most consumed species'..

II. Steps to add 'Higher (i.e., dense and moderate) cover SAV layer' and Lower (i.e. very sparse and sparse) and to depict level-1 and level-2 SAV areas (refer to the relevant matter on page 112):

I opened attribute table of SAV beds and noted all those fields (rows) which have dense and moderate SAV coverage, b) after that, by clicking "option" button at the bottom of the attribute table and then by clicking 'select by attribute' option, I opened an SQL query table with attributes displayed in it, c) highlighted the field 
"DENSITY" (as this is the term used by Orth et al. 2003 to indicate 4 percent cover classes) and built an SQL query for it by creating an appropriate expression (i.e., "DENSITY" >=3) and exported the respective data to have a separate layer of the "exported output". I renamed the exported output layer as "higher cover SAV".

In the same way, I added 'lower cover SAV' layer using expression "DENSITY"> = 1 in SQL query table.

When I intersected the layer of high cover SAV with the data layer of "high threat SAV areas' in the existing maps, I could add and depict SAV bed area with most important SAV species from the view point of Mute Swans' food, and also having higher coverage (i.e., level-1 high threat SAV area).

Similarly, when I intersected 'lower cover SAV' layer with the data layer of 'high threat SAV areas' in the existing maps, I could add and depict SAV bed area with most important SAV species from the view point of Mute Swans' food, but having lower coverage (i.e. level-2 high threat SAV area).

III. Steps to import bathymetry layer (in the form of DEMs) to ArcMap and selecting 0 $\mathrm{m}$ and $1 \mathrm{~m}$ depth contours (refer to the relevant matter on page 112)

Within Arc Toolbox, looked for the 'Conversion Tool' option, b) under this option, selected the sub-option called 'to raster' and further, in this sub-option, looked for 'DEM to Raster' tool.

Using this tool, I could get a grid called $130 \mathrm{~m}$ in Arc Catalogue. Ultimately from the grid, I created a shape file named 'Estuarine Bathymetry' depicting contours (e.g. $0,-1,-2$ etc.) in the Bay using 'Surface Analysis' option in Spatial Analyst extension of the ArcMap. 
Opened the attribute table related to 'Estuarine Bathymetry' layer in the table of contents.

By clicking 'option' button at the bottom of the attribute table, and then by clicking 'select by attribute' option, I opened SQL query table with attributes displayed in it (e.g. FID, CONTOUR, LENGTH ETC).

I highlighted 'Contour' option and double-clicked it. I further selected only the contours representing $0 \mathrm{~m}$ and $1 \mathrm{~m}$ depth by building the expression "CONTOUR" $=0$ and "CONTOUR" $=-1$ and exported the respective contour data to have their own separate shape files. I renamed them as ' $0 \mathrm{~m}$ depth contour' and " $1 \mathrm{~m}$ depth contour' respectively.

IV. Steps to identify, locate, and depict 'urgent protection area' (refer to the matter on page 113):

To take into account the criterion 'a', I added the data layer of 'Mute Swan locations' that provided co-ordinate wise numbers $(1 \leq n \leq 156$; Figure 13$)$ of Mute Swans in the Bay (mainly Maryland portion, partly Virginia portion) to the ArcMap.

Then, using SQL query in the attribute table related to 'Mute Swan locations' data layer, I selected and depicted only those locations that supported large flocks of adult Mute Swans (Figure 14). The layer was added from a file (i.e., 'combined Mute Swan pts.dbf') provided by Maryland DNR (Larry Hindman and Brent Evans, Maryland DNR, personal communication).

Further, to consider the criterion 'b', I made a buffer of $4.25 \mathrm{~km}$ around each location of large flocks of Mute Swans (Figure 15). 
To incorporate the criterion 'c', I made a buffer around $0 \mathrm{~m}$ contour in such a way that it would cover inshore area located within $1 \mathrm{~km}$ distance from the contour (Figure 16).

$>$ After adding all these layers in a single ArcMap file, I intersected each of these layers as also that of high threat (level-1) SAV areas to identify and depict only those portions of SAV beds that is common to each of these layers. I considered the resultant layer as 'urgent protection SAV areas' (Figure 17) as the high density beds of widgeon grass or eelgrass in these areas have been directly exposed to the large flocks of adult Mute Swans that were recorded during the latest Mute Swan population survey conducted by Maryland DNR in September 2005. 
Appendix IV. Determination of target population of Mute Swans in the Chesapeake Bay, Maryland by 2013.

1) Population reduction suggested by Atlantic Flyway (AF) Council for AF

$$
\begin{aligned}
& =[(14,000-2,999) / 2,999] \times 100 \\
& =367 \%
\end{aligned}
$$

(Note that we have considered 2,999 swans as this is the largest possible swan population that is lesser that 3,000 swans suggested by Atlantic Flyway Council).

2) Note that annual population growth rate for AF is $6 \%$ (AF Council 2003).

For Chesapeake Bay, where annual growth rate of Mute Swan population is $15.6 \%$ (Maryland DNR 2001), the population should be reduced by [(15.6)/6] x $367=954 \%$.

3) Considering the population level of 2002 (i.e., 3,600 birds) in the Chesapeake Bay, and the target population reduction of $954 \%$ in Mute Swan population , the target Mute Swan population $\left(\mathrm{MSP}_{\mathrm{t}}\right)$ in Chesapeake Bay by 2013 can be calculated as follows:

$$
\begin{array}{r}
{\left[\left(3,600-\mathrm{MSP}_{\mathrm{t}}\right) / \mathrm{MSP}_{\mathrm{t}}\right] \times 100=954} \\
\text { Therefore, } \mathrm{MSP}_{\mathrm{t}}=342
\end{array}
$$

Thus, it is recommended to reduce the population of Mute Swans to 342 individuals by 2013. 